\title{
GEOTHERMAL R\&D PROGRAM FY 1988 PROJECT SUMMARIES
}

\author{
OCtober, 19898
}

\author{
Prepared for: \\ U.S. Department of Energy \\ Geothermal Technology Division
}

Under Contract: DE-AC01-86CE-30844

\section{Prepared by:}

\author{
Meridian Corporation \\ 4300 King Street \\ SUITE 400 \\ Alexandria, VA 22302
}




\section{DISCLAIMER}

This report was prepared as an account of work sponsored by an agency of the United States Government. Neither the United States Government nor any agency Thereof, nor any of their employees, makes any warranty, express or implied, or assumes any legal liability or responsibility for the accuracy, completeness, or usefulness of any information, apparatus, product, or process disclosed, or represents that its use would not infringe privately owned rights. Reference herein to any specific commercial product, process, or service by trade name, trademark, manufacturer, or otherwise does not necessarily constitute or imply its endorsement, recommendation, or favoring by the United States Government or any agency thereof. The views and opinions of authors expressed herein do not necessarily state or reflect those of the United States Government or any agency thereof. 


\section{DISCLAIMER}

Portions of this document may be illegible in electronic image products. Images are produced from the best available original document. 


\section{ACKNOWLEDGEMENTS}

This document is the result of the collective efforts of the U.S. Department of Energy's Geothermal Technology Division (GTD) and staff of Meridian Corporation. Special appreciation is extended to Ralph Burr, Allan Jelacic, and David Lombard of GTD for their valuable guidance during the formative stages of this document. Individual GTD Program Managers and the Project Managers at the various national laboratories and research institutions are also acknowledged for their input and assistance. This document was edited by James Kupar and Deepak Kenkeremath; principal contributors included Fadia Farrell and Mamo Haile-Mariam of the Meridian Corporation. Special thanks go to Kelly Poe and Claudia MacDonnell for their efforts in document production. 
The Geothermal Technology Division of the U.S. Department of Energy is the lead Federal organization charged with the research and development of technologies to economically exploit the nation's vast geothermal resources. The Geothermal Technology Division (GTD) conducts a discrete portfolio of high-risk, high-payoff R\&D projects in concert with U.S. industry's near-, mid-, and long-term needs. The objective of the Geothermal R\&D Program: - FY 1988 Project Summaries is to provide a "snapshot" in time of the on-going R\&D projects within GTD. The Geothermal R\&D Program - FY 1988 Project Sumaries highlights each individual project/contract performed by national laboratories or under contract by industrial, academic and other research institutions involved in GTD-funded geothermal energy technology development. It is designed to be an easily accessible reference that can inform the U.S. geothermal industry and other interested parties of the technological advances and progress achieved in the DOE Geothermal program, as well as to describe the thrust of the current R\&D directions. The document also can be used to inform industry of potential technology transfer opportunities and future R\&D needs.

The document contains two sections: 1) A brief program overview including the organizational structure and the outline of program funding; 2) Individual program component descriptions and individual project summary sheets for the FY88 Geothermal Research and Development Program. Appendix $A$ is a directory of DOE HQ/GTD, Field Offices, and national 1 aboratories managers involved in the Program, and a list of current contractors. Appendix B lists task names and associated projects and managers. 


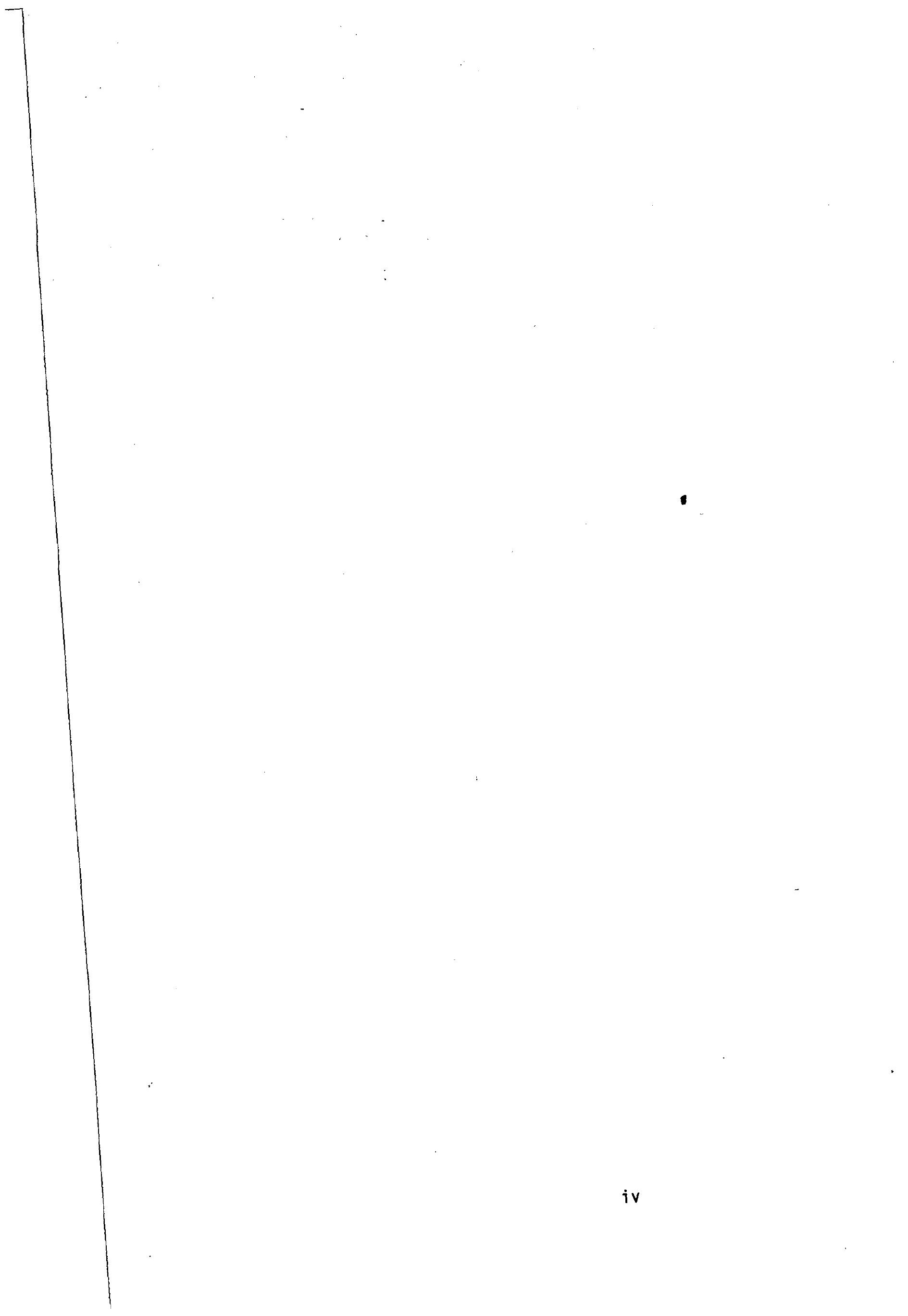




\section{TABLE OF CONTENTS}

Page

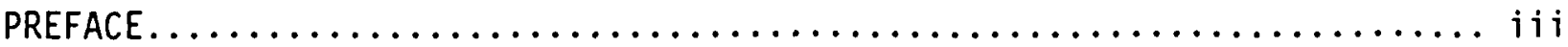

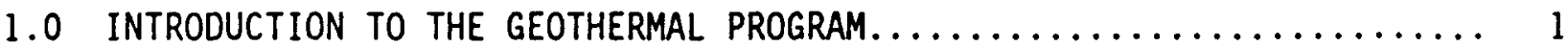

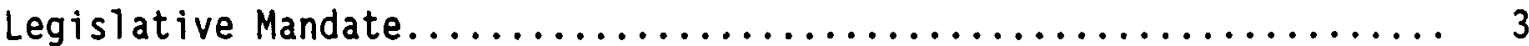

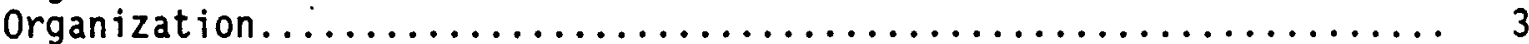

Definition of Terms and Program Structure................. 5

Geothermal Research Funding......................... 5

2.0 HYDROTHERMAL RESEARCH PROGRAM DESCRIPTIONS ............... 11

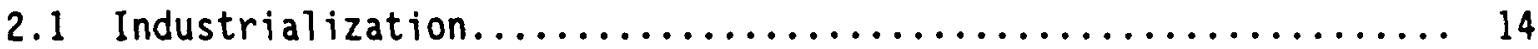

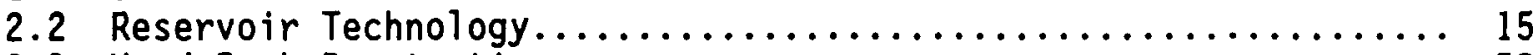

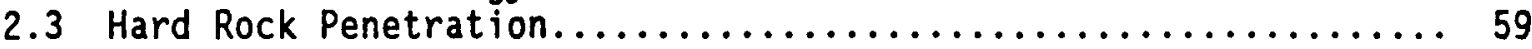

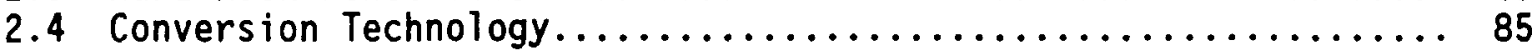

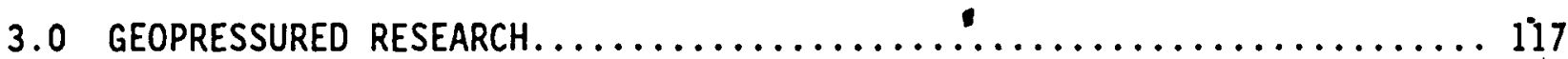

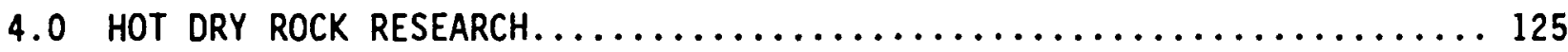

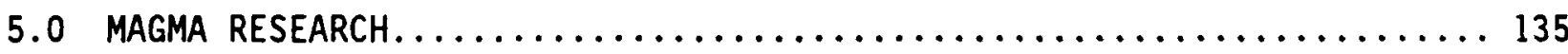

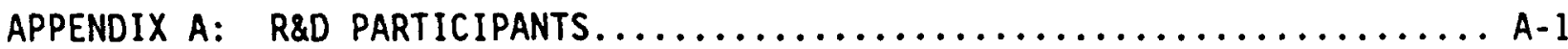

APPENDIX B: TASK NAMES $\ldots \ldots \ldots \ldots \ldots \ldots \ldots \ldots \ldots \ldots \ldots \ldots \ldots \ldots \ldots \ldots \ldots$ 


\section{SECTION 1.0 \\ INTRODUCTION TO \\ THE GEOTHERMAL PROGRAM}



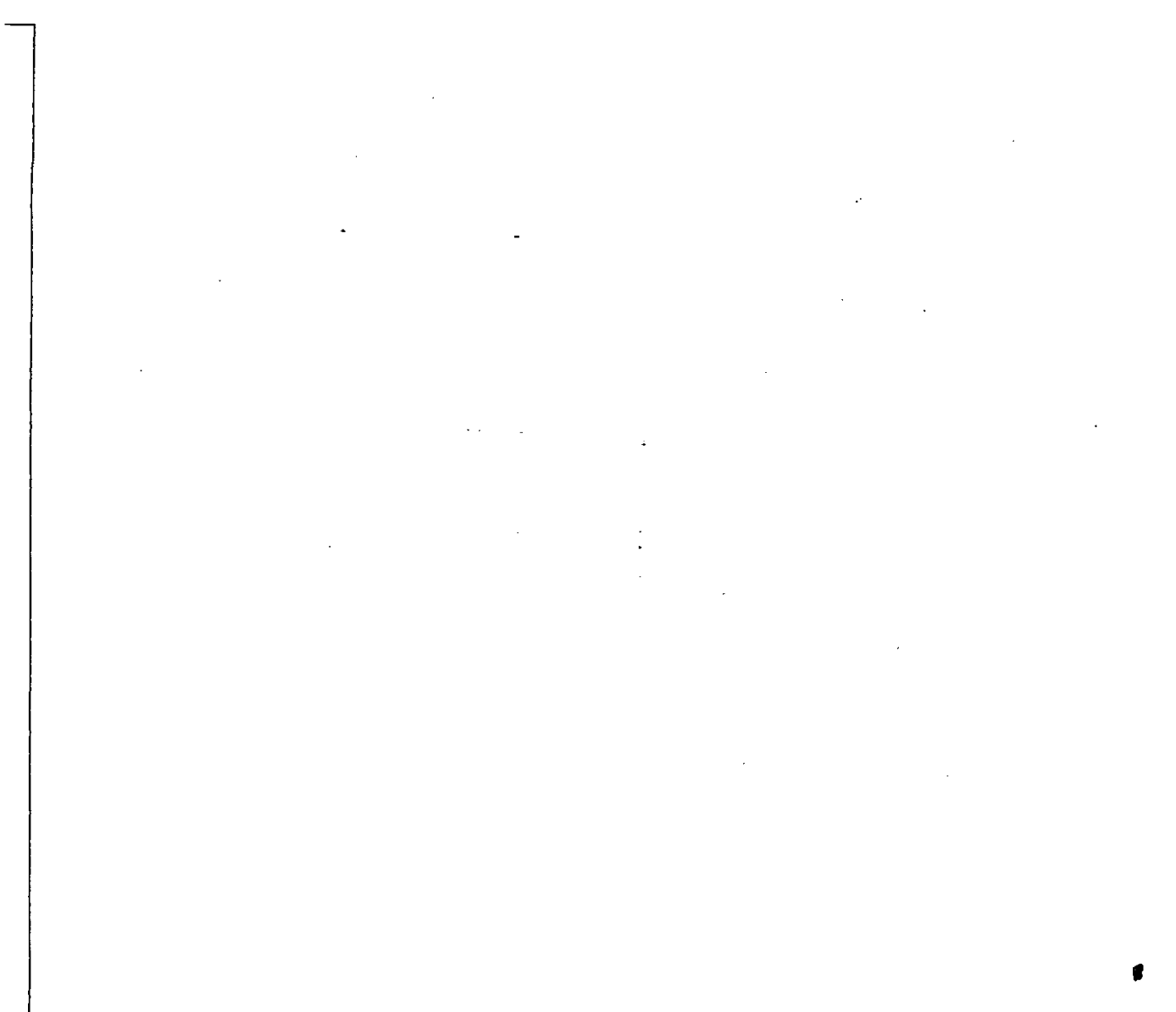


\subsection{PROGRAM OVERVIEW}

Legislative Mandate

Organization
The Geothermal Research and Development Program was created in 1974 by the Geothermal Energy Research, Development, and Demonstration (RD\&D) Act.

The Atomic Energy Commission (AEC) had been given an earlier mandate from Congress to conduct geothermal research and development, as had the National Science Foundation. While some ongoing geothermal R\&D activities had their origins within those two agencies, the RD\&D Act made the first "national commitment... to dedicate the necessary financial resources and enlist the cooperation of the private and public sectors in developing geothermal resources..."

The lead responsibility for coordinating and managing the Federal geothermal R\&D program was passed to the Department of Energy (DOE) when it was created in 1977 and is implemented by the Geothermal Technology Division.

Exhibit 1 shows the organizational structure of DOE's Office of Conservation and Renewable Energy (CE). The Geothermal Technology Division (GTD) lies within the Office of Renewable Energy Technologies (ORET). ORET in turn reports to the Deputy Assistant Secretary for Renewable Energy (DAS/RE) under the overall guidance from the Assistant Secretary for Conservation and Renewable Energy (AS/CE).

The overall strategy and objectives of GTD are contained in the Multi-Year Plan, which discusses the R\&D effort and major milestones for the next five year period. Detailed information on the annual objectives and accomplishments of the research and development efforts of GTO are disseminated through the Division's Annual Operating Plan (AOP). 
Exhibit 1.

OFFICE OF CONSERVATION AND

RENEWABLE ENERGY

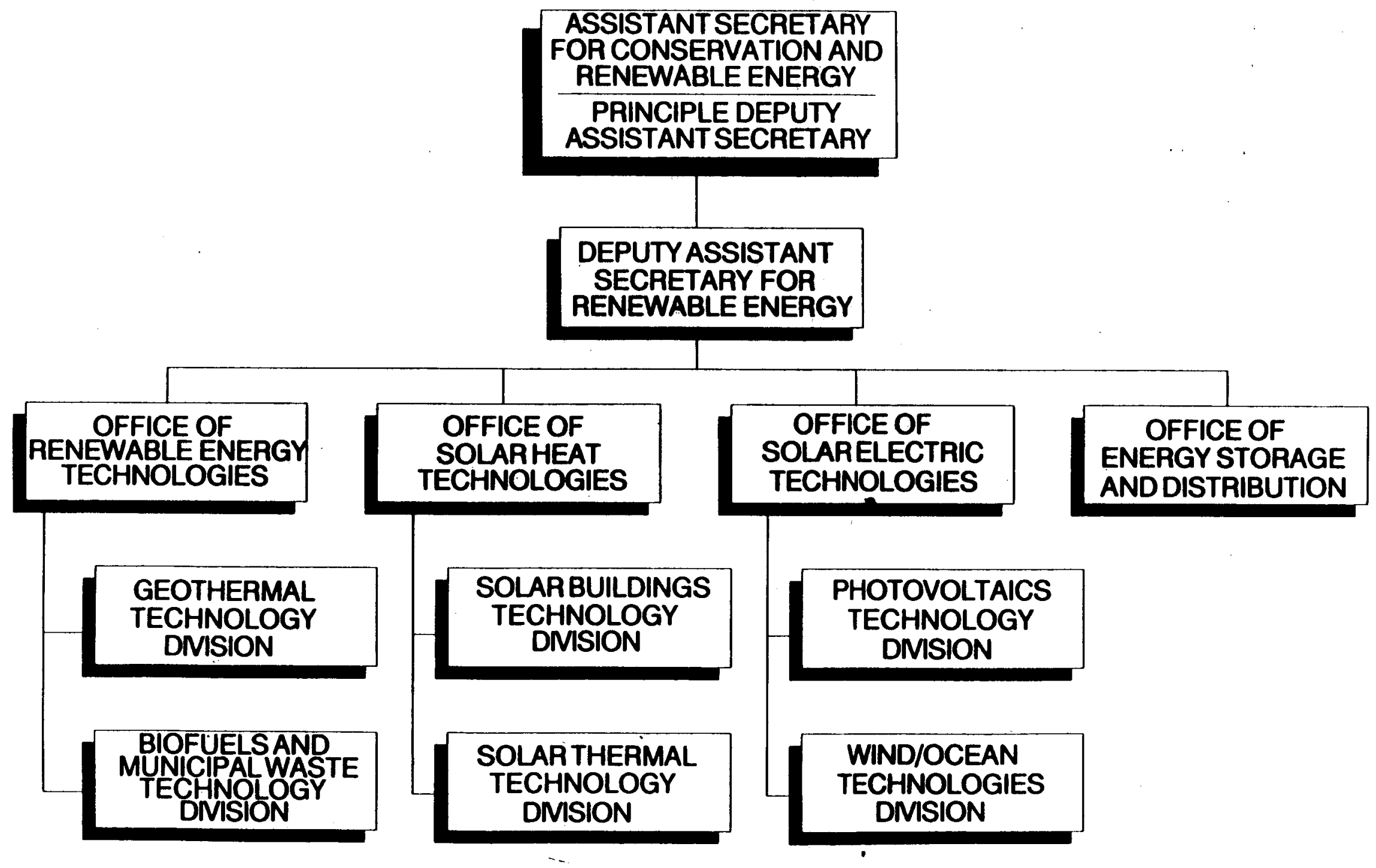

$\infty$ 
Definition of Terms and Program Structure
Geothermal Research Funding
To ensure proper detail for the individual project summary sheets, the following GTD definitions have been used:

$\underline{T e r m}$

Definition

Program

From a management and organizational perspective, there is only one program -- the Geothermal Research and Development Program-which is managed by the Geothermal Technology Division of DOE.

Category

These are the major divisions of the overall R\&D Program. There are four efforts referred to as categories which parallel the resource types.

Task

Subdivisions of a category, each task is composed of an in-house and/or contracted effort which is . managed by a field organization.

Project Individual efforts, both in-house and under contract, that make up the task and category.

Activity Separate efforts carried out in order to complete a Project.

The hierarchical structure of the Geothermal R\&D Program is illustrated in Exhibit 2. The Program participants, identified in Exhibit 3, and 4, indicate which DOE field offices and national laboratories participate in each Category and Task of the Geothermal R\&D Program.

The funding history of the Department of Energy geothermal research activities is shown below. 
Exhibit 2.

PROGRAM HIERARCHY

GEOTHERMAL R\&D

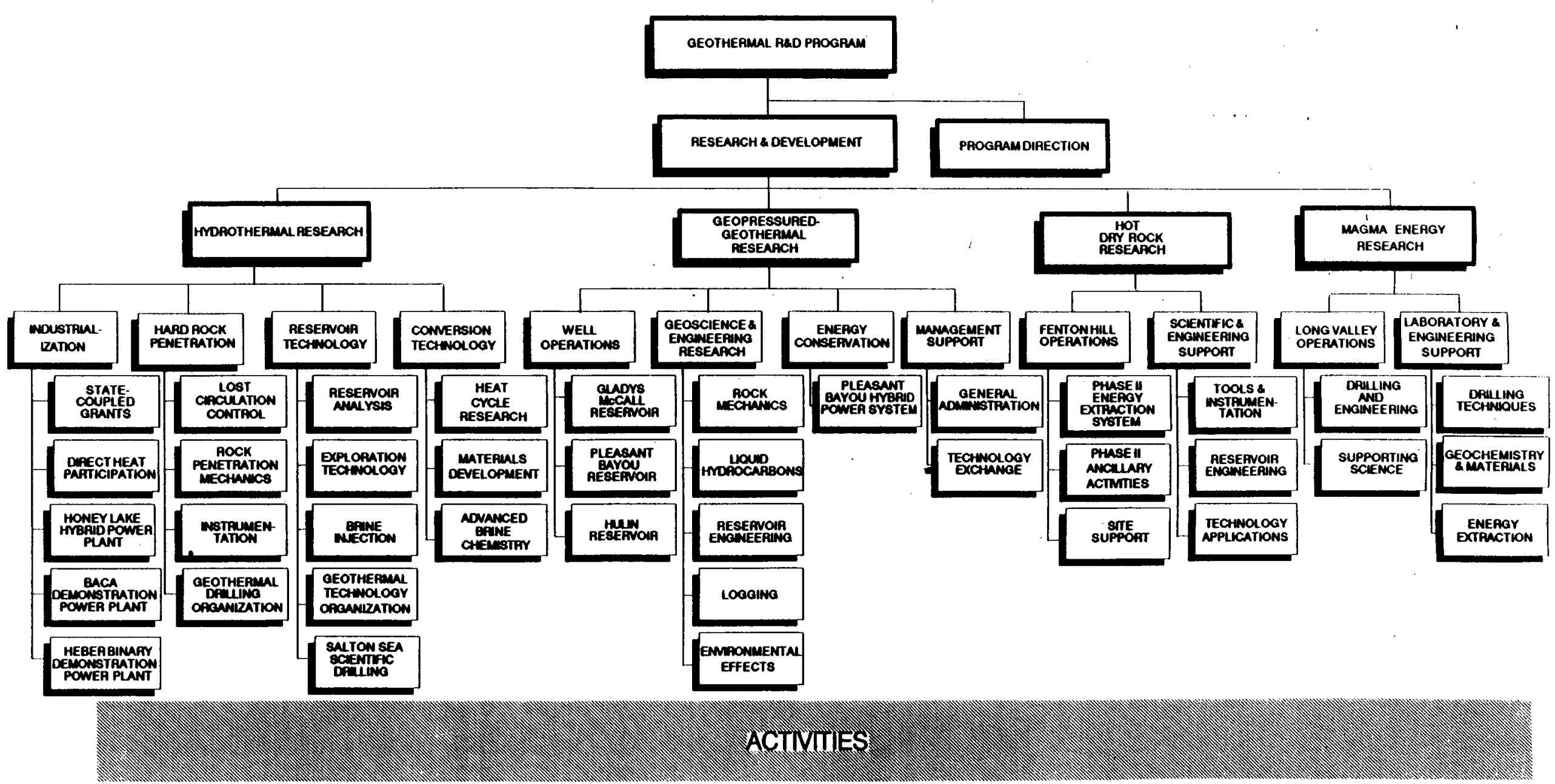


DEPARTMENT OF ENERGY

GEOTHERMAL RESEARCH FUNDING HISTORY (\$1000)

\begin{tabular}{lcccccc}
\hline & $\begin{array}{c}\text { Actual } \\
1984\end{array}$ & $\begin{array}{c}\text { Actual } \\
1985\end{array}$ & $\begin{array}{c}\text { Actual } \\
1986\end{array}$ & $\begin{array}{c}\text { Actual } \\
1987\end{array}$ & $\begin{array}{c}\text { Actual } \\
1988\end{array}$ & $\begin{array}{c}\text { Planned } \\
1989\end{array}$ \\
\hline $\begin{array}{l}\text { Geothermal } \\
\text { Technology } \\
\text { Program Budget }\end{array}$ & 32,615 & 33,511 & 26,495 & 20,830 & 20,935 & 16,456
\end{tabular}

Overview of Projects

Each Project Summary Sheet contains: the title of the Project; the directing organization; the subcontractors; the point of contacts; recent funding; contract period; objectives; tasks; accomplishments; milestones; and titles of major topical reports. 
Exhibit 3.

GEOTHERMAL R\&D PROGRAM PARTICIPANTS

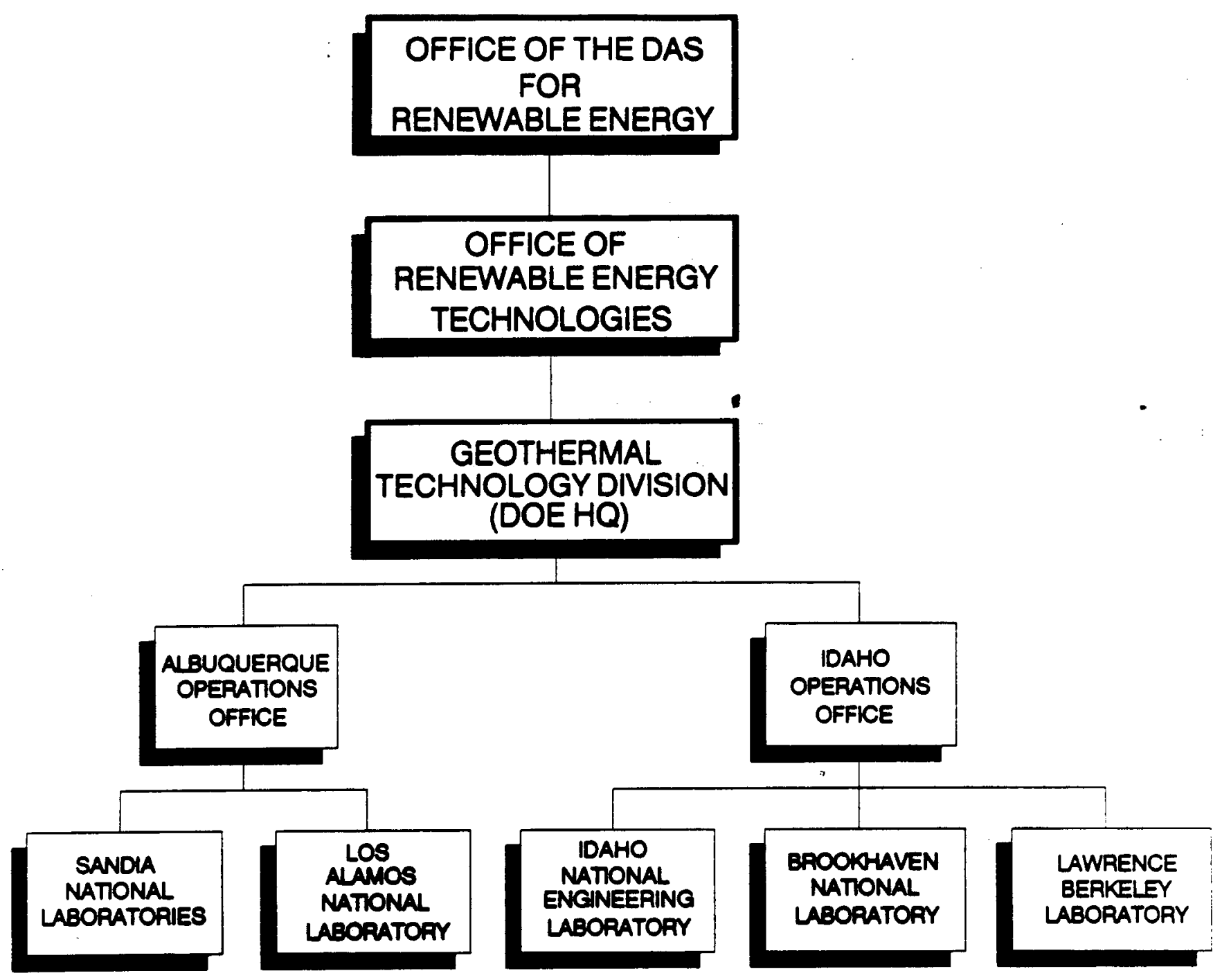


Exhibit 4. DOE OPERATIONS OFFICE AND NATIONAL LABORATORY PARTICIPATION IN THE GEOTHERMAL R\&D PROGRAM

\begin{tabular}{|c|c|c|c|c|c|c|c|}
\hline \multirow{2}{*}{$\begin{array}{l}\text { CATEGORY/ } \\
\text { TASK }\end{array}$} & \multicolumn{2}{|c|}{ OPERATIONS OFFICE } & \multicolumn{5}{|c|}{ NATIONAL LABORATORIES } \\
\hline & ALO & IDO & BNL & INEL & LBL & LANL & SNL \\
\hline \multicolumn{8}{|c|}{ HYDROTHERMAL } \\
\hline \multicolumn{8}{|l|}{$\begin{array}{l}\text { Reservoir } \\
\text { Technology }\end{array}$} \\
\hline \multicolumn{8}{|l|}{$\begin{array}{l}\text { Hard Rock } \\
\text { Penetration }\end{array}$} \\
\hline \multicolumn{8}{|l|}{$\begin{array}{l}\text { Conversion } \\
\text { Technology }\end{array}$} \\
\hline \multicolumn{8}{|c|}{ GEOPRESSURED } \\
\hline \multicolumn{8}{|c|}{ HOT DRY ROCK } \\
\hline MAGMA & & & & & & & \\
\hline
\end{tabular}

KEY

- Responsible Field Office

ResponsibleNational Laboratory

Participant
OPERATIONSOFFICES

$$
\begin{aligned}
& \text { ALO -- Albuquerque } \\
& \text { (Field Management Only) }
\end{aligned}
$$

IDO -- Idaho
NATIONALLABORATORIES

BNL -- Brookhaven National Laboratory

INEL - Idaho National Engineering Laboratory

LBL -- Lawrence Berkeley Laboratory

LANL -- Los Alamos National Laboratory

SNL .- Sandia National Laboratories 


\section{SECTION 2.0}

\section{HYDROTHERMAL RESEARCH \\ PROGRAM DESCRIPTIONS}

$\bullet$ 


\subsection{Hydrothermal Research Program Descriptions}

Description

The hydrothermal research category concentrates on improving technology associated with generating electricity from geothermal resources, especially liquid-dominated, moderate-temperature resources. Geothermal technology for lowtemperature, direct-heat uses appears not to require a special research effort al though many research tasks for hydrothermal electric systems have applications to direct-heat use.

The objective for hydrothermal research is to reduce the life-cycle cost of producing electricity from liquid-dominated, moderate- and high-temperature hydrothermal resources by today's standards 25 to 35 percent by 1992.

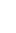




\subsection{InDUSTRIALIZATION}

Status

No new activities have been initiated, so all work is by carry-over funding.

Description

This task area supports ongoing reservoir studies in various states and provides technical assistance for direct heat project. 


\subsection{RESERVOIR TECHNOLOGY}

Status

Description
The three tasks include:

a. Reservoir Analysis: Industry is using DOEdeveloped reservoir characterization techniques, but improvements are needed. A major impediment is the lack of reliable techniques for locating and mapping fractures.

b. Brine Injection Technology: Injection is practiced by virtually all power plant operations, but industry remains concerned about reservoir cooling due to insufficient knowledge on siting injection wells. Removal of solids prior to injection creates large amounts of sludge for which hazardous waste disposal is required.

c. Exploration Technology: Methods for locating and defining masked hydrothermal systems in young volcanic provinces are being developed. Although many geophysical techniques are promising, none have proven to be effective for locating hydrothermal systems in regions with abundant precipitation.

Reservoir analysis research is designed to improve the techniques for characterizing reservoirs and mapping fractures. Several engineering techniques are being analyzed and refined to determine reservoir parameters, map reservoir boundaries and fractures, identify reservoir processes, and characterize boundary conditions. Reservoir modeling techniques are being improved to incorporate actual geothermal fluid properties in current computer codes.

Geothermal geoscience technologies were initially adapted from petroleum and mining industry exploration methods. In order to ensure prudent development decisions, better methods are needed for characterizing hot water reservoirs and predicting their behavior under both production and injection conditions.

Better reservoir definition is critical to obtaining reasonable-cost, long-term financing 
for facilities that will provide a 20- to 30-year supply of energy. Application of the geosciences in conjunction with exploratory drilling and production testing has been very successful in characterizing hydrothermal areas such as the Imperial Valley and Cerro Prieto in Mexico.

The development and exploitation of a geothermal reservoir depends on an understanding of the reservoir's properties. The overali hydrogeological characteristics of the reservoir (e.g., lithology, structure, boundaries, fractured flow versus porous media, recharge) largely control the circulation of the geothermal fluids under natural conditions and during exploitation. The thermodynamic and geochemical properties of the formation fluids and mineral characteristics will gvern, in large part, the processes occurritig in the reservoir; however, the management of the energy resources (e.g., well locations and completions, rates of mass production and injection) is also an important factor controlining these processes, ultimately affecting the economic life of a geothermal field.

The primary focus of the Geothermal Program's R\&D on reservoir analysis through FY 1987 has been:

- Characterization and mapping of reservoir parameters, processes, and spatial dimensions;

- Monitoring and prediction of reservoir changes during production lifetime;

- Fracture detection and mapping; and

- Field case studies.

The ability to control thermal and chemical effects of fluids injected into producing hydrothermal reservoirs is an established priority of the geothermal industry. Injection of spent geothermal fluid is required to maintain pressure in the producing zone of the reservoir and is usually dictated by environmental regulations. Injection plans must avoid premature breakthrough of cool fluids to producing wells. The Program places major emphas is on research which the geothermal industry has stated that it cannot perform. 
Brine injection technology R\&D addresses industry's needs by developing techniques to predict the chemical, thermal, and hydrologic effects of injection. These research activities will lead to more effective predictions of the effects of injection on a producing reservoir and efficient methods of heat extraction.

Existing geothermal exploration technologies leave a great many questions to be answered in their application to young volcanic environments. Some high-silica volcanic environments are believed. to contain active subsurface magma chambers which would provide a heat source for geothermal systems. It is difficult with available technologies to locate and evaluate geothermal systems in young-volcanic environments. The objective of exploration technology is to develop analytical and interpretive tools for industry to use in locating and evaluating geothermal reservoirs within young volcanic regions.

During the past two years, this task has concentrated on the Cascades region of northwest U.S. where geothermal exploration is made difficult by shallow, cool ground water overlaying hot reservoirs. DOE has supported costshared research with industry in selected areas. Downhole geophysical well logs have been obtained from the projects, and the physical and chemical properties of the core retrieved have been analyzed. These data are being compared to surface geological, geochemical, and geophysical data for the purpose of developing and verifying new analytical tools and testing existing tools. Results to date indicate that more exact methods are needed for use in conjunction with surface electrical geophysical surveys because some of the low-resistivity zones found from surface surveys correlate with low-temperature alteration of volcanic rocks. A second important result is the measurement at three sites of the depth to which cold surface water circulates, which is the minimum depth that industry must drill to obtain reliable heat-flow measurements. 
Task: Reservoir Technology

GTo Manager: Marshall J. Reed

\begin{tabular}{|c|c|}
\hline \multicolumn{2}{|c|}{ Predictive Modeling of Reservoir Behavior } \\
\hline $\begin{array}{l}\text { Directing Organization: } \\
\text { Idaho Operations Office } \\
785 \text { DOE Place } \\
\text { Idaho Falls, ID } 83402\end{array}$ & $\begin{array}{l}\text { Contractor: } \\
\text { Lawrence Berkeley Laboratory } \\
\text { Earth Science Div., Bidg. } 50 E \\
\text { Berkeley, CA } 94720\end{array}$ \\
\hline $\begin{array}{l}\text { Project Manager: } \\
\text { Isamu Aoki }\end{array}$ & $\begin{array}{l}\text { Principal Investigator: } \\
\text { Marcelo } \mathrm{J} \text {. Lippmann }\end{array}$ \\
\hline $\begin{aligned} \text { Telephone: (208) } & 526-0583(\mathrm{Com}) \\
& 583-0583 \text { (FTS) }\end{aligned}$ & $\begin{aligned} \text { Telephone: (415) } & 486-5035 \text { (Com) } \\
& 451-5035 \text { (FTS) }\end{aligned}$ \\
\hline Contract Number: AC02-7.6SF00098 & Contract Period: 10/17/83-Open \\
\hline Contract Funding: FY 88 & \\
\hline
\end{tabular}

-

Description:

Develop modeling techniques for simulating the response of geothermal systems to different reservoir management programs, and to evaluate the generating capacity and longevity of these systems.

Activities/FY88 Milestones:

Develop a multi-feed zone wellbore simulator

Complete report on comparison of reservoir evaluations based on porous versus fractured medium representations

Further enhance numerical modeling capabilities for fluid and heat flow at conditions near the critical: point of water, and for flow in fractured media

Carry out modeling studies of the Cerro Prieto and Los Azufres geothermal systems.

\section{Accomplishments to Date:}

Developed new numerical capabilities to study flow in fractured and porous media reservoirs, and to deal with the extreme nonlinearities of near-critical flows

Demonstrated the usefulness of computer modeling techniques in evaluating the impact of different production/injection scenarios on the short- and long-term behavior of geothermal systems 
Developed methodologies to integrate geological, geophysical, geochemical and reservoir engineering data to establish the hydrogeologic regime in hydrothermal systems before and during exploitation.

\section{Major Reports to Date:}

Bjornsson, G., and Bodvarsson, G. S., 1987, "A Multi-Feedzone Wellbore Simulator". Geothermal Resources Council Trans., Vol. 11, pp. 503-507, LBL-23723.

Bodvarsson, G. S., 1988, "Reservoir Development Strategy for Hot Water Reservoirs with Emphasis on Reservoir Modeling," Geothermal Resources Council Bulletin, Vol. 17, No. 4, pp. 69-90.

Bodvarsson, G. S., Benson, S. M., Sigurdsson, 01 , Stefansson, V., and Eliasson, e. T., 1984, "The Krafla Geothermal Field, Iceland: 1. Analys is of Well Test Data," Water Resour. Res., Vol. 38, No. 10, Pp. 1007-1021, LBL-18268.

Bodvarsson, G. S., Pruess, K., Stefansson, V., Bjornsson, S., and 0jiambo, S. B., 1987, "The East 0lkaria Geothermal Field, Kenya: 1. History Match with Production of Pressure Decline Data," Jour. Geophys. Res., Vol. 92, No. B1,. pp. 521-539, LBL-20098.

Bodvarsson, G. S., Pruess, K., Stefansson, V., Bjornsson, S., and 0jiambo, s. B., 1987, "The East 01karia Geothermal Field, Kenya: 2. Predictions of Well Performance and Reservoir Depletion," Jour. Geophys. Res., Vol. 92, No. Bl, Pp. 541-554, LBL-20099.

Bodvarsson, G. S. Mess, K., Stefansson, V., Bjornsson, S., and 0jiambo, S. B., 1985, "A Summar: Modeling Studies of the East 01karia Geothermal field, Kenya," Geotherm. sources Council 1985 International volume, pp. 295-301, LBL-19367.

Bodvarsson, G. S., PrL . K., Stefansson, V., and eliasson, e. T., 1984, "The Krafla Geothermal Fie i Iceland: 2. The Natural State of the Reservoir," Water Resour. Res., Vol. 20, No. 11, Pp. 1531-1544, LBL-16203.

Bodvarsson, G. S., Pruess, K., Stefansson, V.: and Eliasson, E. T., 1984, "The Krafla Geothermal Field, Iceland: 3. The Generating Capacity of the Field," Water Resour. Res., vol. 20, No. 11, pp. 1545-1559, LBL-16203.

Cox, B. L., Pruess, K., and McKibbin, R., 1988, "Mathematical Model ing of Near-Critical Convection". Presented at 13th Worshop on Geothermal Reservoir Engineering, Stanford University, January 19-21, 1988.

Halfman, S.E., Lippmann, M. J., Bodvarsson, G. S., 1986, "Quantitative Model of the Cerro Prieto Field". Proc. Eleveth Workshop Geothermal Reservoir Engineering, Stanford, CA, report SGP-TR-92, PD. 127-134 LBL-20523.

Halfman, S. E., Lippmann, M. J., Zelwer, R., and Howard, J. H. : 984 , "Geologic Interpretation of Geothermal Fluid Movement in Cerro Pria:o Field, Baja California, Mexico". Americian Association of Petroleum Geologists Bul1., Vo1. 68, No. 1, pp. 18-30, LBL-15201. 
Lai, C.'H., Bodvarsson, G. S., and Witherspoon, P. A., 1986, "A second-Order Upwind Differencing Method for Non-Isothermal Chemical Transport in Porous Media," Jour. Numerical and Heat Transfer, Vol. 9, pp. 453-471 LBL-19998.

Lippmann, M. J., and Bodvarsson, G. S., 1983, "Numerical Studies of the Heat and Mass Transport in the Cerro Prieto Geothermal Field, "Water Resour. Res., Vol. 19, No. 3, Pp. 753-767, LBL-15509.

Lippmann, M. J., and Bodvarsson, G. S., 1985, "The Heber Geothermal Field, California: Natural State and Exploitation Modeling Studies," Jour. Geophys. Res., Vol. 90, No. Bl, Pp. 745-758, LBL-17572.

Pruess, K., 1988, "SHAFT, MULKOM, TOUGH: A Set of Numerical Simualtors for Multiphase Fluid and Heat Flow," Geotermia, Rev. Mex. Geoenergia, Vol. 4, No. 1, pp. 185-202, LBL-24430.

Pruess, K., and Narasimhan, T. N., 1985, "A Practical Method for Modeling Fluid and Heat Flow in Fractured Porous Media," Soc. Pet. Engr. Jour., Vol. 25, No. 1, Pp. 14-26, LBL-13487.

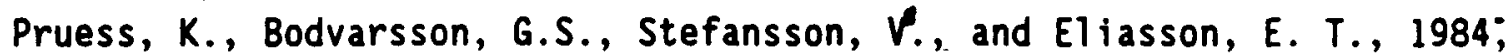
"The Krafla Geothermal Field, Iceland: 4. History Match and Prediction of Individual Well Performance," Water Resour. Res., Vol. 20, No. 11, pp. 1561-1584, LBL-16203.

Pruess, K., Wilt, M. J., Bodvarsson, G. S., and Goldstein, N. E., 1983, "Simulation and Resistivity Modeling of a Geothermal Reservoir with Waters of Different Salinity". Geothermics, Vol. 12, No. 4, Pp. 291-307, LBL-14652.

Ripperda, M., and Bodvarsson, G. S., 1988, "Analysis of Internal Wellbore Flow". Presented at 13th Workshop on Geothermal Reservoir Engineering, Stanford University, January 19-21, 1988.

Samme1, E. A., and Benson, S. M., 1987, "An Analysis of the Hydrologic Effects of Proposed Test Driliing in the Winema National Forest near Crater Lake, Oregon," Geothermal Resources Council Trans., Vol. 11, pp. 293-303 LBL-23721. 


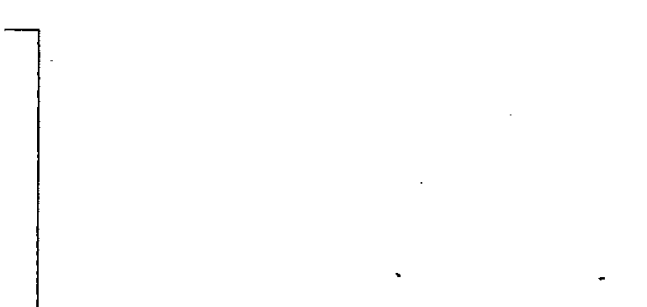

. 
Task: Reservoir Technology

Project: Reservoir Analysis

GTD Manager: Marshall Reed

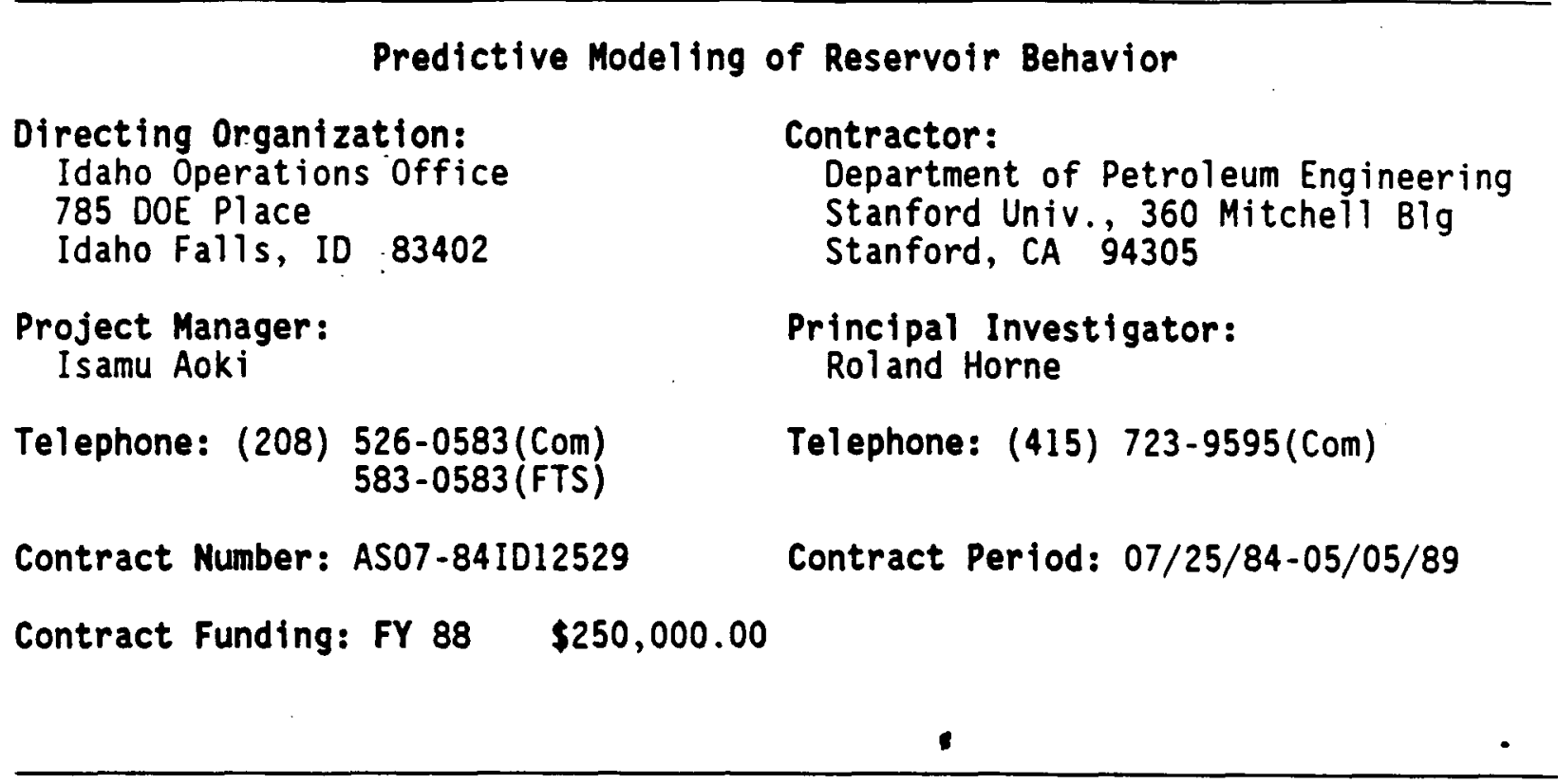

\section{Description:}

Development of modeling capability to predict reservoir performance from well testing and production history.

Activities/FY88 Milestones:

Development of well-testing techniques, and investigation into fundamental properties of reservoir behavior.

\section{Accomplishments to Date:}

Completed set of computer-generated type curves and used them extensively in fieldwide study.

Generated pressure transient models for several new reservoir configurations.

Adopted water influx methodology to geothermal reservoir analysis.

\section{Major Reports to Date:}

Aarstad, Knut, 1987, "Criteria for Determining Times for End of Transient Flow and Start of Pseudosteady State Flow," August 1987. SGP-TR-116

Ambastha, Anil K., and Jon S. Gudmundsson, Jon S., 1986, "Collection and Evaluation of Flowing Pressure and Temperature Data from Geothermal Wells," August 1986. SGP-TR-100 
Beal, Barry A., and Nunes, Craig S., 1984, "Velocity and Gravity Effects in Relative Permeability Measurements," June 1984. SGP-TR-82

Brock, David C., 1986, "Compressibility Effects in Modeling Two-Phase Liquid Dominated Geothermal Reservoirs," June 1986. SGP-TR-102

Dee, John, 1983, "A Reservoir Engineering Analysis of a Vapor-Dominated Gepthermal Field," June 1983. SGP-TR-72

del Socorro Salas, Beatriz, 1986, "Closed Chamber Well Test Including Frictional Effects," August 1986. SGP-TR-104

Demski, Jay A., 1987, "Decline Curve Derivative Analys is for Homogeneous and Composite Reservoirs," June 1987. SGP-TR-110

Economides, Michael, 1983, "Geothermal Reservoir Evaluation Considering Fluid Adsorption and Composition," September 1983. SGP-TR-68

Eipper, Mary E., 1985, "Computer Generation of Type Curves," February 1985. SGP-TR-86

Fox, Glenn, 1984, Linear Boundary Detection Using Pressure Buildup Tests," June 1984. SGP-TR-83

Granados; Eduardo, 1983, "Calcium Carbonate Deposition in Geothermal Wellbores: Miravalles Geothermal Field, Costa Rica," June 1983. SGP-TR-67

Houze, 01 ivier P., 1983, "Infinite conductivity Fracture in a Naturally Fractured Reservoir". June 1983. SGP-TR-73

Hunsbedt, A., Lam, S. T., and Kruger, P1, 1984, "User's Manual for the 1-D Linear Heat Sweep Model," April 1984. SGP-TR-75

Lam, Stephen T., Hunsbedt, Anstein, and Kruger, P., 1985, "Analysis of the Stanford Geothermal Reservoir Model Experiments Using the LBL reservoir Simulator," April 1985. SGP-TR-85

Leaver, Jonathan D., 1986, "A Technical Review of Interference Testing with Application in the Ohaaki Geothermal Field," March 1986. SGP-TR-95

Luetkehans, Jeralyn, 1988, "A Laboratory Investigation of Steam Adsorption in Geothermal Reservoir Rocks," March 1988. SGP-TR-115.

Macias-Chapa, Luis, 1985, "Multiphase, Multicomponent Compressibility in Petroleum Reservoir Engineering," March 1985. SGP-TR-88

Marcou, John Andrew, 1985, "Optimizing Development Strategy for Liquid Dominated Geothermal Reservoirs," July 1985. SGP-TR-90

Mateen, Khalid, 1983, "Slug Test Data Analysis in Reservoirs with Double Porosity Behaviour". September 1983. SGP-TR-70

McLeroy, Priscilla G., 1986, "Transient Pressure Analysis in Strip Reservoirs with Linear Skin Discontinuities," January 1986. SGP-TR-97 
Miller, Mark A., 1983, "Effect of Temperature on 0i1-Water Relative Permeabilities of Unconsolidated and Consolidated Sands," June 1983. SGP-TR-64

01 sen, Gudmund, 1984, "Depletion Modeling of Liquid Dominated Geothermal Reservoirs," June 1984. SGP-TR-80

Ortiz-Ramirez, Jaime, 1983, "Two Phase Flow in Geothermal Wells: Development and Uses of a Computer Code," June 1983. SGP-TR-66

Sageev, Avrami, 1983, "Pressure Transient Analysis of Reservoirs with Linear or Internal Circular Boundaries," June 1983. SGP-TR-65

Saldana-Cortez, miguel-Ange1, 1983, "Orillstem Test Data Analysis Considering Inertial and Frictional Wellbore Effects," November 1983. SGP-TR-69

Simmons, Jeffrey F., 1985, "Closed Chamber Well Test Analys is by Superposition of the Constant Pressure Comulative Influx Solution to the Radial Diffusivity Equation," February 1985. GSP-TR-98

Sinner, Joseph r., 1986, "The Determination of a Volumetric Mixing Law for Use with the Neutron Porosity Logging Tool," June 1986. SgP-Tr-98

Surritt, Brenna L., 1986, "Computer Generation of Type Curves," June 1986. SGP-TR-105

Tavares, Carlos, 1986, "Discharge Analysis of Two-Phase Geothermal Well in Liquid-dominated Reservoirs". SGP-TR-101 


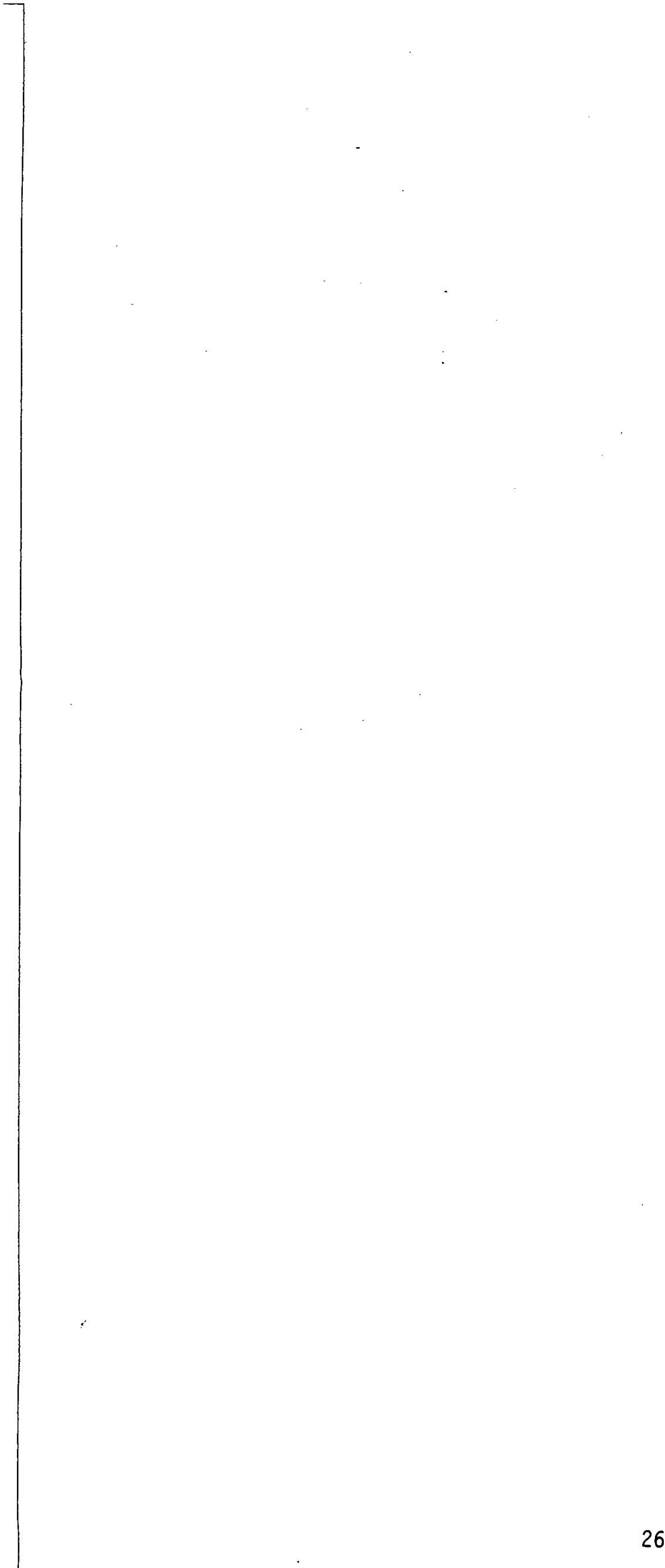


Task: Reservoir Technology

Project: Reservoir Analysis

GTD Manager: Marshall J. Reed

\section{Identification of Reservoir Processes}

Directing Organization:

Idaho Operations office

785 DOE Place

Idaho Falls, ID : 83402

Project Manager:

Isamu Aoki

Telephone: (208) 526-0583(Com)

$583-0583$ (FTS)

Contractor:

University of Utah Research Institute 391 Chipeta Way, Suite $C$

Salt Lake City, UT 84108

Principal Investigator:

P. Michael Wright

Telephone: (801) 524-3439(Com)

588-3439(FTS)

Contract Number: AC07-85ID12489

Contract Period: 10/25/87-Open

Contract Funding: FY $88 \quad \$ 220,000.00$

Description:

Objectives include identification and interpretation of geology, geophysics, geochemistry, and hydrology for the synthesis of knowledge about reservoir processes

\section{Activities/FY88 Milestones:}

Develop hydrogeochemical models of the fracture dominated geothermal systems at Coso, Heber, and Los Azufres from fluid inclusion, fluid chemistry and isotropic data.

Develop methods to interpret borehole breakouts to evaluate in-situ stresses and their origin in geothermal systems. Relate stress fields to fluid flow within the reservoir.

Calibrate thermally-induced transformation of smectite to ilicite for use as a mineral geothermometer.

Use of physical properties laboratory to characterize the electrical resistivity, magnetic susceptibility, and induced polarization response of geothermally-al tered rocks.

Determine the location of major structures at Los Azufres from aeromagnetic data.

Accomplishments to Date:

Demonstrated use of injection-backflow mehtod to investigate scaling process in reservoir. 
Constructed physical properties laboratory for measurement of electrical and magnetic properties of geothermally altered rocks.

Developed hydrogeochemical model for low-permeability geothermal systems applicable to volcanic systems in the Cascade mountain ranges.

Produced detailed model of caprock development in the Salton Sea geothermal field.

Defined alteration mineralogy and structural model of the Valles Caldera geothermal system

\section{Major Reports to Date:}

Adams, M.C., Lemie... M., Moore, J.N., and Johnson, S.D., 1988, "Fluid Chemistry and Hydrolo: "the Heber Geothermal System, California".

Transactions, Geother: Resources Council, in press.

Adams, M.C., and Moore, J. N., 1985, "Geothermal Systems in Mountainous Terrains: An Example for Meager Mountain". American Jour. of Science, v. 287, p. $720-755$.

Ballentyne, J., and Moore, J.M., 1988, "Arsenic Geochemistry in Geothermal Systems". Geochemica et Cosmochemica Acta, v. 52, p. 475-483.

Christensen, 0.D., Capuano, R. C., and Moore, J.N., 1983, "Trace Element Distributions in an active Hydrothemal Systems, Roosevelt Hot Springs Thermal Area, Utah", Journal of Volcanology and Geothermal Research, v. 16, p. 99-129.

Cole, D.R.,1983, "Chemical and isotropic investigations of warm springs associated with normal faults". Journal of Volcanology and Geothermal Research, v. 16, p.65-98.

Hulen, J.B., and Nielson, D.L., 1986, "Hydrothermal Alteration in the Baca Geothermal System, Redondo Dome, Valles Caldera, New Mexico". Journal Geophysical Research, v. 91, p. 1867-1886.

Moore, J.N., and Adams, M.C., 1988, "Evolution of the Thermal Cap in Two Boreholes form the Salton Sea Geothermal System, California". Geothermaics, in press.

Nielson, D.L., and Hulen, J. B., 1984, "Internal Geology and Evaluation of the Redondo Dome, Valles Caldera, New Mexico". Journal of Geophysical REsearch, v. 89, p.8695-8711.

Nielson, D.L., Evans, S.H.,Jr., and Sibbett, B.S., 1985, "Magmatic, Structrual, and Hydrothermal Evolution of the Mineral Mountains Intrusive Complex, Utah". Geological Society of America Bulletin, v.97, p.765-777.

Ross, H.P., and Moore, J.N., 1985, "Geophysical Investigations of the Cove Fort-Sulphurdale Geothermal System, Utah". Geophysics, v. 50, p.1732-1745. 
Task: Reservoir Technology

GTO Manager: Marshall Reed

Project: Reservoir Analysis

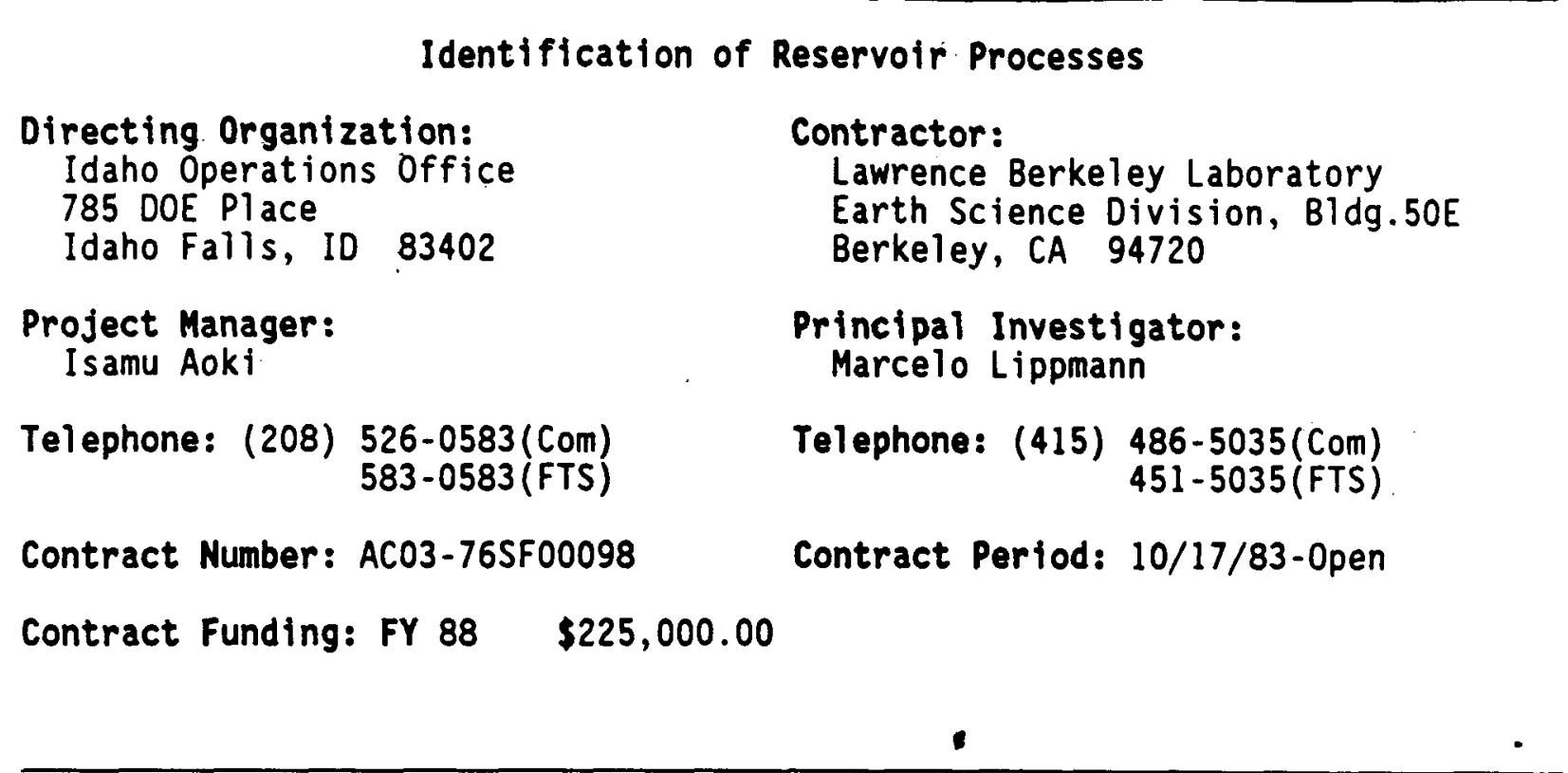

Description:

Analyze and refine techniques for identifying reservoir processes and evaluating their impact on the behavior of hydrothermal systems.

\section{Activities/FY88 M+lestones:}

Prepare report on fluid flow and heat transfer near the critical point of pure water

Analyze field data and model partitioning of oxygen-18 between vapor and liquid phases in geothermal reservoirs

Study the effects of liquid-steam counterflow on well testing data from boiling geothermal reservoirs and evaluate the effects of non-condensible gases in reservoirs with counterflow

Develop an analytical solution for internal flow in geothermal wells

Analyze well test data to identify processes that cause an increase in permeability during the injection of colder brines into geothermal reservoirs.

Complete self-potential resurvey of the East Mesa geothermal field to ascertain whether production/injection-related effects exist Geysers

Carry out high-frequescy seismic monitoring of fluid injection at The 
Accomplishments to Date:

Developed basic understanding of fluid, heat and chemical species transport in permeable (porous and fractured) media

Evaluated the relative importance of different reservoir phenomena (e.g., heat pipe effects, conductive enthalpy enchancement, relative permeability effects) under single-phase (compressed liquid, steam) or two-phase conditions, on the behavior of hydrothermal systems

Carried out field (geophysical and reservoir engineering) studies to test techniques and tools for identifying and quantifying subsurface processes associated with production and injection of geothermal fluids

\section{Major Reports to Date:}

Benson, S.M., and Bodvarsson, G.S., 1986, "Nonisothermal Effects during Injection and Fall off Tests", SPE Formation Evaluation, Vol, 1, No. 1, pp. 53-63, LBL-14270.

Benson, S.M., and Lai, C. H., 1986, "Analysjs of Interference Data in a Highly Heterogeneous and Naturally Fractured Gebthermal Reservoir". SPE Formation Evaluation, Vol. 1, No. 3, Pp. 236-248, LBL-17450.

Benson, S.M., Daggett, J. S., Iglesisas, E., Arellano, V., and Ortiz-Ramirez, J., 1987, "Analysis of Thermally Induced Permeability Enhancement in Geothermal Injection Wells". Proc. Twelfth Workshop Geothermal Reservoir Engineering, Stanford, CA, report SGP-TR-109, Pp. 57-66, LBL-23022.

Bodvarsson, G. S., and Cox, B. L., 1986, "Numerical Studies of Gravity Effects in Two-Phase Reservoirs". Geothermal Resource Council Trans., Vol. 10, pp. 429-436, LBL-21935.

Bodvarsson, G.S., and Gaulke, S. W., 1987, "Effects of Noncondensible Gases on Fluid Recovery in Fractured Geothermal Reservoirs". SPE Reservoir Engineering, Vol. 2, No. 3, Pp. 335-342, LBL-21112.

Bodvarsson, G. S., Cox, B. L., and Ripperda, M. A., 1988, "Effects of Steam-Liquid Counterfiow on Pressure Transient Data from Two-Phase Geotherma] Reservoirs". SPE Reservoir Engineering (in press).

Cox, B. L., and Bodvarsson, G. S., 1986, "Preliminary Studies of Two-Phase Effects on Pressure Transient Data". Proc. Eleventh Workshop Geothermal Reservoir Engineering, Stanford, CA, report SGP-TR-93, PD. 7-14, LBL-21249.

D'Amore, F., and Pruess, K., 1986, "Correlations Between Vapor Saturation, Fluid Composition, and We11 Decline in Larderello". Geothermics, Vol. 15, No. 2, pp. 167-183, LBL-18899.

Gaulke, S. W., and Bodvarsson, G. S., 1987, "Analys is of Pressure, Enthalphy and $\mathrm{CO} 2$ Transients in Well BR21, Ohaaki, New Zeal and". Geothermal Resources Council Trans., Vol. 11, pp. 535-539, LBL 23718. 
Goldstein, N.E., Sasaki, Y. and Wilt, M.J., 1985. "Two-dimensional inversion of resistivity monitoring data from the Cerro Prieto geothermal field". Trans. Geother. Resourc. Council, V.9, pt. II, pp.17-25.

Lippmann, M. J., and Bodvarsson, G. S., 1988, "Convective Heat Transport in Geothermal Systems". Revista Brasileira de Geofisica (in press), LBL-21984.

Mckibbin, R., and Pruess, K., 1988, "Some Effects of Non-Condensible Gas in Geothermal Reservoirs with Steam-Water Counterflow". Presented at 13 th Workshop on Geothermal Reservoir Engineering, Stanford University, January 19-21, 1988.

Narasimhan, T. N., and Goya1, K. P., 1984, "Subsidence Due to Geothermal Fluid Withdrawal". Geol. Soc. Am. Review in Engineering Geology. Vol. VI, pp. 35-48, LBL-10967.

O'Sullivan, M. J., Bodvarsson, G. S., Pruess, K., and Blakeley, M. R., 1985, "Fluid and Heat Flow in Gas-Rich Geothermal Reservoirs". Soc. Pet. Engr. Jour., Vol. 25, No. 2, pp. 215-226, LBL-16329.

Pruess, K., 1985, "A Quantitative Model of Vapor-Dominated Geothermal Reservoirs as Heat Pipes in Fractured Porous Rock". Geothermal Resources Council Trans., Vol. 9, II, Pp. 353-361, LBL-19366.

Pruess, K., Calore, C., Celati, R., and Wu, Y. S., 1987, "An Analytical Solution for Heat Transfer at a Boiling Front Moving through a Porous Medium". Int. Jour. of Heat and Mass Transf. Vol. 30, No. 12, pp. 2595-2602, LBL-22513.

Pruess, K., Celati, C., Calore, C., and Cappetti, G., 1987, "On Fluid and Heat Flow in Deep Zones of Vapor-Dominated Geothermal Reservoirs". Proc. Twelfth Workshop Geothermal Reservoir Engineering, Stanford, CA SGP-TP_109, pp. 89-96, LBL-22810.

Verma, A., and Pruess, K., 1986, "Enhancement of Steam Phase Relative Permeability Due to Phase Transformation Effects in Porous Media". Proc. Eleventh Workshop Geothermal Reservoir Engineering, Stanford, CA, report SGP-TR-93, PP. 223-224,LBL-21027.

Wilt, M.J. and Goldstein, N.E., 1984, "Interpretation of dipole-dipole resistivity monitoring data at Cerro Prieto". Geothermics, V. 13, pp. 13-26. 


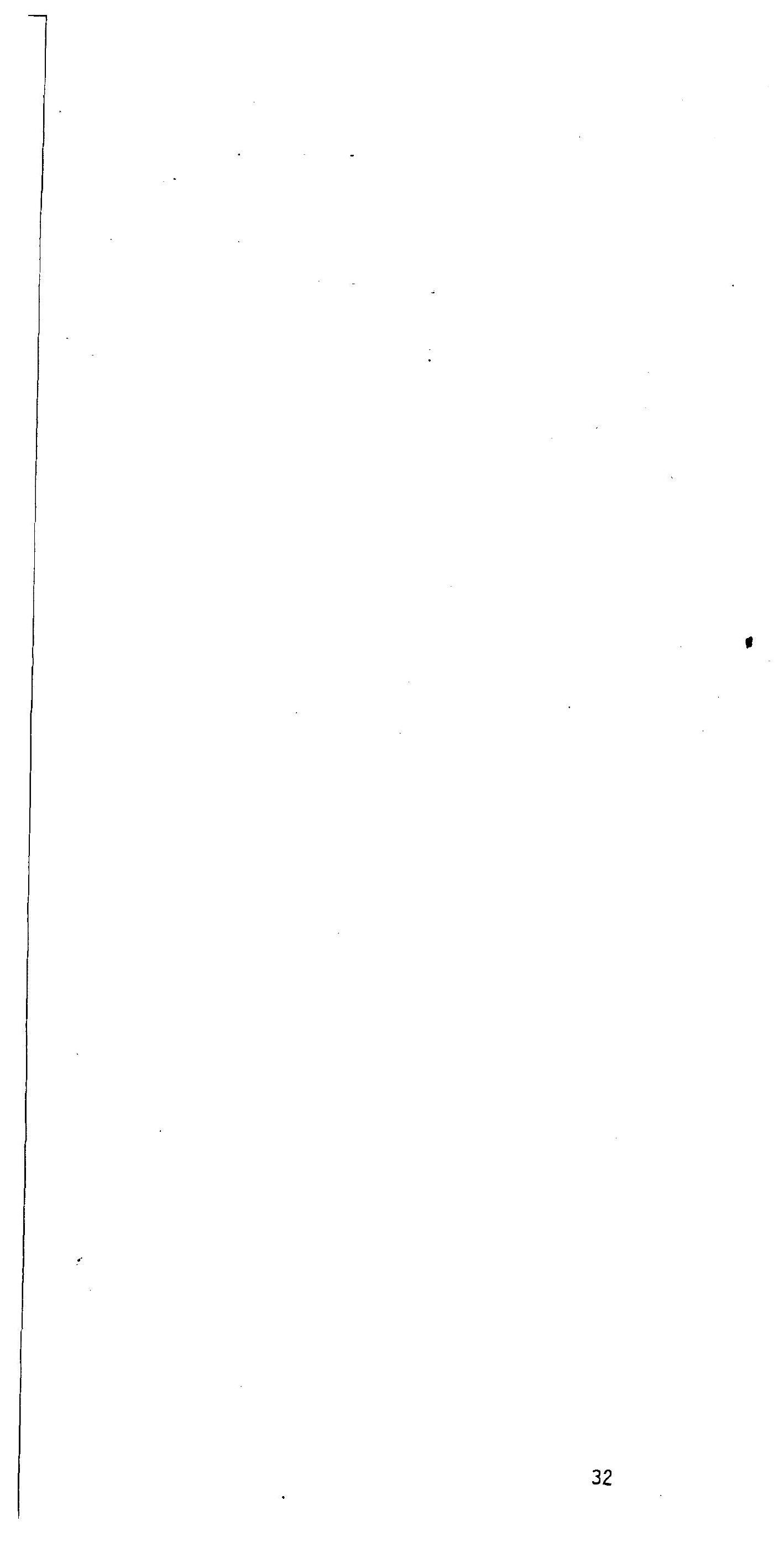


Task: Reservoir Technology

Project: Reservoir Analysis

GTD Manager: Marshal1 Reed

\footnotetext{
Fracture Detection and Mapping

Directing Organization:

Idaho Operations office

785 DOE Place

Idaho Falls, ID : 83402

Project Manager:

Isamu Aoki

Telephone: (208) 526-0583(Com)

583-0583 (FTS)

Contract Number: AC07-85ID12489

Contract Funding: FY $88 \quad \$ 200,000.00$

Contractor:

University of Utah Research Institute 391 Chipeta Way, Suite C

Salt Lake City, UT 84108

Principal Investigator:

P. Michael Wright

Telephone: (801) 524-3439(Com)

$588-3439$ (FTS)

Contract Period: 10/25/87-5/5/90

Description:

The objectives are the development and verification of computer-based methods to evaluate the use of borehole geophysical techniques for locating fractures and permeable zones in geothermal systems. Accomplishment of early objectives lead to design, development, and field testing of instrumentation for surface-to-borehole, borehole-to-surface, and borehole-to-borehole surveys.

\section{Activities/FY88 Milestones:}

Extend numerical model results for borehole arrays.

Complete second stage design for multi-array borehole fracture detection instrumentation.

Construct first generation model of field instrumentation.

Distribute technical reports.

Accompl ishments to Date:

State-of-the-art review completed, evaluated.

Theoretical responses have been determined for the more promising electrical and electromagnetic methods.

Developed algorithms for numerical models and completed numerical calculations for most applicable methods and arrays, results published.
} 
Design completed for multi-method, mu? array borehole geophysical instrumentation.

\section{Major Reports to Date:}

Beasley; C.W., and Ward, S.H., 1986, "Three-dimensional mise-a-1a-masse modeling applied to mapping fracture zones". Geophysics,v.51, p.98-113.

Green, D.J., and Ward, S.H.,1986, "Report on preliminary design for multi-array borehole electrical geophysical method". DOE/SAN 1219623, ESL-TR.

LaBrecque, D.J., and Ward, S.'H., 1988, "The effect of well casing on 3-D interpretation of borehole resistivity data". SEG ann. mtg. ext. abs. (in Press).

LaBrecque, D.J., 1988, "Design of a borehole-to-surface resistivity survey for the mama deep exploration we: '. GRC Trans, v. 12 (in press).

Ross, $\therefore$.P., and Ward, S.H., 1984, "Borehole electrical geophysical methods- $A$ review of the state-of-the-art and preliminary evaluation of the application to fracture mapping in geothermal systems". DOE/SAN/12196-2, ESL Rpt. No. $141,61 \mathrm{p}$.

West, R.C., and Ward, S. H., 1988, "The borehole controlled source audiomagnetotelluric response of a three-dimensional fracture zone". Geophysics, v. 53, p. 215-230.

Wright, P.M., and Ward, S.H., 1986, "Borehole geophysical techniques for defining permeable zones in geothermal systems". Geothermal Resources Council, Trans., v. 10, p. 253-258.

Yang, F.W., and Ward, S. H., 1985, "Short Note: On sensitivity of surface-to-borehole resistivity measurements to the attitude and the dooth to center of a three-dimensional sphe sid". Geophysics, v. 50, p.1173-1178

Yang, F.W., and Ward, S.H., 1985, "Single borehole and cross-borehole resistivity anomalies of thin ellipsoids and spheroids". Geophysics, $v .50$, p.637-655.

Zhao, J. X., Rijo, L., and Ward, S. H., 1986, "The effects of geologic noise on cross-borehole electrical surveys". Geophysics, v. 51, p. 1978-1991. 
Task: Reservoir Technology

Project: Reservoir Analysis

GTD Manager: Marshall Reed

\begin{tabular}{|c|c|}
\hline \multicolumn{2}{|c|}{ Fracture Detection and Mapping } \\
\hline $\begin{array}{l}\text { Directing Organization: } \\
\text { Idaho Operations Office } \\
785 \text { DOE Place } \\
\text { Idaho Falls, ID }: 83402\end{array}$ & $\begin{array}{l}\text { Contractor: } \\
\text { Lawrence Berkeley Laboratory } \\
\text { Earth Science Division, Bldg 50E } \\
\text { Berkeley, CA } 94720\end{array}$ \\
\hline $\begin{array}{l}\text { Project Manager: } \\
\text { Isamu Aoki }\end{array}$ & $\begin{array}{l}\text { Principal Investigator: } \\
\text { Marcelo } \mathrm{J} \text {. Lippman }\end{array}$ \\
\hline $\begin{array}{r}\text { Telephone: (208) } 526-0583 \text { (Com) } \\
583-0583 \text { (FTS) }\end{array}$ & $\begin{aligned} \text { Telephone: (415) } & 486-5035 \text { (Com) } \\
& 451-5035 \text { (FTS) }\end{aligned}$ \\
\hline Contract Number: ACO3-76SF00098 & Contract Period: 10/17/83-Open \\
\hline Contract Funding: FY $1988 \$ 175,000.00$ & \\
\hline & $\bullet$ \\
\hline
\end{tabular}

Description:

Develop and test downhole-geophysical methods for detecting and mapping fractures in geothermal systems.

\section{Activities/FY88 Milestones:}

Complete the numerical evaluation for detecting and resolving single and multiple fracture zones by means of surface-to-borehole and crosshole electromagnetics in the audio frequency domain.

Accomplishments to Date:

Developed numerical codes to calculate the electromagnetic response due to thin fracture zones of arbitrary orientation and dimensions.

Evaluated geophysical and engineering constraints for crosshole electromagnetic systems.

Applied $P$ - and $S$-wave vertical seismic profiling techniques to map fracture orientations at The Geysers and at the Salton Sea geothermal fields.

\section{Major Reports to Date:}

Daley, T.M., McEvilly, T.V. and Majer, E.L., 1988, "Analys is of S-wave data from the Salton Sea Scientific Drilling Project". Jour. Geophys. Res. (in press). 
Dallal,-S.L., 1985, "Electromagentic scale modeling for the detection of fractures and cavities". Univ. of California at Berkeley, M.S. thesis, Engineering.

Majer, E.L., McEvilly, T.V., Eastwook, F.W., and Myer, L.R., 1988, "Fracture detection using $P$ - and $S$-wave vertical seismic profiling at The Geysers". Geophysics, V. 53, No. 1, pp. 76-84.

Zhou, Q., et al., 1987. "Fracture detection using subsurface electromagnetic techniques, in Farmer. I.W.". et al., eds., Rock Mechanics: Proc. 28th U.S. Symposium, A.A. Balkema, Rotterdam, pp. 5-17. 
Task: Reservoir Technology

Project: Exploration Technology

GTD Manager: Marshall Reed

\begin{tabular}{|c|c|}
\hline Geophysical Methods & to Locate Reservoirs \\
\hline $\begin{array}{l}\text { Directing Organization: } \\
\text { Idaho Operations Office } \\
785 \text { DOE Place } \\
\text { Idaho Falls, ID : } 83402\end{array}$ & $\begin{array}{l}\text { Contractor: } \\
\text { University of Utah Research Institute } \\
391 \text { Chipeta Way, Suite C } \\
\text { Salt Lake City, UT } 84108\end{array}$ \\
\hline $\begin{array}{l}\text { Project Manager: } \\
\text { Isamu Aoki }\end{array}$ & $\begin{array}{l}\text { Principal Investigator: } \\
\text { P. Michael Wright }\end{array}$ \\
\hline $\begin{array}{r}\text { Telephone: (208) } 526-0583 \text { (Com) } \\
583-0583 \text { (FTS) }\end{array}$ & Telephone: (801) $\begin{array}{r}524-3439 \text { (Com) } \\
588-3439 \text { (FTS) }\end{array}$ \\
\hline Contract Number: AC07-85ID12489 & Contract Period: 10/25/84-05/05/90 \\
\hline Contract Funding: FY 88 & . \\
\hline
\end{tabular}

Description:

Objectives include the development of numerical modeling, development of techniques for noise reduction of magnetotelluric data, determination of electrical properties of drill: core from the Cascades, and the integrated study of observed surface geophysical data, physical property results, and geologic data from the Cascade volcanic province.

Activities/FY88 Milestones:

Determine physical properties of Cascades drill core.

Refine 3-D magnetotelluric modeling algorithms.

Upgrade magnetotelluric field recording system.

Interpret Long Valley MT data.

Acquire and interpret aeromagnetic data at Los Azufres

\section{Accomplishments to Date:}

Determined electrical resistivity, magnetic susceptibility, and induced polarization properties for Cascade drill core.

Identified IP response as possible discriminator of geothermal vs low grade alteration in Cascades.

Completed interpretation of Long Valley MT data. 
Completed development and deployment of UURI MT field system.

Completed new MT modeling techniques.

Completed fixed wing and helicopter aeromagnetic surveys at Los Azufres. Major Reports to Date:

Ross, H. P., and Moore, J. N., 1985, "Geophysical investigations of the Cove Fort-Sulphurdale geothermal system, Utah", Geophysics, v. 50, p. $1732-1745$.

Tripp, A. C., Lemieux, M. M., Wright, p. M., and Moore, J. N., 1988, "Induced polarization response of related Cascade core samples". GRC Trans., v. 12, (in press).

Wannamaker, P. e., 1983, "Resistivity sturcture of the Northern Basin and Range," in GRC Spec. Rept. 13, "The role of heat in the development of energy and mineral resources in the northern Basin and Range Province," p. 345-362.

Wannamaker, P. E., Stodt, J. A., and Rijo, L., 1985, "PW2D Finite element program for solution of magnetotelluric responses of Two-dimensional earth resistivity structure:" User Documentation: DOE/SAN/12196-13, ESL Rept. No. $158,40 \mathrm{p}$.

Wannamaker, P. E., 1988, "Magnetotelluric profile across Long Valley caldera", in Proc. of the symposium on the Long Valley caldera: a pre-drilling data review, ed. by N. L. Goldstein, LBL Rept. 23940, p. 150-158.

Ward, S. H., 1983, "Geophysical studies of active geothermal systems in the northern Basin and Range," in GRC Spec. Rept. No. 13, "The role of heat in the development of energy and mineral resources in the northern Basin and Range Province," p. 121-158.

Wright, P. M., 1985, "Application of geophysics for concealed hydrothermal systems in volcanic terrains". GRC Trans., v. 9, p. 423-429.

Wright, P. M., Ward, S. H., Ross, H. P., and West, R., 1985, "State-of-the-art geophysical exploration for geothermal resources". Geophysics, v. 50, p. 2666-2699.

Wright, P. M., and Nielson, D. L., 1986, "Electrical resistivity anomalies at Newberry volcano, Oregon: Comparison with alteration mineralogy in GEO Corehole N-1," GRC Trans., v.10, p. 247-252. 
Task: Reservoir Technology

GTD Manager: Marshall Reed

Project: Exploration Technology

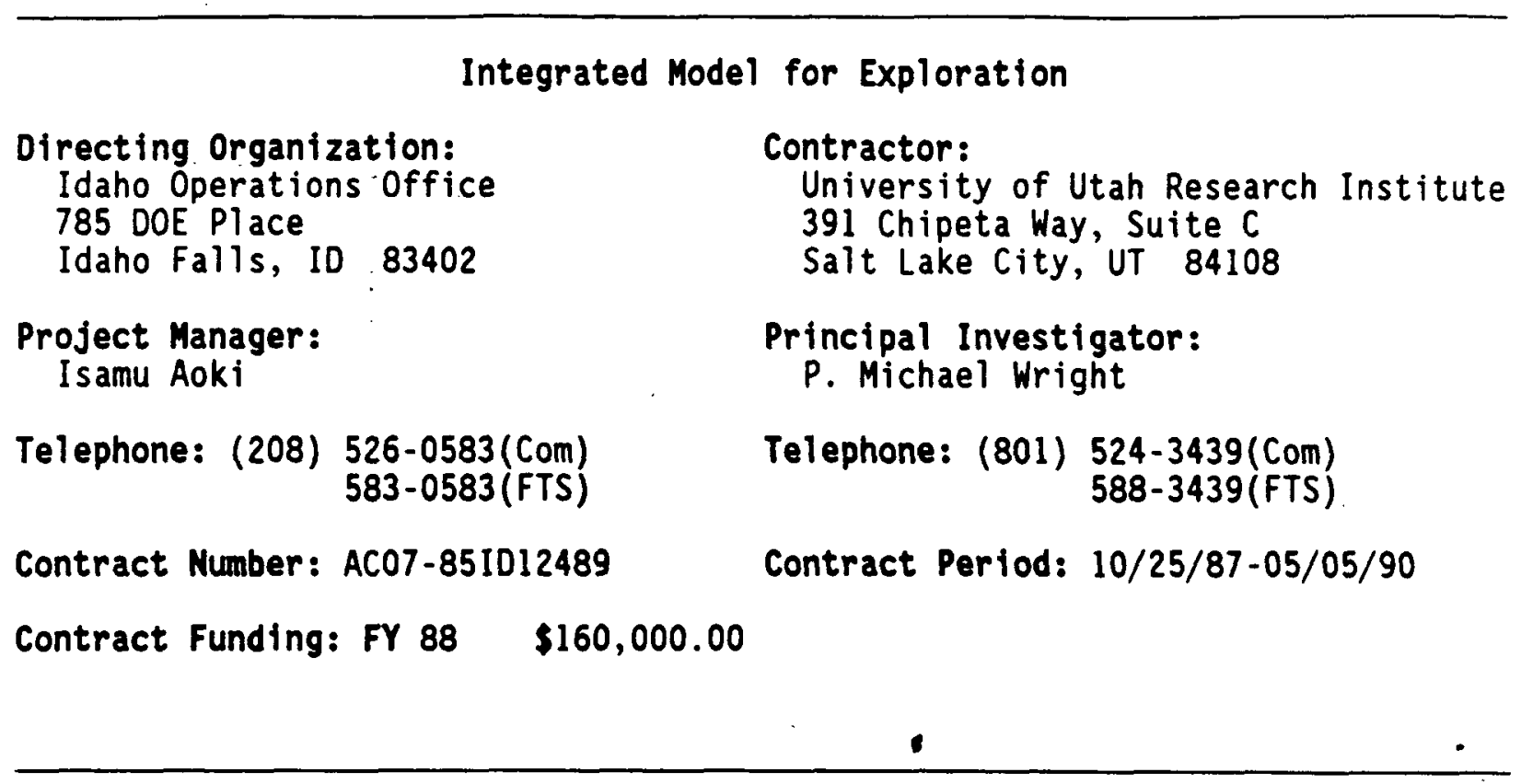

Description:

Synthesis of geothermal knowledge to target the environment of hydrothermal systems.

\section{Activities/FY88 Milestones:}

Application of hydrogeochemical models developed through cooperative DOE-Industry programs to exploration.

Use results of rock property studies to define characteristics of geothermal targets in volcanic terrains. development.

Organize and edit a case-studies textbook on geothermal exploration and

Conduct workshops on geothermal exploration for third world countries

Conduct geothermal exploration in St. Lucia and Mexico.

\section{Accomplishments to Date:}

Successfully sited discovery well in St. Lucia based on integrated model approach.

Prepared case studies of Roosevelt Hot Springs, San Emidio, Cove Fort.

Analyzed several possible uses of exploration methods and strategies. 


\section{Major Reports to Date:}

Sorey, M., Reed, M., Foley, D., and Renner, J., 1983, "Low-temperature geothermal resources in the central and eastern United States". USGS, Circular 892, p. 51-66. ESL-83005-TR.

Struhsacker, E., Smith, C., and Capuano, R. M., 1983, "An evaluation of exploration methods for low-temperature geothermal systems in the Artesian City Area, Idaho". Geological Society of American Bulletin, v. 94, p. 58-79.

Ward, S. H, 1983, "Geophysical Studies of active geothermal systems in the Basin and Range". Geothermal Resources Council Special Report No. 13, p. $121-157$.

Wright, P. M., Ward, S. H., Ross, H. P., and West, R., 1985, "State-of-the-art geophysical exploration for geothermal resources". Geophysics, v. 50, p. 2666-2699. 
Task: Reservoir Technology

Project: Exploration Technology

GTO Manager: Marshall J. Reed

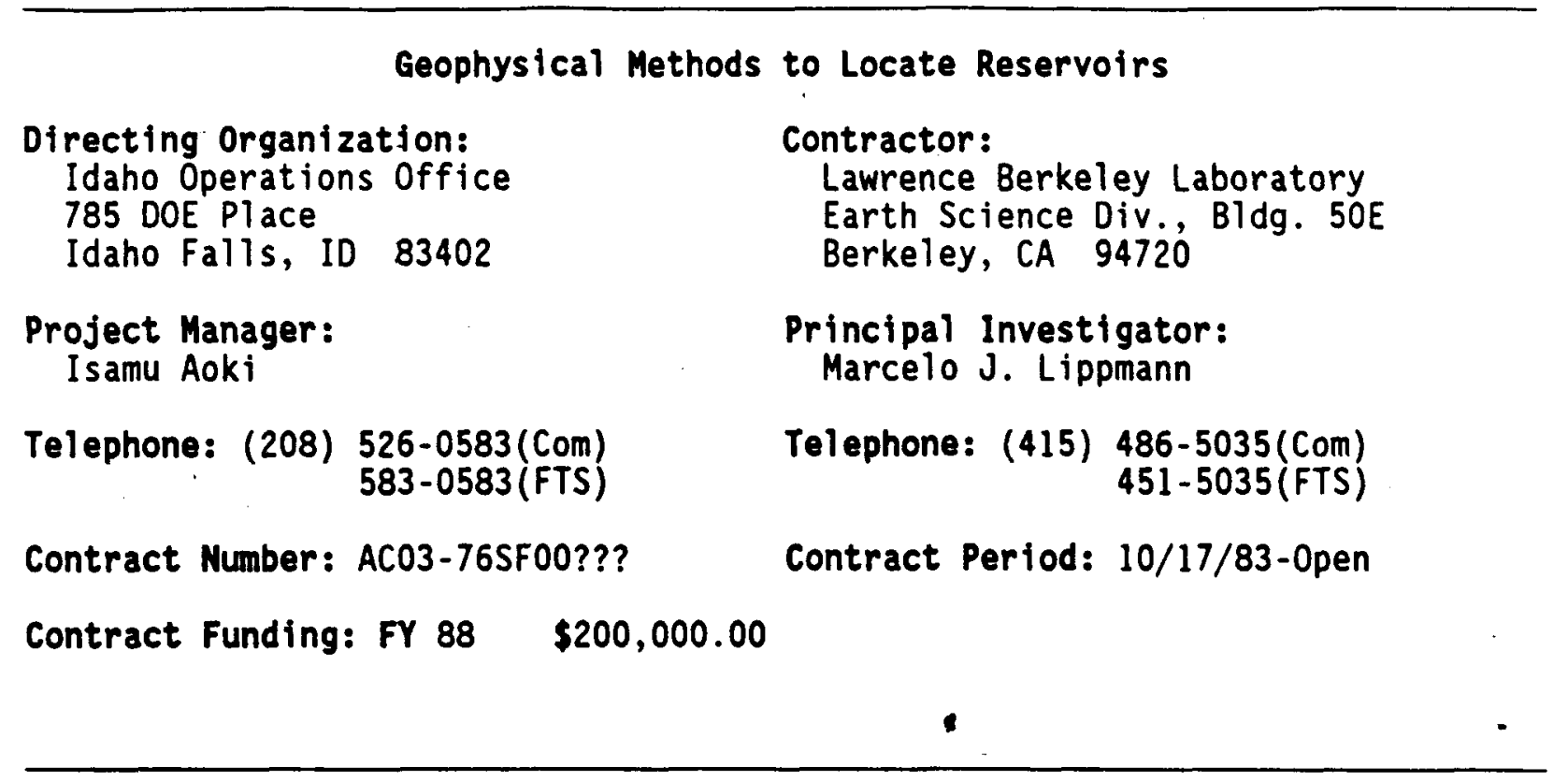

Description:

Develop, test, and demonstrate surface geophysical techniques and interpretation methods for locating fractured hydrothermal systems.

Activities/FY88 Milestones:

Complete analysis on 3-dimensional interpretation of gravity data Accomplishments to Date: sources

Demonstrated the use of surface strain analysis to locate midcrustal heat

Conducted a major symposium on the Long Valley caldera

Demonstrated the use of active seismic and gravity to delineate faults and alteration related to geothermal fields.

Demonstrated the use of passive seismic (natural earthquakes) to map the two-phase zones at The Geysers

Demonstrated the use of controlled-source electromagnetics and magnetotellurics to locate reservoir rocks in the Basin and Range

Major Reports to Date:

Blakeslee, S., 1984, "Seismic discrimination of a geothermal field: Cerro Prieto," Trans. Geotherm. Resour. Counci1, V. 8, pp. 183-188. 
Carle, S.F. and Goldstein, N.E., 1987, "Gravity and fault structures, Long Valley caldera, California," Trans. Geoth. Res. Council, V. 11, pp. 327-332.

Goldstein, N.E., ed., 1987, "Proceedings of the Symposium on the Long Valley caldera," Lawrence Berkeley Laboratory report LBL-23940, $195 \mathrm{p}$

Goldstein, N.E: and Carle S., 1986, "Faults and gravity anomalies over the East Mesa hydrothermal-geothermal system," Trans. Geoth. Res. Council, V.10, pp. 223-228.

O'Connell, D.R., 1986, "Seismic velocity structure and microearthquake source properties at The Geysers, California, geothermal area," Lawrence Berkeley Laboratory report LBL-22280.

Severson, L., 1987, "Interpretation of shallow crustal structure of the Imperial Valiey, California, from seismic reflection profiles, " Lawrence Berkeley Laboratory report LBL-23888.

Vasco, D.W, Johnson, L.R., and Goldstein, N.E., 1988, "Using surface displacement and strain to constrain deformation at depth, with an application to Long Valley caldera, CA", Jour. Geophys. Res., V. 93, pp. 3232-3242.

Wilt, M.J. et al., 1983, "Experience with the EM-60 electromagnetic system for geothermal exploration in Nevada," Geophysics, V. 48, pp. 1090-1101. 
Task: Reservoir Technology

Project: Brine Injection Technology

GTD Manager: Marshall Reed

\section{Tracer Development and Interpretation}

Directing Organization:

Idaho Operations office

785 DOE Place

Idaho Falls, ID 83402

Project Manager:

I samu Aoki

Telephone: (208) 526-0583(Com)

$583-0583$ (FTS)

Contract Number: AC07-76ID01570

Contract Funding: FY $88 \quad \$ 100,000.00$
Contractor:

Idaho National Engineering Laboratory P.0. BOX 1625

Idaho Falls, ID 83415

Principal Investigator: Joel Renner

Telephone: (208) 526-9824(Com) $583-9824$ (FTS)

Contract Period: 01/01/82-Open

Description:

The objective of this project is to develop geothermal tracers and techniques for tracer injection, sampling and interpretation as applied to the determination of reservoir physical properties and fluid interactions in the reservoir.

\section{Activities/FY88 Milestones:}

Predict the range of tracer dispersion in tests at the Dixie Valley reservoir as a basis for design of tracer injection.

\section{Accompl ishments to Date:}

Models have been used to estimate the dispersion of tracer in the Dixie Valley reservoir based on various production-injection well combinations and reservoir assumptions.

Studies related tracer returns in injection-backflow tests East Mesa and Raft River to injection volume, formation characteristics and background reservoir flow patterns.

\section{Major Reports to Date:}

Russe1, B.F., Hull,L.C., and Downs, W.F., "Response of East Mesa and Raft River Reservoirs to Injection-Backflow Testing". Proceedings: Ninth Geothermal Reservoir Engineering Workshop, Stanford University, SGP-TR-74, Stanford, CA, 1983. 
. 
Task: Reservoir Technology

Project: Brine Injection Technology

GTD Manager: Marshall Reed

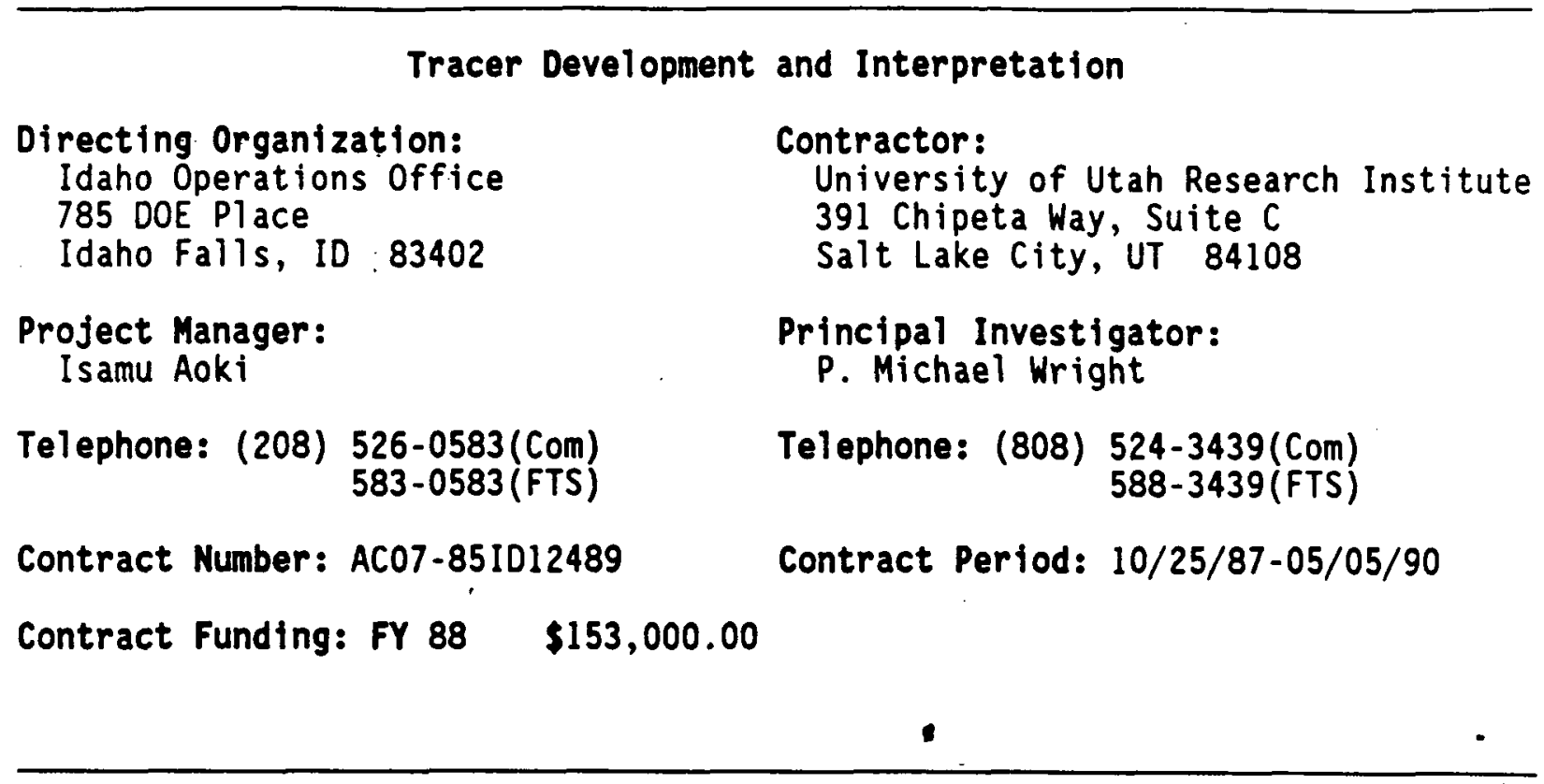

Description:

Development of tracers and interpretation methods to track transport of injected fluid.

Activities/FY88 Milestones:

Determine temperature dependence of fluorescein decay. tracers.

Develop enrichment techniques for lowering detection 1 imits of hydrocarbon

Conduct laboratory experiments to define levels of preservatives needed to prevent biodegradation of tracers in sample bottles.

Prepare reports on analytical method development for tracers, tracer stabilities, and fluorescein kinetics.

Conduct field test of newly-developed tracers at the Pleasant Bayou geopressured well and the Dixie Valley geothermal field.

Accomplishments to Date:

Tested 39 hydrocarbon compounds as potential geothermal tracers. Compounds were tested to evaluate the effects of temperature, time, fluid composition, presence of oxygen, $\mathrm{pH}$, and rock adsorption and catalysis.

Identified 15 compounds as stable under high-temperature conditions. 
Tested all of the non-radioactive conventional tracers in an injection-backflow test at the East Mesa geothermal field.

Successfully used tracers to track the progress and efficiency of a scale-inhibitor injected into the geopressured Pleasant Bayou Well using fluorescein and benzenesulfonic acid.

\section{Major Reports to Date:}

Adams, M.C., 1985, "Tracer stability and Chemical Changes in an Injected Geothermal Fluid during East Mesa Injection Testing". Proceedings, 10th Workshop on Geothermal Reservoir Engineering, Stanford University, P. 247-252.

Adams, M.C., Ahn, J.H., Bentley, H., Moore, J.N., and Veggeberg, S., 1986, "Devrivitized Hydrocarbons as Geothermal Tracers". Geothermal Resources Council Transactions, v. 10, p. 415-420.

Adams, M.C., Ahn, J.H., Bentley, H., Moore, J.N., and Beggeberg, S., 1986, "Tracer Developments: Results of Experimental Studies". 11th Workshop on Geothermal Reservoir Engineering, Stanford University p. 97-102.

Capuano, R.M., Adams, M.C., and Wright, P.M., 1983, "Tracer Recovery and Mixing from two Geothermal Injection-Backfiow Studies". Proceedings, 9th Workshop on Geothermal Reservoir Engineering, Stanford University, p. 299-304.

Wright, P.M., Capuano, R.M., Adams, M.C., and Moore, J.N., 1984, "Uses of Geochemistry with Injection-Backflow Testing in Geothermal Reservoir Studies". Geothermal Resources Council Transactions, v. 8, p. 349-354. 
Task: Reservoir Technology

Project: Brine Injection Technology

GTD Manager: Marshall Reed

\begin{abstract}
Geophysical Methods for Injection Monitoring
Directing Organization:

Idaho Operations Office

785 DOE Place

Idaho Falls, ID : 83402

Contractor:

University of Utah Research Institute 391 Chipeta Way, Suite C

Project Manager:

I samu Aoki

Principal Investigator:

Salt Lake City, UT 84108

Telephone: (208) 526-0583(Com)

583-0583 (FTS)

Telephone: (801) 524-3439(Com)

588-3439(FTS)

Contract Number: AC07-85ID12489

Contract Period: 10/25/87-05/05/90

Contract Funding: FY $88 \quad \$ 30,000.00$

Description:

The objective of this project is to examine the feasibility of using surface geophysical methods to monitor the flow of injected fluids. The two methods most appropriate to this study appear to be the self-potential and electrical resistivity methods.

Activities/FY88 Milestones:

Conduct SP field experiment during injection.

$\mathrm{Pl}$ anned experiment to measure the SP effect in detail at frequent intervals at a large number of field sites.

Accomplishments to Date:

Extended basic theory for self-potential fields resulting from cross-coupled fluid flow, establishing the state-of-the-art.

An advanced cross-coupled fluid flow model was developed for the modiling and interpretation of self-potential data.

Existing algorithms were used to predict electrical resistivity results.

Completed field self-potential and electrical resistivity surveys during injection studies at Raft River and East Mesa. Demonstrated that only very low-amplitude anomalies occur.
\end{abstract}


Major Reports to Da: ?:

Still, W. R., 1:33, "Interpretation of SP measurements during injection tests at Raft River, Idaho". DOE/ID/12079-103, ESL Rept. No. 120, 20 p.

Sil1, W.R., 1983, "Resistivity measurements before and after injection test No.'5 at Raft River KGRA, Idaho". DOE/ID/12079104, ESL Rept. No. 121, 14 p.

Sill, W.R., 1983, "Self-potential modeling from primary flows". Geophysics, v.48, p. 76-86. 
Task: Reservoir Technology

Project: Brine Injection Technology

\footnotetext{
Modeling Injected Fluid Migration

Directing Organization:

Idaho Operations office

785 DOE Place

Idaho Falls, ID : 83402

Project Manager:

Is samu Aoki

Telephone: (208) 526-0583(Com)

$583-0583$ (FTS)

Contract Number: AS07-84ID12529

Contract Funding: FY $88 \quad \$ 125,000.00$

Contractor:

Department of Petroleum Engineering Stanford Univ., 360 Mitchell Bld

Stanford, CA 94305

Principal Investigator:

Rol and Horne

Telephone: (415) 723-9595(Com)

Contract Period: 07/25/84-05/05/89

Description:

Development of modeling capability to predict flow of injected fluid through reservoirs.

Activities/FY88 Milestones:

Experimental program to identify transport mechanisms governing flow of tracers through fractures.

Accomplishments to Date:

Completed experimental studies of tracer adsorption and dispersion.

Constructed a physical model to represent flow through fractured rock.

Major Reports to Date:

Al-Riyami, Yathrib M., 1986, "Thermal Stability of Fluorescent Dyes as Geothermal Tracers". December 1986. SGP-TR-106

Bouett, Lawrence W., 1986, "The Effect of Transverse Mixing on Tracer Dispersion in a Fracture". June 1986. SGP-TR-103

Chrysikopoulos, Constantinos Vassiliou, and Kruger, Paul, 1986, "Chelated Indium Activable Tracers for Geothermal Reservoirs." June 1986. SGP-TR-99

Gilardi, John R., 1984, "Experimental Determination of the Effective Taylor Dispersivity in a Fracture". June 1984. SGP-54-78
} 
Johns, Robert Anthony, 1987, "Injection Through Fractures". May 1987. SGP-TR-110

Pulskamp, J. Flint, 1985, "The Generation of Response Curves from Laboratory Tracer Flow Experiments". December 1985. SGP-TR-94

Walkup, Gardner William, Jr., 1984, "Characterization of Retention Processes and Their Effect on the Analysis of Tracer Tests in Fractured Reservoirs". June 1984. SGP-TR-77 
Task: Reservoir Technology

Project: Brine Injection Technology

GTD Manager: Marshall Reed

\section{Modeling Injected Fluid Migration}

Directing Organization:

Idaho Operations office

785 DOE Place

Idaho Falls, ID : 83402

Project Manager:

I samu Aoki

Telephone: (208) 526-0583(Com)

$583-0583$ (FTS)

Contract Number: AC03-76SF00098

Contract Funding: FY $88 \quad \$ 250,000.00$
Contractor:

Lawrence Berkeley Laboratory

Earth Science Div., Bldg. 50E

Berkeley, CA 94720

Principal Investigator:

Marcelo J. Lippmann

Telephone: (415) 486-5035(Com)

$451-5035$ (FTS)

Contract Period: 10/17/83-0pen

Description:

Develop and demonstrate modeling techniques for predicting and monitoring the movement of injected geothermal fluids in the subsurface

Activities/FY88 Milestones:

Evaluate the applicability of different well testing and analys is methods to actual field pressure transient injection test data

Investigate and develop numerical techniques that permit realistic modeling of the heat sweep associated with injection into fractured reservoirs

Develop solutions for heat transfer at a boiling front moving through a porous media reservoir

Analyze injection data from the Los Azufres geothermal field Accomplishments to Date:

Developed techniques to model sharp (thermal, phase and compositional) fronts associated with injection of brines into geothermal reservoirs

Designed well testing procedures and data analysis methods for non-isothermal conditions associated with injection tests

Obtained analytical solutions for complex non-isothermal flow problems associated with injection into hydrothermal systems 


\section{Major Reports to Date:}

Benson, S. M., 1984, "Analys is of Injection Tests in Liquid-Dominated Geothermal Reservoirs," M. S. Thesis, LBL-17953.

Benson, S. M., and Lai, C. H., 1985, "A New Method for Evaluating Composite Reservoir Systems," Geothermal Resources Council Trans., Vol. 9, II, pp. 487-492, LBL-19193.

Bodvarsson, G. S., and Lai, C. H., 1982, "Studies of Injection into Naturally Fractured Reservoirs," Geothermal Resources Council Trans., Vol. 6, pp. 245-248, LBL-14519.

Badvarsson, G. S., Pruess, K., and O'Sullivan, M. J., 1985, "Injection and Energy Recovery in Fractured Geothermal Reservoirs," Soc. Pet. Engr. Jour., Vo1. 25, No. 2, pp. 303-312, LBL-15344.

Bodvarsson, G. S., and Stefansson, V., 1987, "Reinjection into Geothermal Reservoirs", to be published in the Proceedings of the NATO Course in Advanced Geothermal Reservoir Engineering, Antalya, Turkey, July 1-10, 1987.

Calore, C., Pruess, K., and Celati, R., 1986, "Modeling Studies of Cold" Water Injection into Fluid-Depleted Vapor-Dominated Geothermal Reservoir," Proc. Eleventh Workshop Geothermal Reservoir Engineering, Stanford, CA, report SGP-TR-93, Pp. 161-168, LBL-21252.

Pruess, K., and Bodvarsson, G. S., 1984, "Thermal Effects of Reinjection in Geothermal Reservoir with Major Vertical Fractures," Jour. Petr. Tech., Vol. 36, No. 10, pp. 1567-1578, LBL-16269.

Pruess, K., and Wu, Y. S., 1988, "A Semi-Analytical Method for Heat Sweep Calculations in Fractured Reservoirs." Presented at 13th Workshop on Geothermal Reservoir Engineering. 
Task: Reservoir Technology

Project: Brine Injection Technology

GTD Manager: Marshall J. Reed

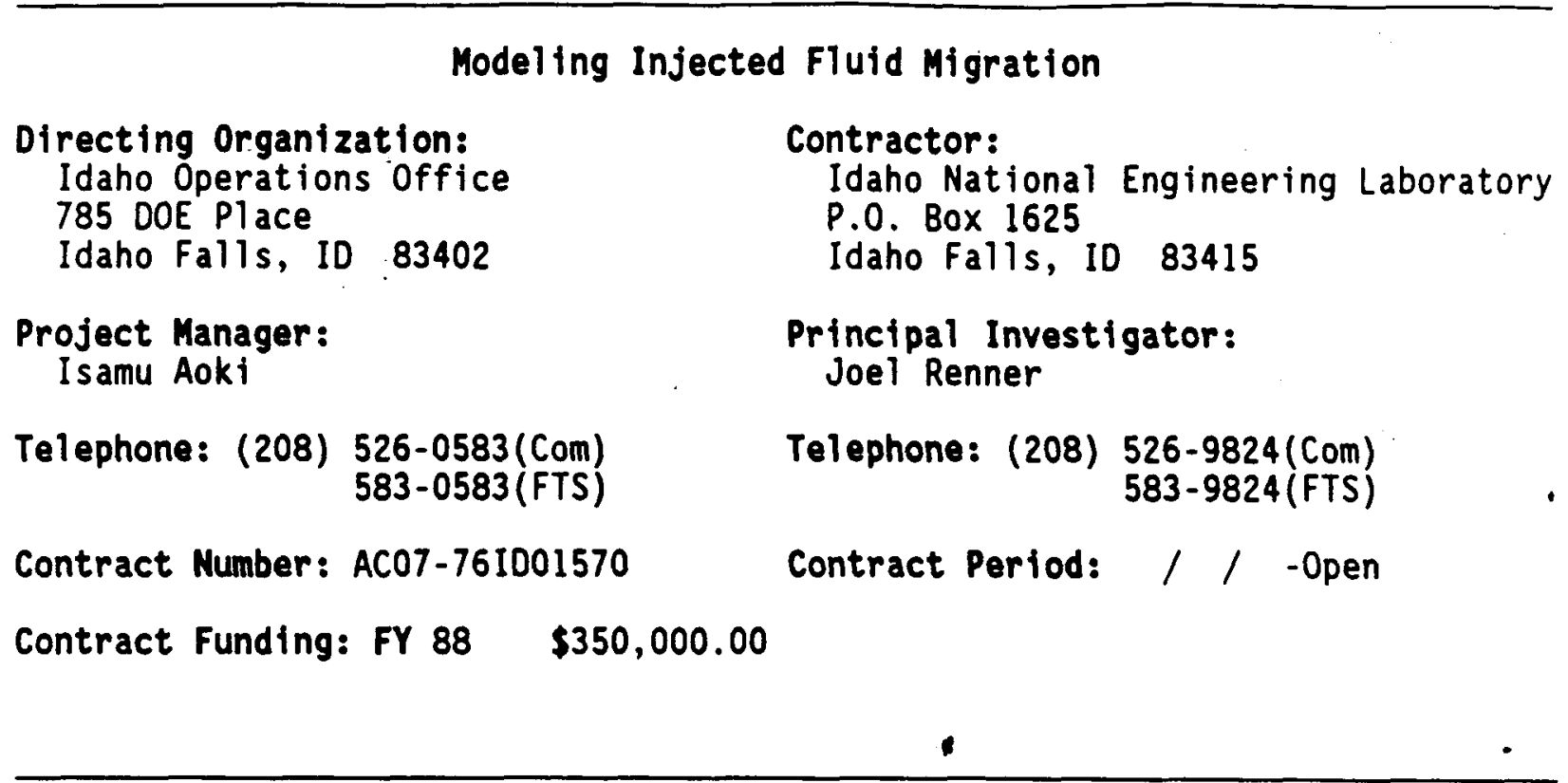

Description:

The objective of this project is to develop computer modeling capability to predict flow, transport and thermal breakthrough of injected fluids in a fractured or complex geothermal reservoir.

Activities/FY88 Milestones:

Confirm FRACSL code capabilities with comparison to analytical and other numerical solutions.

Complete code conversion to a self-contained version which is operable on a microprocessor or a workstation.

Prepare code enhancements and documentation for transfer to industry, though a training session to be hold in early FY-1989.

\section{Accompl ishments to Date:}

Analyses showed that injection-backflow tracer tests at East Mesa and Raft River prvided positive information on formation characteristics and mixing.

Physical models were successfully used to develop an understanding of fundamental processes occurring in single fractures and fracture networks, and demonstrated that common assumptions regarding tracer flow were in error.

The FRACSL code was successfully validated against data from laboratory models of fracture systems and from analytical studies. 
Studies showed that the dual permeability approach can be used to represent the complete range of fractures in a reservoir-scale model.

The FRACSL code was used to demonstrate differences in predicted breakthrough curves for hydraulically equivalent reservoir representations.

The dual permeability approach was extended to three-dimensions. Major Reports to Date:

Clemo, T.M., 1986, "Representative Element Modeling of Fracture Systems Based on Stochastic Analysis", Proceedings: eleventh workshop on Geothermal Reservoir Engineering, Stanford University, SGP-TR-93, PD. 71-76.

Downs, W.F., R.E. McAtee, R. M. Capuana, and W. Sill, 1982, "Hydrothermal Injection Experiments at the Raft River KGRA, Idaho", Proceedings: Eighth Workshop on Geothermal Reservoir Engineering, Stanford University, SGP-TR-60, pp. 275-278.

Hull, L.C., 1982, "Changes in Fluid Chemistry During Injection, Raft River KGRA," Geothermal Resources Council Bulletin, 114, pp. 11-14.

Hul1, L.C., and K.N. Koslow, 1984, "Physical Model Studies of Dispersion in Fracture Networks", (Invited Paper), Penrose Conference on Transport in Fractured Rocks, Geological Society of America, Park City, UT.

Hull, L.C., and 1985, "Laboratory Validation of a Dual-Permeability Reservoir Code", Proceedings, Tenth Workshop on Geothermal Reservoir Engineering, Stanford University, SGP-TR-84, Pp. 293-296.

Hull, L.C., and K.N. Koslow, 1986, "Streamline Routing Through Fracture Junctions," Water Resources Research, 22(12), pp. 1731-1734.

Hull, L.C., J.D. Millier and T.M. Clemo, 1987, "Laboratory and Simulation Studies of Solute Transport in Fracture Networks, "Water Resources Research, 23(8), pp. 1505-1513.

Hull, L.C., T.M. Clemo, 1988, "Sensitivity Analysis of Dual-Permeability Systems", Proceedings: Twelfth Workshop on Geothermal Reservoir Engineering, Stanford University, in press.

Miller, J.D., 1983, "A Fundamental Approach to the Simulation of Flow and Dispersion in Fractured Media", Proceedings: Ninth Workshop on Geotherma 1 Reservoir Engineering, Stanford University, SGP-TR-74, PD. 373-380.

Miller, J.D., and D.W. Allman, 1986, "Dual-Permeability Modeling of Flow in a Fractured Geothermal Reservoir", Proceedings: Eleventh Workshop on Geothermal Reservoir Engineering, Stanford University, SGP-TR-93, PD. 77-84.

Stiger, S.G. and J.L. Renner, 1987, "Reservoir Technology Research at the Idaho National Engineering Laboratory," Geothermal Resources Council Transactions, Vol. 11, pp. 565-569. 
Tạsk: Reservoir Technology

Project: Brine Injection Technology

Tracer Development and Interpretation

Directing Organization: Idaho Operations Office 785 DOE PIace

Idaho Falls, ID : 83402

Project Manager:

Isamu Aoki

Telephone: (208) 526-0583(Com) $583-0583$ (FTS)

Contract Number: AS07-841012529

Contract Funding: FY $88 \quad \$ 115,000.00$
Contractor:

Department of Petroleum Engineering Stanford Univ., 360 Mitchell Bldg

Stanford, CA 94305

Principal Investigator:

Roland Horne

Telephone: (415) 723-9595(Com)

Contract Period: 07/25/84-05/05/89

Description:

Development of tracers and interpretation methods to track transport of injected fluid.

Activities/FY88 Milestones:

Development of reservoir flow models to be used for the interpretation of tracer tests.

Accomplishments to Date:

Completed models for the interpretation of tests in fractured reservoirs.

Developed technique to use tracer test results to design optional reinjection scheme.

Continued results of methodology in several field experiments.

Major Reports to Date:

Cindrich, R.B., 1984, "Application of Stable Isotope and Geochemical Techniques to Problems in Tracing Geothermal Recharge, The Reykjanes Peninsula." June 1984. SGP-TR-79.

Jensen, C.L.,1983, "Matrix Diffusion and Its Effect on the Modeling of Tracer Returns from the Fractured Geothermal Reservoir At Wairakei, New Zeal and". December 1983. SGP-TR-71. 
Johnson; S.E., 1984, "Tracer Test Analys is of the Klamath Falls Geothermal Resource: A Comparison of Models". June 1984, SGP-TR-81.

Kocabas, I., 1986, "Analysis of Injection-Backflow Tracer Tests" April 1986. SGP-TR-96.

Lovekin, J., 1987, "Optimization of Injection Scheduling in Geothermal Fields". May 1987. SGP-TR-114. 
Task: Reservoir Technology

Project: Geothermal Technology Organization

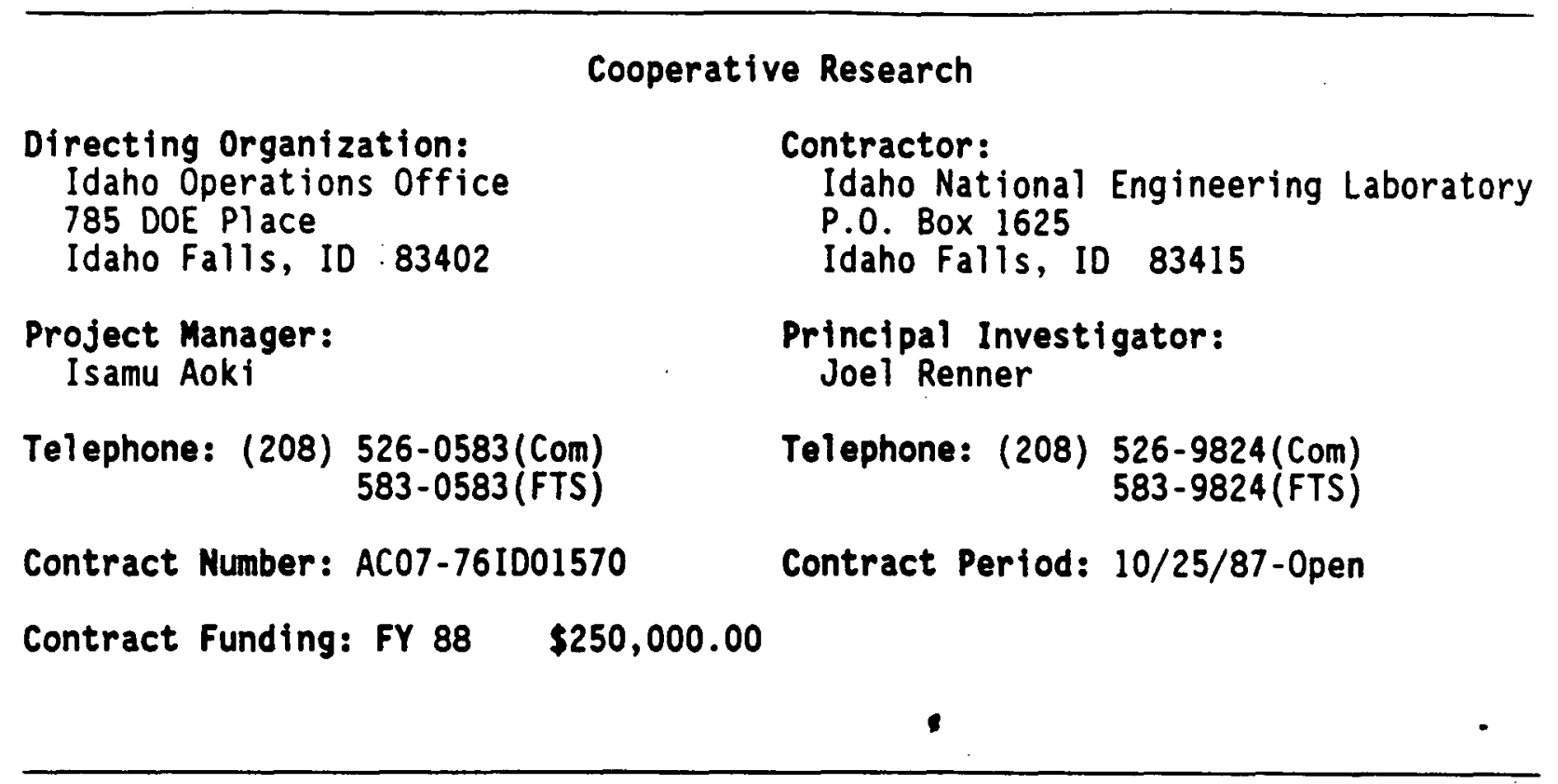

Description:

The objective of this project is to sponsor cooperative technological development with the geothermal industry through a cooperative research agreement between the DOE/Idaho Operations Office and the Geothermal Technology Organization (an industry group formed pursuant to the National Cooperative Research Act of 1984). The research selected for funding should have a high likelihood of yielding near-term benefits. INEL works with the industry group to select research projects and is responsible for conducting the selected research through contracts.

\section{Activities/FY88 Milestones:}

Deploy and record data from an advanced seismic array at The Geysers geothermal field.

Develop sophisticated seismic techniques for monitoring the effects of injection on a geothermal field.

Accomplishments to Date:

Seismic systems have been deployed and data collection has begun. Major Reports to Date:

None to date. 


\subsection{Hard Rock Penetration Research}

Status

Description
The captial costs for drilling production and injection wells are still a significant fraction (35 to 50\%) of the costs of a typical, commercial geothermal project. This is due primarily to the heat, hard rock, and harsh fluid chemistry encountered during geothermal drilling.

Innovative drilling and well completion methods include wellbore fracture mapping tools, techniques from mapping interior features of boreholes, improved materials for lost circulation control and instruments to measure, record, and transmit critical downhole drilling parameters. The feasibilities of various advanced drilling concepts are being evaluated, and, in cooperation with industry, the components of a prototype system are being defined.

A major effort is directed at developing lost circulation control, materials and practices. Lost circulation in the drilling fluid is, by industry consensus, the single most expensive consideration in geothermal drilling because of the time and expense incurred in recovering circulation. The R\&D effort includes developing, through analyses and experiments, a basic understanding of the two-phase flow phenomena that control fracture plugging, evaluating the high-temperature plugging characteristics of specific lost circulation materials, and developing special downhole systems for sealing wellbores.

Rock penetration mechanics includes the development of insulated drill pipe for hightemperature deep drilling, and development of advanced technology for the hot, deep, hard rock conditions encountered by geothermal wells.

Instrumentation deals with research in the development of tools which will improve fracture mapping techniques, downhole pressure and flow rate measurements, and other procedures in the high temperature and corrosive fluid environment found downhole in geothermal wells.

Industry cost-shared research through the Geothermal Drilling Organization includes several projects which are being developed to the point 
where joint industry and government support can be sought for final development and technology transfer. The most recent development projects in this area are drill string dynamics computer codes, a radar fracture mapping tool, borehole diagnostics, and geothermal stimulation.

An example of the innovations involved in these technologies is the use of directional antennas for both the transmitter and the receiver in a single fracture mapping tool that provides both the distance and the direction of a fracture in a downhole application. Unique downhole sampling and uphole data processing techniques are used to obtain high-frequency data using standard logging cable. In a recent test conducted in a lake, radar returns from a target were clearly observed. 
Task: Hard Rock Penetration

Project: Lost Circulation Control

GTD Manager: Lew W. Pratsch

\section{Lost Circulation Testing}

Directing Organization:

Albuquerque Operations office

P.0. Box 5400

Albuquerque, NM 87115

Project Manager:

George P. Tennyson

Telephone: (505) 846-3219(Com)

Contract Number: 0728.000

Contract Funding: FY $88 \quad \$ 200,000.00$
Contractor:

Sandia National Laboratories

P.0. Box 5800

Albuquerque, NM 87185

Principal Investigator:

James C. Dunn

Telephone: (505) 844-4715(Com)

Contract Period: 10/17/83-OPEN

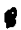

Description:

The objective of the Lost Circulation Testing project is to evaluate plugging characteristics of high-temperature lost circulation materials under a range of temperature and pressure conditions.

Activities/FY88 Milestones:

Complete testing of lost circulation particulates in the Lost Circulation Test Facility at Sandia.

Document design changes of API slot tester and publish conclusions on particulate testing.

Collect data during drilling in the Geysers for characterization of lost circulation zones.

Accomplishments to Date:

Major Reports to Date:

Hinkebein, T. E., Behr, V. L., and Wilde, S. W., "Static Slot Testing of Conventional Lost Circulation Materials". (SAND82-1080), Sandia National Laboratories, 1982.

Loeppke, G. E., and Caskey, B. C., "A Full-Scale Facility For Evaluating Lost Circulation Materials And Techniques". Sandia National Laboratories, Transactions of the Geothermal Resources Counci1, Vol. 7, October 1983. 
Givler, R. C., "Plugging Mechanisms In A Lost Circulation Model". Sandia National Laboratories, Transactions Of 1985 Annual Meeting of Geothermal

Resources Council, Vol. 9-Part I, August 1985. 
Task: Hard Rock Penetration

Project: Lost Circulation Control

GTD Manager: Lew W. Pratsch

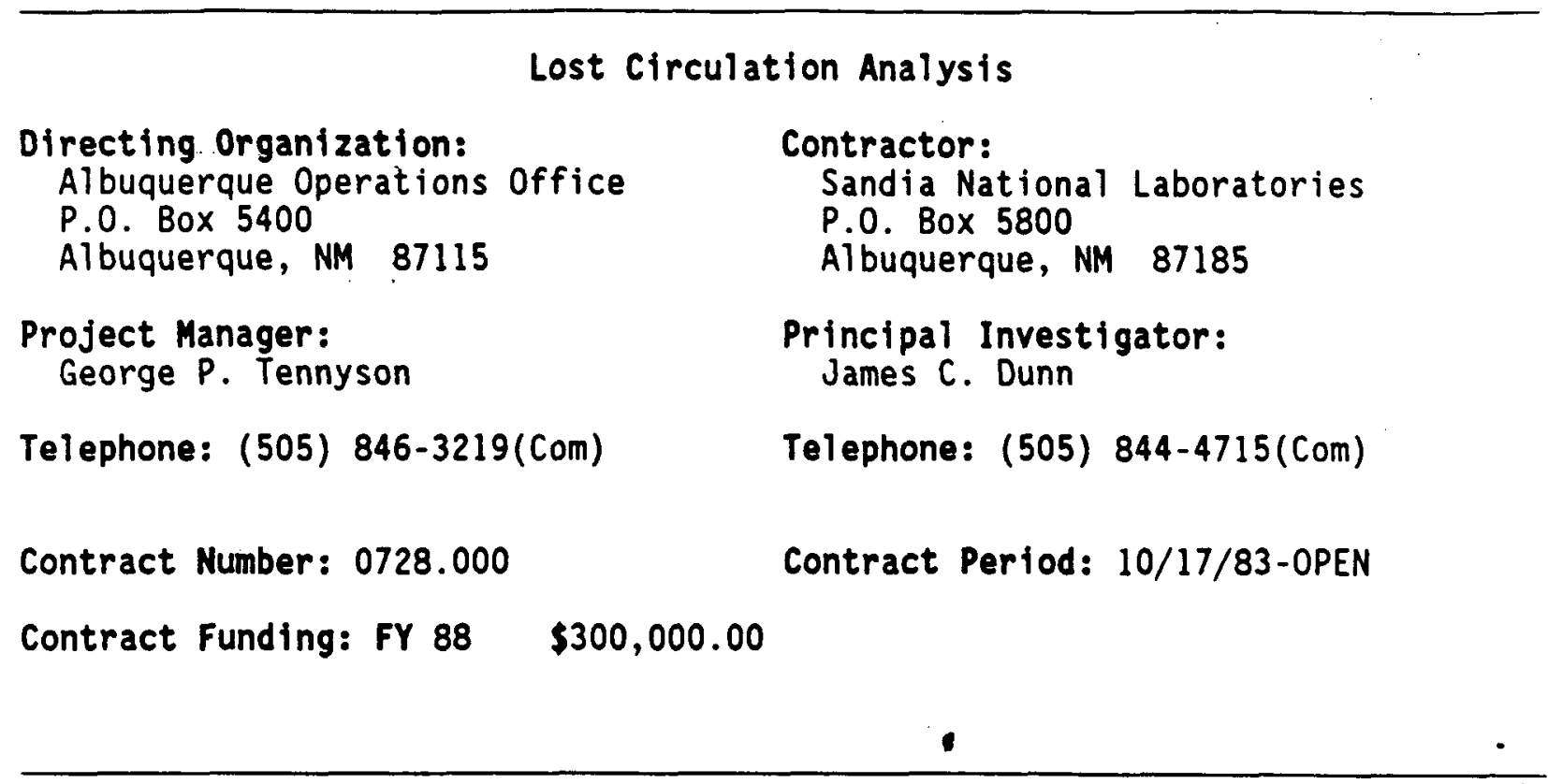

Description:

The objective of the Lost Circulation Analysis Project is to develop a basic understanding of the two-phase (solid/liquid) flow phenomenon that dictates fracture plugging mechanics for single particle, high temperature, and multiple constitutent lost circulation materials.

Activities/FY88 Milestones:

Design and build two-phase decelerating flow experiment.

Develop numerical model of decelerating flow experiment.

Develop analysis of wellbore transient hydraulics during loss of circulation.

Accomplishments to Date:

\section{Major Reports to Date:}

Caskey, B. C., and Loeppke, G. E., "Lost Circulation In Geothermal Wells: Research And Development Status". Sandia National Laboratories, Transactions of The Geothermal Resources Council, Vol. 7, October 1983.

Caskey, B. C., Lost Circulation Technology Workshop, October 9-10, 1984, (SAND-85-0109), Sandia National Laboratories, March 1985. 


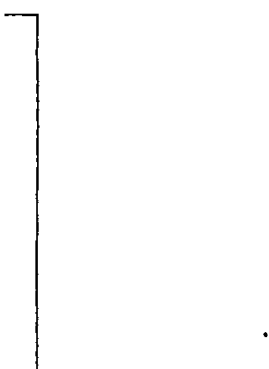

4

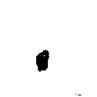

$\cdot$

$\cdot$ 
Task: Hard Rock Penetration Project: Rock Penetration Mechanics

GTD Manager: Lew W. Pratsch

\section{High Temperature Drilling}

Directing Organization:

Albuquerque Operations office P.0. Box 5400

Albuquerque, NM 87115

Project Manager:

George P. Tennyson

Telephone: (505) 846-3219(Com)

Contract Number: 0728.000

Contract Funding: FY $88 \quad \$ 210,000.00$
Contractor:

Sandia National Laboratories

P.0. Box 5800

Albuquerque, NM 87185

Principal Investigator:

James C. Dunn

Telephone: (505) 844-4715(Com)

Contract Period: 10/17/83-OPEN

Description:

To carry out a scientific investigation that will determine if the use of insulated drill pipe will keep fluids cool enough to 1 imit problems in drill strings and hole stability.

Activities/FY88 Milestones:

Complete definition of test $\mathrm{plan}$ and procurement of prototype pipe.

Complete preliminary tests of thermal performance.

\section{Accomplishments to Date:}

Modeling of the formation temperatures and drilling fluid temperatures for general and specific magma-penetrating wells; used model to assess the effect of insulated drillpipe.

Issued contracts to two manufacturers of insulated tubulars for finished insulated drillpipe designs.

Major Reports to Date:

Finger, J. T., "Drilling Fluid Temperatures In a Magma-Penetrating Wellbore". Transactions of the Geothermal Resources Council Annual Meeting, October, 1986. 
7

$+$

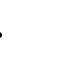


Task: Hard Rock Penetration

Project: Rock Penetration Mechanics

GTD Manager: Lew W. Pratsch

\begin{abstract}
Analysis of Drill String Dynamics
Directing Organization:

Albuquerque Operations Office

P.0. Box 5400

Albuquerque, NM 87115

Contractor:

Sandia National Laboratories

P.0. Box 5800

Albuqueruqe, NM 87185

Project Manager:

George P. Tennyson

Principal Investigator:

James C. Dunn

Telephone: (505) 846-3219(Com)

Telephone: (505) $844-4715(\mathrm{Com})$

Contract Number: 0728.000

Contract Period: 10/17/83-OPEN

Contract Funding: FY $88 \quad \$ 20,000.00$

Description:

To accurately measure the severity of down-hole conditions with the aid of a computer program in order to select the most appropriate wellbore equipment.

Activities/FY88 Milestones:

Collect membership fees and signed User Group Charters from Sandia in order to officially start a user group for the program.

Accomplishments to Date:

Constructed finite-element model of bit/OHA/wellbore interaction.

Experimentally verified calculated values for vibration modes and frequencies in static and rotating Bottom Hole Assemblies.

Participated in cost-shared field test to acquire stress and acceleration data from a near-bit instrument package.

Distributed completed source code tape and Users' Manual to Sandia and four industry co-sponsors. (ARCO, Conoco, Mobil, and BP-America).

Major Reports to Date:

Baird, J. A., et a1, "GEODYN: A Geologic Formation/Drillstring Dymamics Computer Program", Paper No. SPE 13023, 59th Annual Technical Conference and Exhibition of the Society of Petroleum Engineers of AIME, Houston, Texas, September 1984.
\end{abstract}


Stone, C. M., Carne, T. G., and Caskey, B. C., "Qualifications of A Computer Program For Drill String Dynamics". Sandia National Laboratories, Transactions of the Geothermal Resources Council, Vol. 9, August 1985.

Baird, J. A., et al, "User Instruction Manual For GEODYN2: A Geological Formation - Bottom Hole Assembly Dynamic Interaction Finite Element Program". (SAND87-7163), June 1987. 
Task: Hard Rock Penetration

Project: Rock Penetration Mechanics

GTD Manager: Lew W. Pratsch

Coring Technology Development

Directing Organization:

Albuquerque Operations Office P.0. Box 5400

Albuquerque, NM 87115

Contractor:

Sandia National Laboratories

P.0. Box 5800

Albuquerque, NM 87185

Project Manager:

George P. Tennyson

Principal Investigator:

James C. Dunn

Telephone: (505) 846-3219(Com)

Telephone: (505) 844-4715(Com)

Contract Number: 0728.000

Contract Period: 10/17/83-OPEN

Contract Funding: FY $88 \quad \$ 40,000.00$

\section{Description:}

To successfully recover core at reasonable cost from relatively deep $(6000+$ feet $)$ boreholes.

\section{Activities/FY88 Milestones:}

Hold coring technology workshop and identify needed development projects.

Publish results of coring systems study and coring workshop.

Prepare development plans for coring technology projects.

\section{Accompl ishments to Date:}

Completed systems study of concepts for obtaining continuous core in deep thermal regions.

Held Sandia Coring Workshop.

Identified development projects which are key to improving coring capabilities.

Major Reports to Date:

"Coring Deep into Hard Rock Formations", DOE Geothermal Program Review, April 1987.

"Coring in Deep Hard Rock Formations", Sandia Report (In preparation). 
Task: Hard Rock Penetration

Project: Rock Penetration Mechanics

GTO Manager: Lew W. Pratsch

PDC Bit Development

Directing Organization:

Albuquerque Operations office

P.0. Box 5400

Albuquerque, NM $: 87115$

Contractor:

Sandia National Laboratories

P.0. Box 5800

Albuquerque, NM 87185

Project Manager:

George P. Tennyson

Principal Investigator:

James $C$. Dunn

Telephone: (505) 846-3219(Com)

Telephone: (505) $844-4715$ (Com)

Contract Number: 0728.000

Contract Period: 10/17/83-OPEN

Contract Funding: FY $88 \quad \$ 20,000.00$

Description:

To develop polycrystalline diamond compact (PDC) drill bits for use in geothermal drilling projects.

Activities/FY88 Milestones:

Publication of SAND Report on SANDIA's POC development.

Accomplishments to Date:

Developed diffusion bonding technique for attaching cutters to mounting studs; transferred technology to industry.

Developed finite - element model of single cutter moving through rock; model predicted cutter forces as well as stresses in rock and in the cutter itself.

Extensive tests on single PDC cutters to measure cutter forces and friction coefficients.

Laboratory and field tests on full-scale bits to compare wear rates, weights on bit, torques, and rates of penetration.

bit face.

Designed and built bit hydraulic test stand for study of fluid flow across

Demonstrated that high pressure jets impinging ahead of the cutter significantly reduce cutting forces. 
Developed thermal analysis model of a cutter that can be used to predict temperatures in the cutter and to define a critical wearflat temperature that should not be exceeded.

Developed bit performance code that correlates rock properties, cutter placement, and operating parameters to define either an operating condition envelope or an optimum bit design.

Major Reports to Date:

Hoover, E. R., and Pope, E. L., "Failure Mechanisms Of PDC Drill Bits In Geothermal Environments". (SAND81-1404), Sandia National Laboratories, September 1981.

Hibbs, L. E., and Sogoian, "Wear Mechanisms For Polycrystalline Diamond Compacts As Utilized For Drilling In Geothermal Environments - Final Report". (SAND82-7213), Sandia National Laboratories, May 1983.

Glowka, D. A., and Stone, C. M., "The Thermal Response of Polycrystalline Diamond Compact Cutters Under Simulated Downhole Conditions". Paper No. SPE 11947 , 58th annual Technical Conference and Exhibition of the Society of Petroleum Engineers of AIME, San Francisco, Cald fornia, October 1983.

Glowka, D. A., and Stone, C. M., "Effects of Thermal and Mechanical Loading on POC Bit Life". Sandia National Laboratories, Paper No. SPE 13257, 59th Annual Technical Conference and Exhibition of the Society of Petroleum Engineers of AIME, Houston, Texas, September 1984.

Glowka, D. A., "Design Considerations For A Hard-Rock PDC Drill Bit". Sandia National Laboratories, Transactions of 1985 Annual Meeting of Geothermal Resources Council, Vol 9-Part I, August 1985.

Glowka, D. A., "Implications of Thermal Wear Phenomena For PDC Bit Design and Operation". Sandia National Laboratories, Paper No. SPE 14222, 60th Annual Technical Conference and Exhibition of the Society of Petroleum Engineers, Las Vegas, Nevada, September 1985.

Glowka, D. A., "Development of A Method For Predicting The Performance And Wear of PDC Drill Bits". (SAND86-1745), Sandia National Laboratories, June 1987.

Ortega, A., Glowk, D.A., "Frictional Heating and Convective Cooling of Polycrystalline Diamond Drag Tools During Rock Cutting". Sandia National Laboratories, Society of Petroleum Engineers Journa1, April 1984.

Zeuch, O.H., and Finger, J.T., "Rock Breakage Mechanisms with a PDC Cutter". Sandia National Laboratories, Paper No. SPE 14219, 60th Annual Technical Conference and Exhibition of the Society of Petroleum Engineers, Las Vegas, NV. September 1985. 
Task: Hard Rock Penetration

GTD Manager: Lew W. Pratsch

Project: Instrumentation

\section{Acoustical Data Telemetry}

Directing Organization:

Albuquerque Operations office

P.0. Box 5400

Albuquerque, NM :87115

Contractor:

Sandia National Laboratories

P.0. Box 5800

Albuquerque, NM 87185

Project Manager:

George P. Tennyson

Principal Investigator:

James C. Dunn

Telephone: (505) 846-3219(Com)

Telephone: (505) 844-4715(Com)

Contract Number: 0728.000

Contract Period: 10/17/83-OPEN

Contract Funding: FY $88 \quad \$ 250,000.00$

Description:

The objective of this project is to produce a reliable method for collecting the telemetry of data at the drill bit in order to reduce well costs and increase production. The collecting method currently being investigated is the recording and analysis of acoustical carrier waves transmitted through the drill string.

Activities/FY88 Milestones:

Complete analysis and issue a technical publication.

Complete construction of laboratory model and collect preliminary data on echoing and wave dispersion.

Issue technical publication on laboratory work.

Design comprehensive field tests.

Accomplishments to Date:

Theory completed; concept verified with analysis of field test.

Scale model constructed as testbed for transducers.

Patent disclosure submitted.

Technology transfer effort initiated.

Model transducers designed - fabrication in progress. 


\section{Major Reports to Date:}

Drumheller, D. S., "Acoustical Properties of Drill Strings Part I: Theory". Journal of Acoustical Society of America, (in review).

Drumheller, D. S., "Acoustical Properties of Drill Strings Part II: Analysis of a Field Test". Journal of Acoustical Society of America, (in review).

Drumheller, D. S., "Acoustical Properties of Drill Strings Part III: Experiment". Journal of Acoustical Society of America, (in review). 
Task: Hard Rock Penetration

GTD Manager: Lew W. Pratsch

Project: Instrumentation

\section{Radar Fracture Mapping Tool}

Directing Organization:

Albuquerque Operations office P.0. Box 5400

Albuquerque, NM 87115

Project Manager:

George P. Tennyson

Telephone: (505) 846-3219(Com)

Contract Number: 0728.000

Contract Funding: FY $88 \quad \$ 430,000.00$
Contractor:

Sandia National Laboratories

P.0. Box 5800

Albuquerque, NM 87185

Principal Investigator:

James C. Dunn

Telephone: (505) 844-4715(Com)

Contract Period: 10/17/83-OPEN

\section{Description:}

To build a wireline radar fracture mapping tool.

Activities/FY88 Milestones:

Complete mechanical design modifications and add a $5 \mathrm{kw}$ transmitter.

Establish an in-house calibration facility.

Complete field testing of prototype tool in a rock quarry.

Report test results and evaluate performance of prototype tool.

Accompl ishments to Date:

\section{Major Reports to Date:}

Bauman, T. J., "A Geothermal Lost Circulation Zone Mapping Tool", Sandia National Laboratories, Transactions of 1985 Annual Meeting of Geothermal Resources Counci1, Vo1. 9-Part 11, August 1985.

Chang, H.T., "Feasibility of A Borehole VHF Radar Technique For Fracture Mapping". Sandia National Laboratories, Transactions of 1984 Annual Meeting of the Geothermal Resources Council. Vol. 9-Part II. August 1985. 
Chang, H.T., "Feasibility of An Acoustic Technique For Fracture Detection". Sandia National Laboratories, Transactions of 1985 Annual Meeting of Geothermal Resources Council. Vol. 9-Part II, August 1985.

Chang, H.T., "A Downhole Radar System For Fracture Detection". Sandia National Laboratories, Transactions of 1986 Annual Meeting of Geothermal Resources Counci1, Vol. 10, 1986. 
Task: Hard Rock Penetration GTD Manager: Lew W. Pratsch

Project: Geothermal Drilling Organization

\section{Borehole Televiewer}

Directing Organization:

Albuquerque Operations office

P.0. Box 5400

Albuquerque, NM 87115

\section{Contractor:}

Sandia National Laboratories

P.0. Box 5800

Albuquerque, NM 87185

Project Manager:

George P. Tennyson

Principal Investigator:

James C. Dunn

Telephone: (505) 846-3219(Com)

Telephone: (505) 844-4715(Com)

Contract Number: 0728.000

Contract Period: 10/17/83-OPEN

Contract Funding: FY $88 \quad \$ 90,000.00$

1

Description:

The objective of this project is to develop a commercially available acoustic borehole televiewer for use in geothermal wells.

Activities/FY88 Milestones:

Complete hot test of televiewer in geothermal well.

Place contract for logging phase of televiewer development.

Obtain field data in geothermal wells.

Accomplishments to Date:

\section{Major Reports to Date:}

Heard, F. E., and Bauman, T. J., "Development of A Geothermal Acoustic Borehole Televiewer". (SAND83-0681), Sandia National Laboratories, August 1983. 


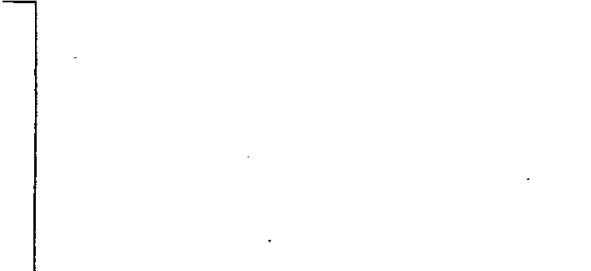

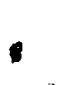$$
\cdot
$$ 
Task: Hard Rock Penetration

Project: Geothermal Drilling Organization

GTD Manager: Lew $W$. Pratsch

\section{High Temperature Elastomer Development}

Directing Organization:

Albuquerque Operations office P.0. Box 5400

Albuquerque, NM :87115

Project Manager:

George P. Tennyson

Telephone: (505) 846-3219(Com)

Contract Number: 0728.000

Contract Funding: FY $88 \quad \$ 30,000.00$
Contractor:

Sandia National Laboratories

P.O. Box 5800

Albuquerque, NM 87185

Principal Investigator:

James C. Dunn

Telephone: (505) 844-4715(Com)

Contract Period: 10/17/83-OPEN

\section{Description:}

The objective of this project is to develop high temperature elastomers that will extend the life, and improve the performance, of geothermal drilling equipment.

\section{Activities/FY88 Milestones:}

Place contract for the development of drill pipe protectors.

Place contract for the development of rotating head seals.

Place contract for the development of BOP rubbers.

Test drill pipe protectors in geothermal wells.

Accomplishments to Date:

\section{Major Reports to Date:}

Carson, C. C., "Geothermal Instrumentation Development Activities at Sandia". Sandia National Laboratories, Transactions of 1985 Annual Meeting of Geothermal Resources Council, Vol. 9-Part II, August 1985. 
Task: Hard Rock Penetration GTD Manager: Lew W. Pratsch

Project: Geothermal Drilling Organization

Foam Lost Circulation Tool

Directing Organization:

A1buquerque Operations office

P.0. Box 5400

Albuquerque, NM 87115

Project Manager:

George P. Tennyson

Telephone: (505) 846-3219(Com)

Contract Number: 0728.000

Contract Funding: FY $88 \quad \$ 7,000.00$
Contractor:

Sandia National Laboratories

P.0. Box 5800

Albuquerque, NM 87185

Principal Investigator:

James C. Dunn

Telephone: (505) 844-4715(Com)

Contract Period: 10/17/83-OPEN

\section{Description:}

The objective of the Foam Lost Circulation Tool project is to develop both an expanding foam for plugging lost circulation zones and the tool for applying it.

Activities/FY88 Milestones:

Complete field testing of Foam Lost Circulation Tool.

Accomplishments to Date:

\section{Major Reports to Date:}

Blackwell, B. F., and Ortega, A., "A Quasi-Steady Model For Predicting Temperature of Aqueous Foams Circulating In Geothermal Wellbores". (SAND82-0899C), Sandia National Laboratories, July 1983.

Kraynik, A. M., "Foam Drainage". (SAND83-0844), Sandia National Laboratories, November 1983.

Loeppke, G. E., Polk, G., Baughman, K., "Self-Contained, Rigid-Foam Placement Tool For Plugging Lost-Circulation Zones". Transactions of 1985 Annual Meeting of the Geothermal Resources Council, Vol. 9-Part I, August 1985. 


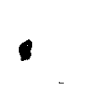


Task: Hard Rock Penetration GTD Manager: Lew W. Pratsch Project: Geothermal Drilling Organization

\footnotetext{
Downhole Air Turbine

Directing Organization:

Albuquerque Operations offic

P.0. Box 5400

Albuquerque, NM : 87115

Contractor:

Sandia National Laboratories

P.0. Box 5800

Albuquerque, NM 87185

Project Manager:

George P. Tennyson

Principal Investigator:

James C. Dunn

Telephone: (505) 846-3219(Com)

Telephone: (505) 844-4715(Com)

Contract Number: 0728.000

Contract Period: 10/17/83-OPEN

Contract Funding: FY $88 \quad \$ 23,000.00$

Description:

The objective of the Downhole Air Turbine project is to develop a downhole air turbine for drilling geothermal wells.

Activities/FY88 Milestones:

Complete first phase field test in the Geysers.

Complete final field tests in the Geysers.

Accomplishments to Date:
}

Major Reports to Date: 

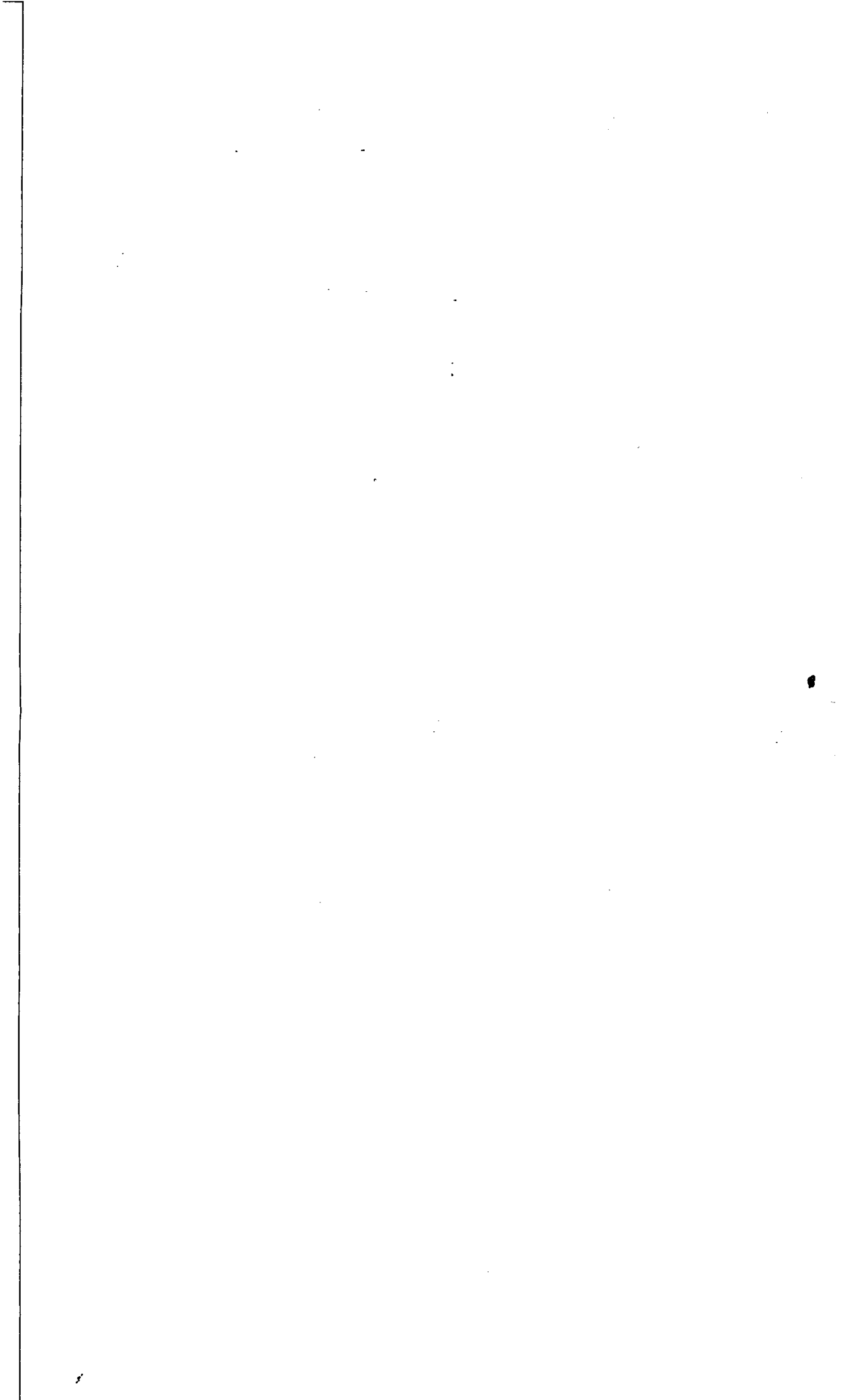

84

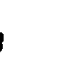

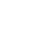

, 


\subsection{Conversion Technology}

Status

Description a. Heat Cycle Research: Large binary technology has been tested at the government/ industry 45-MWe plant in Heber, California. The costs of this research project are subeconomic for commercial application at this time.

b. Advanced Brine Chemistry: Enough has been learned about the complex chemistry of brines that it should be possible to identify cost-effective power cycles, equipment, and materials when a brine falls within well-defined chemical, experience, and technical bounds found at other sites. Brine-related problems are still a costly cause of undue maintenance requirements and downtime.

c. Materials Development: While considerable progress has been made in materials developed to withstand the hot, hostile geothermal environment, the expected iffetimes of certain surface and downhole components are not yet cost-effective.

Because of the variable nature of geothermal energy, a variety of technologies are used to convert its heat to electricity. Dry steam conversion technology is mature and has been in commercial use for many years. The basic technology for flash steam plants is also well advanced, and at today's state-of-the-art, is usually used when the resource temperature is over $200^{\circ} \mathrm{C}\left(400^{\circ} \mathrm{F}\right)$. Binary cycles are more thermodynamically efficient than flash cycles in the $150-200^{\circ} \mathrm{C}\left(300-400^{\circ} \mathrm{F}\right)$ range. The larger size and higher costs of equipment required for lower temperature fluids, and the tendency of some brines to foul binary cycle heat exchangers and downhole pumps, have inhibited the use of binary systems in all but small units. R\&D is underway in which advancements in binary technology will permit it to efficiently operate than flash steam technology on the more abundant moderate-temperature reservoirs.

Other areas of major concern to geothermal power producers are the problems associated with 
handling highly saline brines within production wellbores, wellfield pipelines and steam separators, power plant plumbing and valves, and injection wells. Many costly problems are caused by precipitation of hard mineral scales from supersaturated brine as temperature falls and acidity changes with loss of dissolved carbon dioxide. In fact, mineral scaling is the dominant cause of increased costs associated with the operation of geothermal power plants that use highly saline hot brine reservoirs.

Another major problem related to brine chemistry, as well as to high temperatures, is the extraordinary demand these factors make on materials commoniy used in other industries. The combined effects of thermal stress and corrosion and scaling on equipment and components limit their durability to such a degree that plant availability, lifetime, power output, and heat exchange capability may be seriously affected. Any of these problems decrease the cost-effectiveness of the operation through downtime and costly replacement.

The Program's heat cycle task is focused on the development of technology for effecting the improved utilization of moderate-temperature geothermal fluids. A major emphasis of the research, as suggested above, is improvement of the performance of geothermal binary cycles to levels approaching the practicable thermodynamic maximum. In pursuit of this goal, tests are being conducted at the Heat cycle Research Facility located at East Mesa, California. The current testing involves the investigation of binary power cycle performance utilizing mixtures of nonadjacent hydrocarbons as the working fluids, with supercritical vaporization and intube condensation of the working fluid. In addition to the present program, preparations are being made to investigate the binary cycle performance improvements which can be achieved by allowing supersaturated vapor expansions in the turbine. These efforts are anticipated to verify that through the utilization of these advanced power cycle concepts and allowing the supersaturated turbine expansions, improvements of up to 28 percent in the net geofluid effectiveness (net watt hours plant output per pound of geofluid) over conventional binary power plants can be achieved. Results of recent testing, including those tests examining the performance of the countercurrent condenser at different tube 
inclinations, support the assumptions used in projected performance improvements.

Future efforts will include examination of those concepts which will allow the base of resources that can be economically developed to be expanded through the use of innovative technology. Specific areas for investigation include heat rejection systems which will minimize the cooling water make-up requirements while retaining performance approaching that of conventional wet cooling systems.

Two approaches are being pursued to define the expensive operating problems associated with brine chemistry. First, numerical modeling of complex brines will allow improved prediction of the thermodynamic conditions under which problems occur in geothermal power plants from scale deposition, corrosion, and suspended solids. These predictions will in turn allow engineering design, material selection, and power plant operations to be modified to optimize the economic utilization of the resource.

Second, research is focused on detection and monitoring of constituents in the brine stream which can damage piping, valves, and wells as brine flows through the power plant and is injected back into the wellfield. Chemistrymonitoring instrumentation is inserted in the brine flow lines to detect serious corrosion, scaling, and particulate matter before these problems result in plant failure.

Another major problem engendered in geothermal development due to brine chemistry is the large volume of sludge created by treatment of hypersaline brines prior to injection. This step is necessary to avoid plugging of the injection well, but the resulting siudge is contaminated with trace toxic constituents of the brine itself, such as mercury, lead, and vanadium. The presence of these metals, though small in quantity, invokes federal/state environmental regulations requiring disposal in sites licensed to receive hazardous wastes. Before large scale development of hypersaline brines can occur, environmentally and economically acceptable methods for disposing of the wastes must be found.

Experiments are underway on the use of biochemical techniques to concentrate and remove 
toxic metals from wastes. There are several mechanisms by which micro-organisms react with metals. Two mechanisms are being addressed. One method is the solubilization of metals by microorganisms which leach out the metals; and the other is concentration and removal of the metals by their sorption on cellular materials. Both processes are applicable in situations where metals are present in large volumes of waste at concentrations unsuitable for conventional technology.

Geothermal materials development was initiated early in the Program to ensure that the private sector development of geothermal energy is not constrained by the availability of technologically and economically viable materials of construction. Major successes have been attained in the development of elastomers for high-temperature applications and in the use of polymer concrete liners for corrosion protection.

The development of the high-temperature $Y$ 267 EPDM (ethylene, propylene, diene, methylene) elastomer can be classified as a technology breakthrough. Used in seals for well logging tools, packers, valves, and other equipment exposed to hostile high-temperature environments, the Y-267 EPDM elastomer has proven to be at the leading edge of technology. Tests performed for applications in the oil, gas, nuclear, and coal industries have given equally impressive results.

Cements represent another area where considerable progress has been made. The cementing of a well is considered to be one of the most critical items in geothermal development. 
Task: Conversion Technology

GTO Manager: Raymond LaSala

Project: Heat Cycle Research

\section{Advanced Heat Rejection System}

Directing Organization:

Idaho Operations office

550 2nd Street

Idaho Falls, ID : 83401

Project Manager:

Kenneth Taylor

Telephone: (208) 526-9063(Com)

583-9063 (FTS)

Contract Number: 7AC111

Contract Funding: FY $88 \quad \$ 65,000.00$

\author{
Contractor: \\ Idaho National Engineering Lab. (EG\&G) \\ P.0. Box 1625 \\ Idaho Falls, ID 83415 \\ Principal Investigator: \\ G. L. Mines
}

Telephone: (208) 526-0260(Com)

Contract Period: 06/01/88-Open

Description:

As part of the overall task objective of identifying, developing and applying new technologies for energy conversion systems the objective of the Advanced Heat Rejection task is to analyze and test condenser/cooling systems that have a lower requirement for clean make-up cooling water.

Activities/FY88 Milestones:

Complete system study for the advanced heat rejection system.

Complete research and report results for advanced heat rejection system. Accomplishments to Date:

\section{Major Reports to Date:}

Bliem, C. J., "Preliminary Performance Estimates of Binary Geothermal Cycles Using Mixed-Halocarbon Working Fluids". July 1986.

Jacobs, H. R., and Eden, T. J., "Direct Contact Heat Transfer In A Sieve Tray Column". Eighth International Heat Transfer Conference, August 1986.

Bliem, C. J., et al, "Vaporization at Supercritical Pressures and Counterflow Condensing of Pure and Mixed-Hydrocarbon Working Fluids for Geothermal Power Plants". 21st Intersociety Energy Conversion Engineering Conference, August 1986. 
Bliem, E. J., "Zeotropic Mixtures of Halocarbons as Working Fluids in Binary Geothermal Power Generation Cycles". 22nd Intersociety Energy Conversion Engineering Conference, August 1987. 
Task: Conversion Technology

GTD Manager: Raymond LaSala

Project: Heat Cycle Research

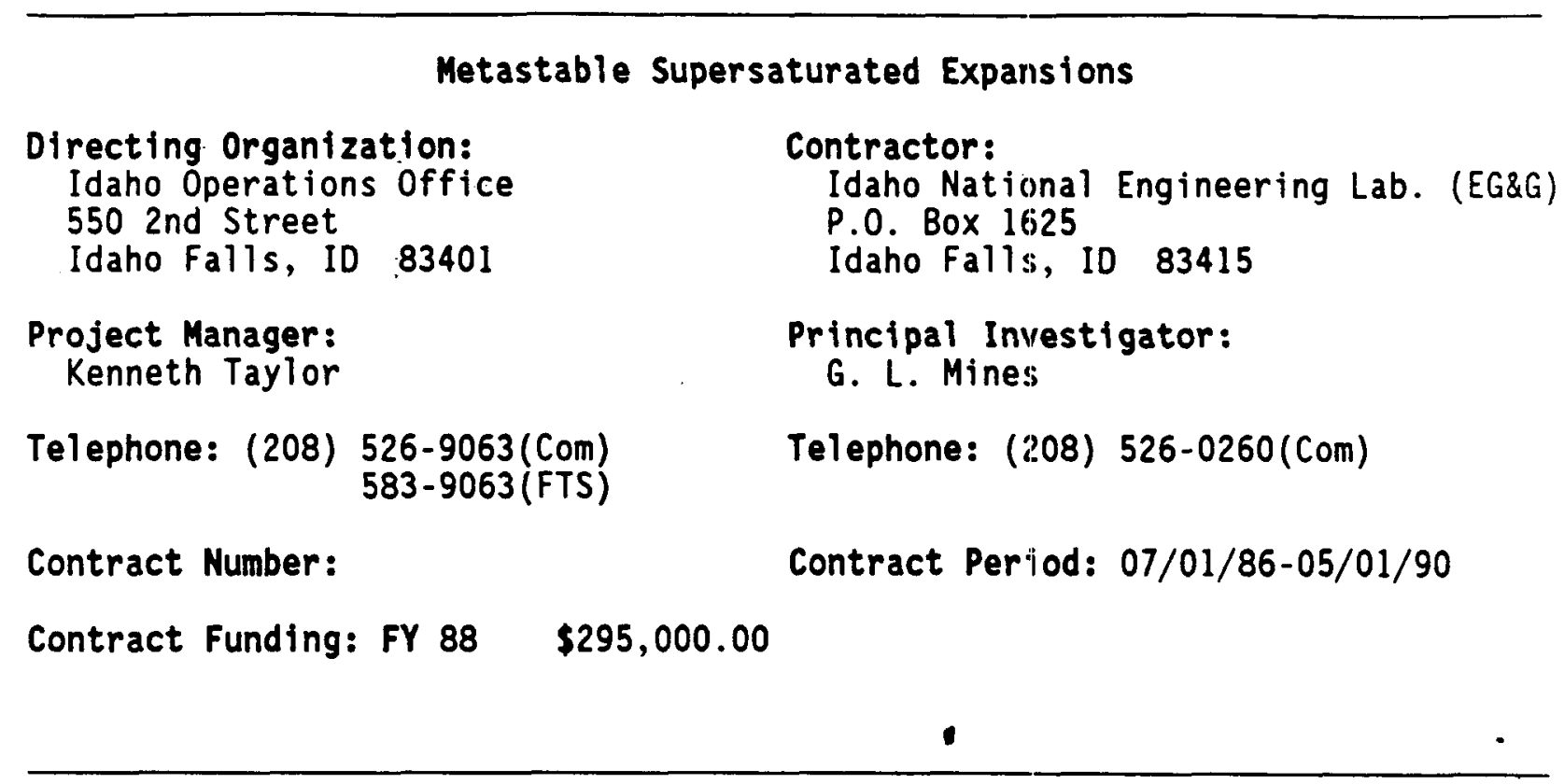

Description:

The Metastable Supersaturated Expansions project: seeks to establish the degree of wetness that can be tolerated in hydrocarbon vapor expansions in radial. inflow reaction turbines.

\section{Activities/FY88 Milestones:} system.

Complete the development and procurement of laser droplet illumination

Specify and receive a reaction turbine for testing of HCRF. turbine.

Complete the design of facility modifications for 2-D nozzle and reaction

Install the 2-D nozzle and reaction turbine at HCRF. results.

Complete testing of metastable supersaturated vapor expansions; report

\section{Accomplishments to Date:}

NCA\&T developed and procured a LASER droplet illumination system to be utilized with a two-dimensional nozzle in determining whether condensate forms in the metastable supersaturated expansions.

Specified a new reaction turbine for testing at the HCRF. 


\section{Major Reports to Date:}

Mines, G. L., and Bliem, C. J., "Effects of Mixtures and Supersaturated Turbine Expansions on Turbine Efficiency".

Bliem, C. J., Mines, G. L., Goswami, D. Y., "Investigation of Condensation Behavior of Metastable Supersaturated Vapor Expansions of Hydrocarbon Working Fluids". 
Task: Conversion Technology

GTO Manager: Raymond LaSala

Project: Heat Cycle Research

\section{Condenser Attitude Tests}

Directing Organization: Idaho Operations office 550 2nd Street Idaho Falls, ID :83401

Project Manager: Kenneth Taylor

Telephone: (208) 526-9063(Com) $583-1147$ (FTS)

Contract Number: TAC111

Contract Funding: FY $88 \quad \$ 75,000.00$
Contractor:

Idaho National Engineering Lab. (EG\&G) P.0. Box 1625

Idaho Falls, ID 83415

Principal Irivestigator:

G. L. Mine:s

Telephone: (208) 526-0260(Com)

Contract Period: 07/01/88-02/01/90

\section{Description:}

The objective of the Condenser Attitude Tests piroject is to characterize the performance of counterflow, in-tube condensers in a variety of operating conditions.

\section{Activities/FY88 Milestones:}

Complete supercritical testing with condenser criented at final attitude with the isobutane-hexane family. report.

Complete supercritical cycle testing at final condenser attitude; prepare

Procure the reaction turbine.

Specify necessary instrumentation for two dimensional nozzle testing.

Prepare test plan for conducting two dimensional nozzle and reaction turbine testing.

Design the facility modifications to install the two dimensional test nozzle and reaction turbine.

Incorporate the testing of the two dimensional expansion nozzle and the reaction turbine into the supercritical cycle testing at the final condenser attitude. 


\section{Accomplishments to Date:}

The accomplishments of the Heat Cycle Research Facility, HCRF, may also be accredited to the Condenser Attitude Test project as the condenser is part of HCRF.

The data collected at the near horizontal condenser attitude was evaluated in sufficient detail to assist in the identification of the final condenser attitude to be tested, as well as to determine the adequacy of the data being generated by the testing.

\section{Major Reports to Date:}

Bliem, C. J., Mines, G. L., Swank, W. D., "Geothermal Heat Cycle Research--Supercritical Cycle with Horizontal Counterflow Condenser". 22nd Intersociety Energy Conversion Engineering Conference, August 1987.

Bliem, C. J., Mines, G. L., "Countercurrent Flow, In-Tube Condensing Characteristics of Binary Hydrocarbon Mixtures at Three Condenser Attitudes". 
Task: Conversion Technology

GTD Manager: Raymond LaSala

Project: Heat Cycle Research

$\begin{array}{lc} & \text { Systems Analysis } \\ \text { Directing Organization: } & \text { Contractor: } \\ \text { Idaho Operations Office } & \text { Idaho National Engineering Lab. (EG\&G) } \\ 550 \text { 2nd Street } & \text { P.O. Box 1625 } \\ \text { Idaho Fal1s, ID } 83401 & \text { Idaho Falls, ID } 83415 \\ \text { Project Manager: } & \text { Principal Investigator: } \\ \text { Kenneth Taylor } & \text { G. L. Mines } \\ \text { Telephone: (208) } 526-9063 \text { (Com) } & \text { Telephone: (208) 526-0260(Com) } \\ \text { Contract Number: } 7 A C 111 & \text { Contract Period: } 10 / 01 / 85-12 / 01 / 88 \\ \text { Contract Funding: } & \end{array}$

Description:

The objective of the Systems Analysis project is to analyze the theoretical and emperical performance of the various heat cycles and components under investigation.

Activities/FY88 Milestones:

Complete conceptual design and analysis of combined direct-contact heat exchanger and crystallizer; prepare report.

Complete preliminary estimate of binary geothermal cycle preformance using mixed-fluorocarbon or halocarbon working fluids and of applicability of modified Kalina Cycles; prepare report.

Accomplishments to Date:

The advanced binary system analysis focused on the completion of the evaluation of the Kalina Cycle for geothermal applications. Specifically INEL evaluated whether the potential gains from the Kalina Cycle offset the increased complexity of the system imposed by utilizing the Kalina cycle.

\section{Major Reports to Date:}

Bliem, C. J., "Kalina Cycles for Geothermal Power Production". May 1986. 


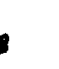

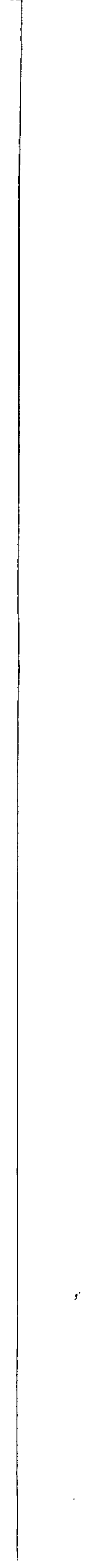

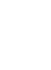


Task: Conversion Technology

GTD Manager: Raymond LaSala

Project: Heat Cycle Research

\section{Heat Cycle Research Facility Testing}

Directing Organization:

Idaho Operations office

550 2nd Street

Idaho Falls, ID 83401

Project Manager:

Susan Prestwich

Telephone: (208) 526-1147(Com)

$583-1147$ (FTS)

Contract Number: 7AC111

Contract Funding: FY $88 \$ \$ 430,000.00$
Contractor:

EG\&G Idaho Inc.

P.0. Box 1625

Idaho Falls, ID 83415

Principal Investigator:

G. L. Mines

Telephone: (208) 526-0260(Com)

Contract Period: 09/01/85-12/01/88

Description:

The HCRF project has two main objectives. These are:

1) To develop high performance Rankine or Kalina cycles for moderate and/or high salinity resources, which are beyond the current state-of-the art, and which would result in net plant geofluid effectiveness increases of up to $28 \%$ relative to state-of-the-art technology plants.

2) To develop heat cycle working fluids with improved heat transfer and/or energy characteristics such as isobutane-hexane, R22-R114, or propane-benzene mixtures.

\section{Activities/FY88 Milestones:}

Complete supercritical cycle testing with impulse turbine, and report results on effects of mixtures and supersaturated turbine expansions on turbine efficiency.

Relocate the HCRF to an alternate location, in California's Imperial Valley. INEL and DOE-ID will identify the next test location and will negotiate an agreenent with the owner which will allow the HCRF to operate at this site.

Install a two dimensional expansion nozzle and a reaction turbine during the relocation.

Evaluate data collected at the vertical and near vertical condenser positions to determine the effect of condenser orientation on the performance as well as adequecy of design methods. 
Complete preliminary estimates of binary cycle performance with mixed-fluorocarbon working fluids and the applicability of utilizing the modified Kalina cycle.

Accompl ishments to Date:

The operation of the Heat Cycle Research Facility, (HCRF), at the DOE Geothermal Test Facility has most recently yielded the following results (FY87):

- The testing of the HCRF at the near horizontal condenser attitude was completed with both the propane-isopentane and the isobutane-hexane working fluid families.

- The HCRF was modified to orient the condenser at the final attitude to be tested; an intermediate inclination, 60 degrees off the horizontal. Testing was then resumed using the isopentane working fluid family.

\section{Major Reports to Date:}

Bleim, C.J., et al. "Vaporization at Supercritical Pressures and Counterflow Condensing of Pure and Mixed-Hydrocarbon Working Fluids for Geothermal Power Plants". 21st Intersociety Energy Conversion Engineering Conference. August 1986.

Bliem, C.J., "Zeotropic Mixtures of Halocarbons as Working Fluids in Binary Geothermal Power Generation Cycles". 22nd Intersociety Energy Conversion Engineering Conference. August 1987.

Goswami, D.Y., and Sharpe, L., "Evaluation of Thermal Performance of Direct Contact Heat Exchangers for Vaporizing Mixed Hydrocarbon Working Fluids ". May 1986.

Goswami, D.Y., Sharpe, L., Hingorani, S., "Analysis of Tray Thermal Efficiencies of Direct Contact Heat Exchangers for Vaporizing Hydrocarbon Mixtures". ASME/JSME Thermal Engineering. Joint Conference. March 1987.

Jacobs, H.R., "Continued Research on Direct Contact Heat Exchangers Effects of Crystallization". July 1987. 
Task: Conversion Technology

Project: Materials Research

GTD Manager: Raymond LaSala

\section{Advanced High Temperature Cements}

Directing Organization:

San Francisco Operations Office

1333 Broadway

Oakl and, CA 94612

Contractor:

Associated Universities, Inc.

Brookhaven National Laboratory

Upton, NY 11973

Project Manager:

Martin W. Molloy

Telephone: (415) 273-7945(Com)

536-7945 (FTS)

Principal Investigator:

Lawrence E. Kukacka

Telephone: (516) 666-3065(Com)

$666-3065$ (FTS)

Contract Number: AS-17-PSD

Contract Period: 04/01/88-09/01/88

Contract Funding: FY $88 \$ \$ 360,000.00$

Description:

The purpose of this project is to improve the durability of cement exposed to a high temperature environment.

Activities/FY88 Milestones:

Complete 1 year downhole exposure test at 300 degree $C$.

Complete property measurements.

Issue Annual Report.

Accompl ishments to Date:

Cements developed that can withstand 250 degree $C$.

Major Reports to Date:

Milestine, N.B., Kukacka, L.E., Sugama, T., and Carciello, N., "Effects of Carbon Dioxide Attack on Geothermal Cement Grouts". Transactions of Geothermal Resources Council 1986 Annual Meeting. Palm Springs, California. September, 1986.

Sugama, T., Kukacka, L.E., and Galen, B.G., "Advanced High-Temperature Light Weight Foamed Cements for Geothermal Completions". Transactions of Geothermal Resources Council 1986 Annual Meeting. Palm Springs, California. September 1986. 
Task: Conversion Technology

Project: Materials Research

\footnotetext{
Very High Temperature Well Completion Materials

Directing Organization:

San Francisco Operations office

1333 Broadway

Oakl and, CA 94612
Contractor:
Associated Universities Inc.
Brookhaven National Laboratory
Upton, NY 11973

Project Manager:

Martin W. Molloy

Principal Investigator:

Lawrence E. Kukacka

Telephone: (415) 273-7945(Com)

Telephone: (516) 666-3065(Com)

Contract Number: AS-17-PSD

Contract Period: 07/01/88-09/01/88

Contract Funding:

Description:

The objective of this project is to design durable cost-effective materials of construction for geothermal energy processes.

Activities/FY88 Milestones:

Identify potential systems of interest.

Complete short-term property measurements.

Accomplishments to Date:

Downhole testing of 300 degree C lightweight cements underway in New Zealand as part of a cost-shared effort with Department of Scientific and Industrial Research.

Major Reports to Date:

None.
} 
7

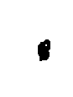

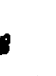
$\cdot$ 
Task: Conversion Technology

GTD Manager: Raymond LaSala

Project: Materials Research

\section{Non-Mettalic Heat Exhanger Tubing}

Directing Organization:

San Francisco Operations Office 1333 Broadway

Oakland, CA 94612
Contractor:
Associated Universities, Inc.
Brookhaven National Laboratory
Upton, NY 11973

Project Manager:

Martin W. Molloy

Principal Investigator:

Lawrence E. Kukacka

Telephone: (415) 273-7945(Com)

Telephone: (516) 666-3065(Com)

Contract Number: AS-17-PSD

Contract Period: 10/01/87-09/01/88

Contract Funding:

\section{Description:}

To develop low cost thermally conductive and corrosion resistant tubing for the binary process.

Activities/FY88 Milestones:

Select a location of an industry test site.

Complete prototype unit design.

Complete construction of the prototype unit.

Commence field testing.

Accompl ishments to Date:

Conducted measurements of thermal conductivity.

Established wall thickness requirements.

Developed prototype tubes for corrosion rate, scaling factor, and heat transfer measurements.

Major Reports to Date:

None. 


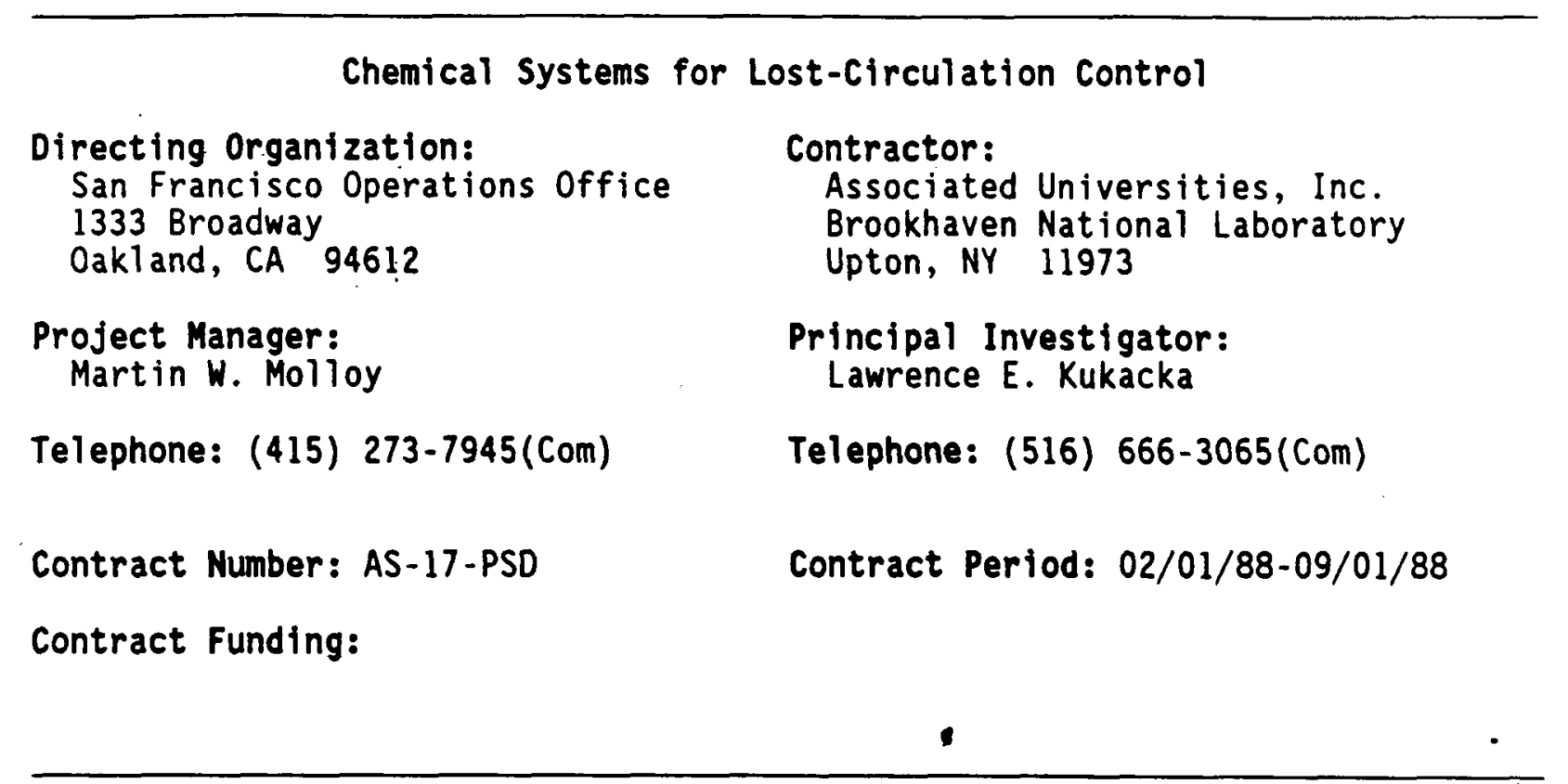

Description:

This project seeks to develop particulate-filled high-temperature lightweight (approx. $1 \mathrm{gm} / \mathrm{cc}$ ) materials to reduce the frequencey of lost-circulation problems during drilling and well completion operations.

Activities/FY88 Milestones:

Complete laboratory optimization studies on particulate-filled systems.

Complete slot testing.

Complete large-scale flow test at the Sandia Lost Circulation Facility. Accomplishments to Date:

Systems have been tested successfully at $<200$ degrees $C$. Major Reports to Date:

Sugama, T., Kukacka, L. E., Warren, J. B., and Galen, B. G., "Bentonite-based ammonium polyphosphate cementitious lost-circulation control materials". Journal of Material Science. 21, 2159-68 1986.

Sugama, T., Kukacka, L. E., Galen, B. G., and Milestone, N. B., "Characteristics of high temperature cementitious lost-circulation control materials for geothermal wells". Journal Of Material Science, in press. 
Task: Conversion Technology

Project: Advanced Brine Chemistry

GTD Manager: Gladys Hooper

Advanced Monitoring Instruments

Directing Organization:

Pacific Northwest Laboratory

P.0.Box 999 Battelle Boulevard

Richl and, WA 99352

Project Manager:

Donald R. Segna

Telephone: (509) 444-8989(Com)

Contract Number:

Contract Funding: FY $88 \quad \$ 105,000.00$

\author{
Contractor: \\ Battelle Memorial Institute (PNL) \\ Battelle Boulevard \\ Richland, WA 99352 \\ Principal Investigator: \\ Donald W. Shannon
}

Telephone: (509) 444-3139(Com)

Contract Period: 10/01/79-OPEN

Description:

Development, testing, and application of advanced process chemistry techniques for in-line monitoring at geothermal power plants.

Activities/FY88 Milestones:

Conduct laboratory tests of prototype laser and ultrasonic particle meters using a high-temperature, high-pressure synthetic brine set-up at Pacific Northwest Laboratory prior to field tests.

\section{Accompl ishments to Date:}

Developed and/or tested the following in-line monitoring instruments since the program began in 1979:

- Leak detectors for brine, hydrocarbon, and cooling water systems;

- Electrodeless conductivity probe to monitor brine quality and detect gases;

- Redox meter (ORP) to detect air intrusions;

- State-of-the-art $\mathrm{pH}$ meters to monitor the acidity that affects both corrosion and scaling; and

- Particle counters to monitor solids that could plug injection wells.

Completed a two-year cooperative testing program with Magma Electric Company at Magma's East Mesa power plant in which some serious chemical problems were detected before plant failure. 
Developed an in-line monitoring system for the Heber Binary power plant based on field monitoring experience at the East Mesa plant

Entered into a Site Assessment Agreement with San Diego Gas and Electric Company, and carried out a host of process chemistry experiments at the Heber plant.

Developed experimental data to test a geothermal brine computer model being developed by the University of California at San Diego.

Assembled and published a comprehensive handbook of brine treatment processes and other factors associated with injection well longevity.

\section{Major Reports to Date:}

Robertus, R. J., Shannon, D. W. and Sullivan, R. G. "Report on Design, Construction and Testing of $\mathrm{CO} 2$ Breakout System for Geothermal Brines". PNL-5042, Pacific Northwest Laboratory, Richland, Washington, March 1984.

Robertus, R. J., Sullivan, R. G. and Shannon, O.'W. "Operating Manual for Water in Hydrocarbon Leak Detector". PNL-5043, Pacific Northwest Laboratory, Richland, Wahington, April 1984.

Robertus, R. J., Shannon, D. W., Sullivan, R. G. and Pool, K. H., "Operating Manual for Hydrocarbon in Water Leak Detector". PNL- 5132, Pacific Northwest Laboratory, Richland, Washington, June 1984.

Robertus, R. J., Shannon, D. W., and Sullivan, R. G. "Special Function Instruments for Binary Cycle Geothermal Power Plants". Geothermal Resources Council Transactions, Vo1. 8, pp. 93-97, August, 1984.

Robertus, R. J., Pool, K. H., Kindle, C. H., Sullivan, R. G., Shannon, D. W., and Pierce, D. D. "Leak Detectors for Organic Rankine Cycle Power Plants: On-Line and Manual Methods". PNL-5261, Pacific Northwest Laboratory, Richland, Washington, October, 1984.

Robertus, R. J., Shannon, D. W., Sullivan, R. G., Kindle, C. H., and Pool, K. H. "Research on Geothermal Chemistry and Advanced Instrumentation". PNL-SA-13397. Proceedings of Fourth Annual DOE Geothermal Program Review, Washington, D.C. September 11-12, 1985.

Robertus, R. J., et al. "Field Tests of Corrosion and Chemical Sensors for Geothermal Power Plants". PNL-5782, Pacific Northwest Laboratory, Washington, March, 1986.

Robertus, R. J., Sullivan, R. G., and Shannon, D. W. "Scaling Tendency of Some Moderate Temperature Geothermal Brines". PNL-5991, Pacific Northwest Laboratory, Richland, Washington, September, 1986.

Pool, K.H., Raney, P.J., and Shannon, D.W., "Calcite Solubility in Simulated Geothermal Brines". PNL-6157. Pacific Northwest Laboratory. Richland Washington. February 1987. 
Task: Conversion Technology

Project: Advanced Brine Chemistry

GTD Manager: Gladys Hooper

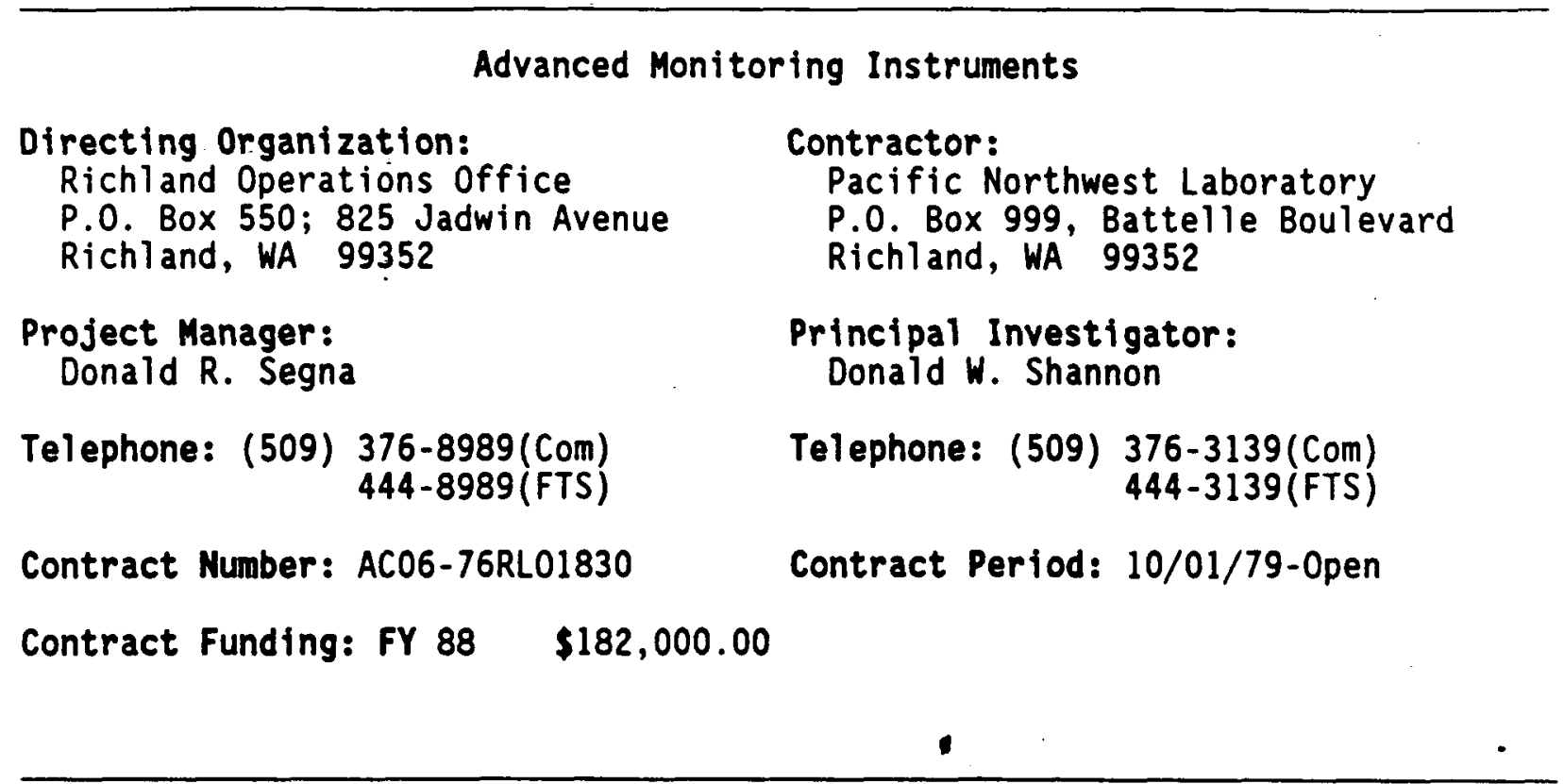

Description:

Development, testing, and application of advanced process chemistry techniques for in-line monitoring at geothermal power plants.

Activities/FY88 Milestones:

Conduct laboratory tests of prototype laser and ultrasonic particle meters using a high-temperature, high-pressure synthetic brine set-up at Pacific Northwest Laboratory prior to field tests.

Accomplishments to Date:

Developed and/or tested the following in-line monitoring instruments since the program began in 1979:

Leak detectors for brine, hydrocarbon, and cooling water systems;

Electrodeless conductivity probe to monitor brine and detect gases;

Redox meter (ORP) to detect air intrusions;

State-of-the-art $\mathrm{pH}$ meters to monitor the acidity that affects both corrosion and scaling; and

Particle counters to monitor solids that could plug injection wells.

Completed a two-year cooperative testing program with Magma Electric Company at Magma's East Mesa Binary power plant in which some serious chemical problems were detected before plant failure. 
Developed an in-line monitoring system for the Heber Binary power plant based on field monitoring experience at the East Mesa plant.

Entered into a Site Assessment Agreement with San Diego Gas and Electric Company, and carried out a host of process chemistry experiments at the Heber plant. One experiment was to use a filter test to look at scaling tendencies of the Heber plant brine if it were cooled below $150 \mathrm{~F}$.

Developed experimental data to test a geothermal brine computer model being developed by the University of California at San Diego.

Assembled and published a comprehensive handbook of brine treatment processes and other factors associated with injection well longevity.

\section{Major Reports to Date:}

Robertus, R. J., Shannon, D. W., and Sullivan, R. G. Report on "Design Construction and Testing of $\mathrm{CO} 2$ Breakout System for Geothermal Brines". PNL-5042, Pacific Northwest Laboratory, Richland, Washington, March 1984.

Robertus, R. J., Sullivan, R. G. and Shannon, D. W. "Operating Manual for Water in Hydrocarbon Leak Detector". PNL-5043, Pacific Northwest Laboratory; Richland, Wahington, April 1984.

Robertus, R. J., Shannon, D. W., Sullivan, R. G. and Pool, K. H. "Operating Manual for Hydrocarbon in Water Leak Detector". PNL- 5132, Pacific Northwest Laboratory, Richland, Washington, June 1984.

Robertus, R. J., Shannon, D. W., and Sullivan, R. G. "Special Function Instruments for Binary Cycle Geothermal Power Plants." Geothermal Resources Council Transactions, Vo1. 8, pp. 93-97, August 1984.

Robertus, R. J., Pool, K. H., Kindle, C. H., Sullivan, R. G., Shannon, D. W., and Pierce, D. D. "Leak Detectors for Organic Rankine Cycle Power Plants: On-Line and Manual Methods". PNL-5261, Pacific Northwest Laboratory, Richland, Washington, October 1984.

Robertus, R. J., Shannon, D. W., Sullivan, R. G., Kindle, C. H., and Pool, K. H. "Research on Geothermal Chemistry and Advanced Instrumentation." PNL-SA-13397. Proceedings of Fourth Annual DOE Geothermal Program Review, Washington, D.C. September 11-12, 1985.

Robertus, R. J., et al. "Field Tests of Corrosion and Chemical Sensors for Geothermal Power Plants". PNL-5782, Pacific Northwest Laboratory, Washington, March 1986.

Robertus, R. J., Sullivan, R. G., and Shannon, D. W. "Scaling Tendency of Some Moderate Temperature Geothermal Brines". PNL-5991, Pacific Northwest Laboratory, Richland, Washington, September 1986.

Pool, K. H., Raney, P.J., and Shannon, D. W., "Calcite Solubility in Simulated Geothermal Brines". PNL-6157, Pacific Northwest Laboratory, Richland, Washington, February 1987. 
Task: Conversion Technology

Project: Advanced Brine Chemistry

GTD Manager: Gladys Hooper

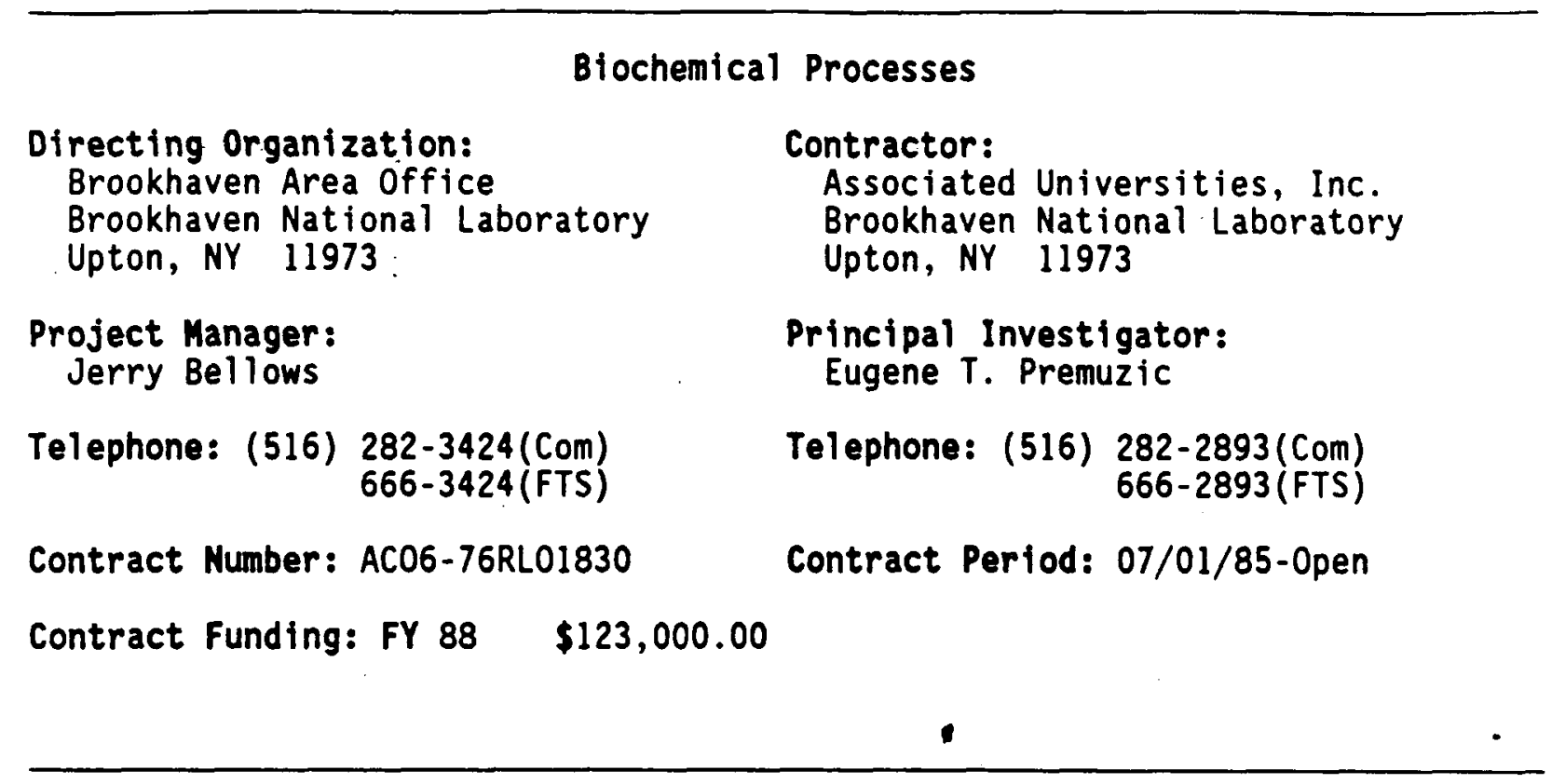

Description:

Evaluation of biochemical techniques to concentrate and remove toxic metals from geothermal wates.

Activities/FY88 Milestones:

Initiate optimization experiments using Thermophilic Bacteria.

Continue optimization experiments using Acidophilic Bacteria.

Conduct a peer-review of BNL biochemical techniques developed to date.

Issue Annual Progress Report on biochemical processes.

Accompl ishments to Date:

Conducted a detailed analyses of current geothermal waste disposal practices and regulations governing the State of California.

Demonstrated that certain micro-organisms can grow in the presence of high concentrations of toxic metals in geothermal sludge and are able to bioaccumulate heavy metals.

Successfully completed a Massachusetts Institute of Technology (MIT) Practice School Study on the economic feasibility of using biochemical processes to detoxify geothermal sludges. 
Conducted a host of laboratory experiments with various micro-organisms to evaluate the effectiveness of using different an/or mixed species to remove toxic metals such as chromium, arsenic, nickel, and lead.

\section{Major Reports to Date:}

Royce, B. "An Analysis of Environmental Regulations Governing the Disposal of Geothermal Wastes in California". BNL 37577. September 1985.

Premuzic, E. T.; Lin, M., Francis, A. J., and Subert, J. "Production of chelating agents by Pseudomonas aeruginosa grown in the presence of thorium and uranium". Proc. of the Speciation-85 Seminar, Oxford, England, April 1985, R. A. Bulman and J. R. Cooper, Editors, pp. 391-397, Elsevier, London and New York, 1986.

Premuzic, E. T., Lin, M., Zhu, H. L. and Gremme, A., "Selective absorption capacities for metals in different microorganisms". BNL 37973. Environ. Sci. and Technol. May 1986.

Dobryn, D. G., Brisson, A. L., Lee, C. M., and Roll, S.M., "Bio-leaching of toxic metals from geothermal waste, a preliminary engineering analysis".
BNL 38523, February, 1986 .

Henry, R.T., Chabria, S. P. and Lee, T. C., "Metal detoxification of aqueous waste by bioaccumulation". BNL 38778, August 1986.

Premuzic, E. T., Kwiatek, W. M., Lin, M., and Jones, K., "Regional variation in the metal composition of residual brine sludges derived from geothermal power plants". Geothermal Sci. and. Tech. BNL 38699. 1986. 
Task: $\quad$ Conversion Technology

Project: Advanced Brine Chemistry

GTD Manager: Gladys Hooper

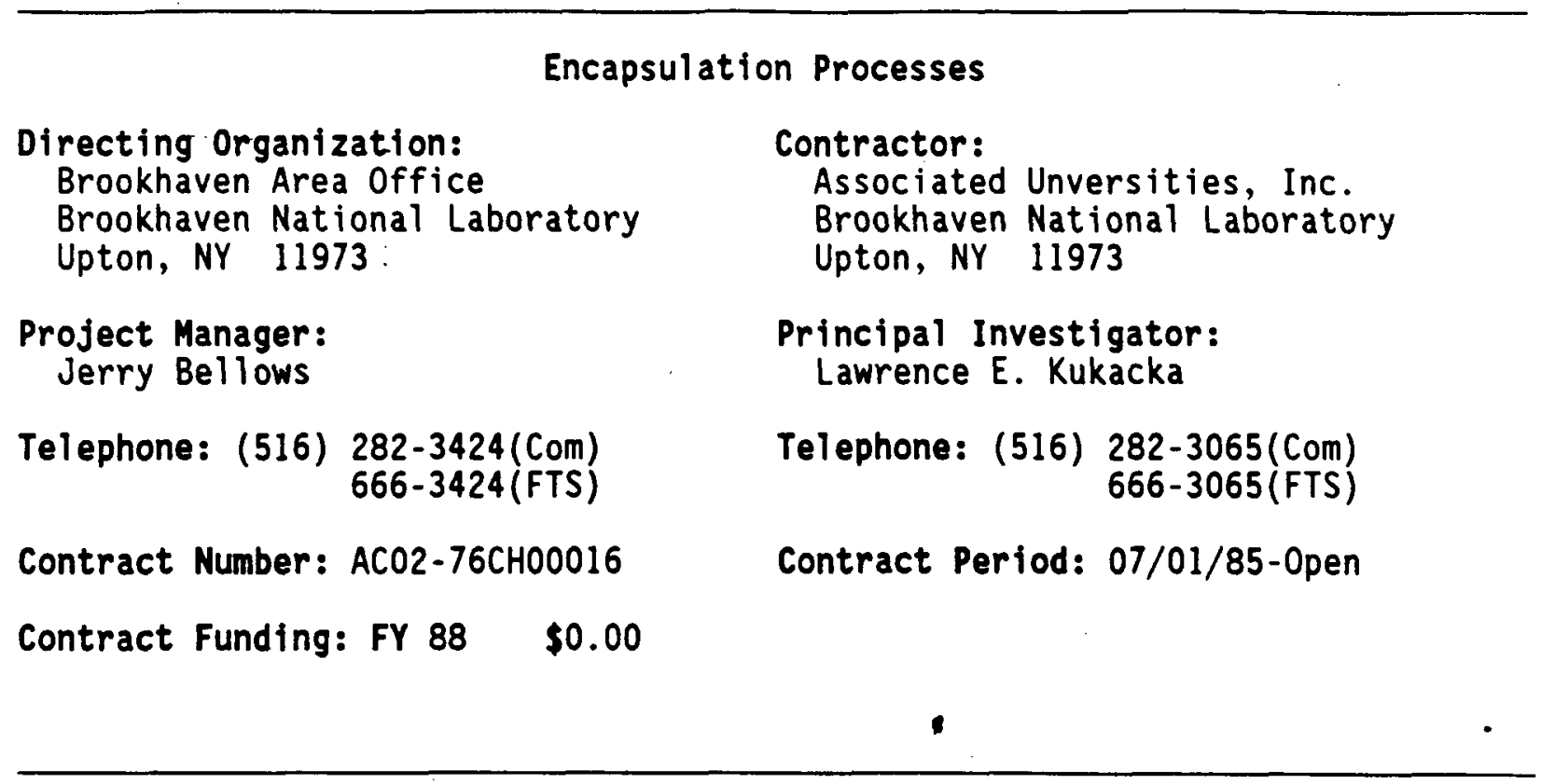

Description:

Studies of methods for utilizing waste constituents as non-leachable fillers in composites that can be used for general construction purposes.

\section{Activities/FY88 Milestones:}

Conduct preliminary experiments to determine if the silica-rich waste from the Hawaii Puna Facility can be used as a substitute for sand in a standard portland cement formulation.

Continue efforts to develop collaboration programs with industry and other governmental agencies.

\section{Accomplishments to Date:}

Established cost-shared efforts with geothermal plant operators in which brine residues from various sites in Imperial Valley, California and the Geysers were obtained.

Identified several portland cement-based mortar (PCM) and concrete (PCC) formulations containing up to $15 \%$ weight wet geothermal residues that could meet the State of $\mathrm{California}$ regulations required to classify the waste as "non-toxic".

Conducted long-term leach and property measurement tests of the new formulations, and published final results. 
Major Reports to Date:

Webster, R. P. and Kukacka, L. E. "Report on Stabilization of Geothermal Residues by Encapsulation". BNL 40384. September, 1987. 


\subsection{GeOPRESSUREd ReseARCH}

Status

Description
Long-term production tests have shown that the geopressured reservoir will produce more brine than conventional geothermal technology would predict. While this result is desirable in one sense, it is due to unknown causes, and some potential causes might result in reservoir failure despite the initial performance.

The geopressured research program is just entering the energy conversion phase. Previous field activity has centered on production testing of the wells. Some gas production occurred in conjunction with the testing but full utilization of the resource was not attempted. Now, however, the Pleasant Bayou well is being prepared for power generation experiments conducted cooperatively with the Electric Power Research Institute (EPRI). This will be the first electricity generated with geopressured brines.

The geopressured R\&D program is developing technology for estimating the size and magnitude of geopressured reservoirs and for producing and utilizing them. Tests are planned on three well operations--the Gladys McCall, the Pleasant Bayou, and the Hul in well.

The Gladys McCall in Louisiana is currently under test and has successfully produced over 27 million barrels of brine. The reservoir has proven larger than initial test data predicted, and research is concentrated on identifying reservoir drive mechanisms to help in developing improved test procedures. A comprehensive test program of variable flow rates, pressure recovery, logging, and coring is planned in the effort to understand the reservoir performance.

Testing will soon start on the Pleasant Bayou well near Houston, Texas. The DOE/EPRI hybrid electrical power generation system will be tested on this well, and work will continue to evaluate reservoir performance.

It is hoped that geopressured R\&D can be completed with the testing of the Hul in well in 1992. Technology developed on the Gladys McCall and Pleasant Bayou wells will be used to plan and predict the performance of this well. The Hul in 
well is a former gas well contributed by industry, and at 21,000 feet, it is much deeper than any other wells tested. It has the potential to be economical in the future, and will serve as a verification of the geopressured technology developed to date.

A major accomplishment of this program category was development of a successful procedure for scale control at the Gladys McCall. Prior to injection of the scale inhibitor into the reservoir, the well flow was limited to 15,000 barrels/day. With the new procedure, the well has flowed for over a year at a maximum rate. A similar treatment will be prepared for the Pleasant Bayou well.

Operators have been required at the Gladys McCall around the clock. The benign well performance indicates ful1-time operators are not required, and the Pleasant Bayou well is being instrumented for semiautomatic operation with an operator in attendance or immediately available. If this is successful, the Hul in well will be fully automated with operator requirements similar to oil and gas wells.

All geopressured production well sites have been monitored for subsidence, seismicity, and water quality. No adverse environmental effects have been detected, and it is planned to continue environmental monitoring for two to three years after well testing is completed.

The equipment to be used in the power generation experiments will incorporate both gas combustion and geothermal heat in a hybrid binary cycle. This type system can produce in excess of 15 percent more electricity than the same amount of fuel and geothermal fluid used in separate power plants. The first three months of operation will be a start-up, shakedown, and testing period. Following the intensive test, the facility is scheduled to be operated for nine months on a continuous basis. The intent of this long-term test is to evaluate system reliability and to obtain data over an extended period. 
Task: Well Operations

GTD Manager: Raymond Fortuna

Project: G.McCall/Pleasant Bayou/Hul in Reservoirs

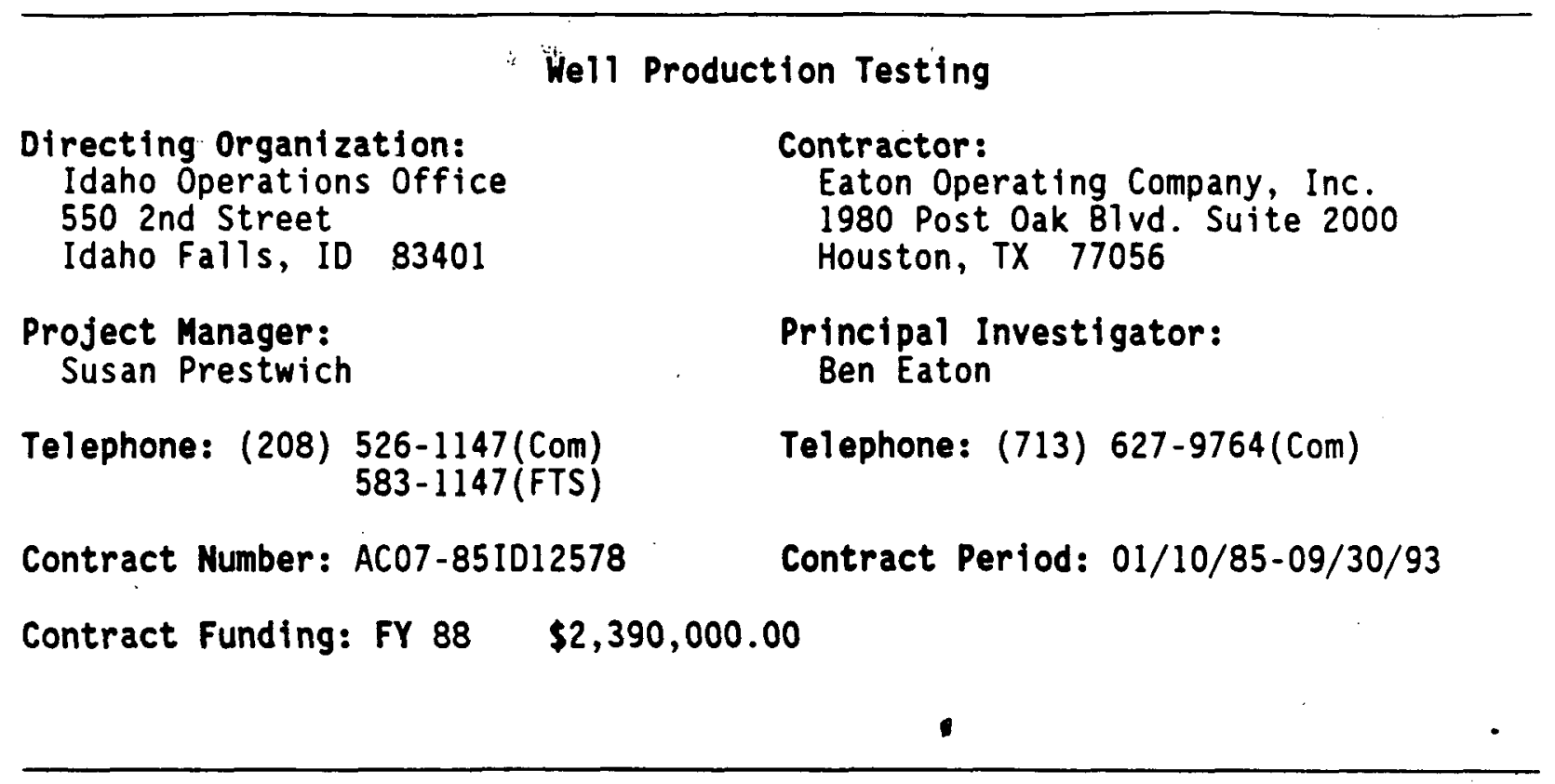

Description:

The overall objective of the geopressured research effort is to define the physical and chemical properties of the geopressured-geothermal resource, and to establish the technical feasibility of extracting and utilizing the chemical, thermal, and hydraulic energies contained in geopressured brines. As part of this objective, the well production testing project is designed to test identified geopressured-geothermal resources.

\section{Activities/FY88 Milestones:}

Shut in Gladys McCall well to monitor pressure recovery.

Install surface facilities and begin flow testing the Pleasant Bayou well.

Continue to monitor surface pressures at the Hul in well.

\section{Accomplishments to Date:} 1987.

Began long-term pressure build-up test at Gladys McCall on October 29,

\section{Major Reports to Date:}

Monthly progress reports from the Eaton Operating Company. 
Task: Geo.\& Engineering Support Project: Field Tests

GTD Manager: Raymond Fortuna

\footnotetext{
Field Testing of Geopressured Wells

Directing Organization:

Idaho Operations office 550 2nd Street

Idaho Falls, 1083401

Project Manager:

Susan Prestwich

Telephone: (208) 526-1147(Com)

583-1808(FTS)

Contract Number: AC07-85NV10412

Contract Funding: FY $88 \quad \$ 1,140,000.00$

\author{
Contractor: \\ University of Texas \\ Aust in Campus \\ Austin, TX 78712 \\ Principal Investigator: \\ Dr. Myron Darfman
}

Telephone: (512) 471-1267(Com)

Contract Period: 01/10/85-09/30/93

Description:

The objective of the research support program is to define the physical and chemical properties of geopressured-geothermal resources; monitor the environment near the well site, and archive data.

\section{Activities/FY88 Milestones:}

Continue research on subsidence, surface and ground water quality, rock mechanics, geology, well logging, reservoir analysis, and aromatic and a) iphatic hydrocarbons.

\section{Accompl ishments to Date:}

No indication of environmental effects caused by geopressured brine production.

Showed through rock mechanics work and reservoir analysis that irreversible rock compaction is not the primary pressure maintenance mechanism in the Gladys McCall reservoir.

Concluded tests that indicated that the production of aliphatic hydrocarbons is flow rate dependent.

Concluded tests that showed that the accuracy of resistivity and S\&P $10 \mathrm{~g}$ interpretations improved when the variation of the resistivity of the mud make-up water used in the well was minimized.
} 


\section{Major Reports to Date: \\ "Technical Support For Geopressured-Geothermal Well Activity In Louisiana", Louisiana State University. September 1987. \\ Monthly Progress Reports.}


Task: Energy Conversion

Project: Pieasant Bayou Hybrid Power System

GTD Manager: Raymond Fortuna

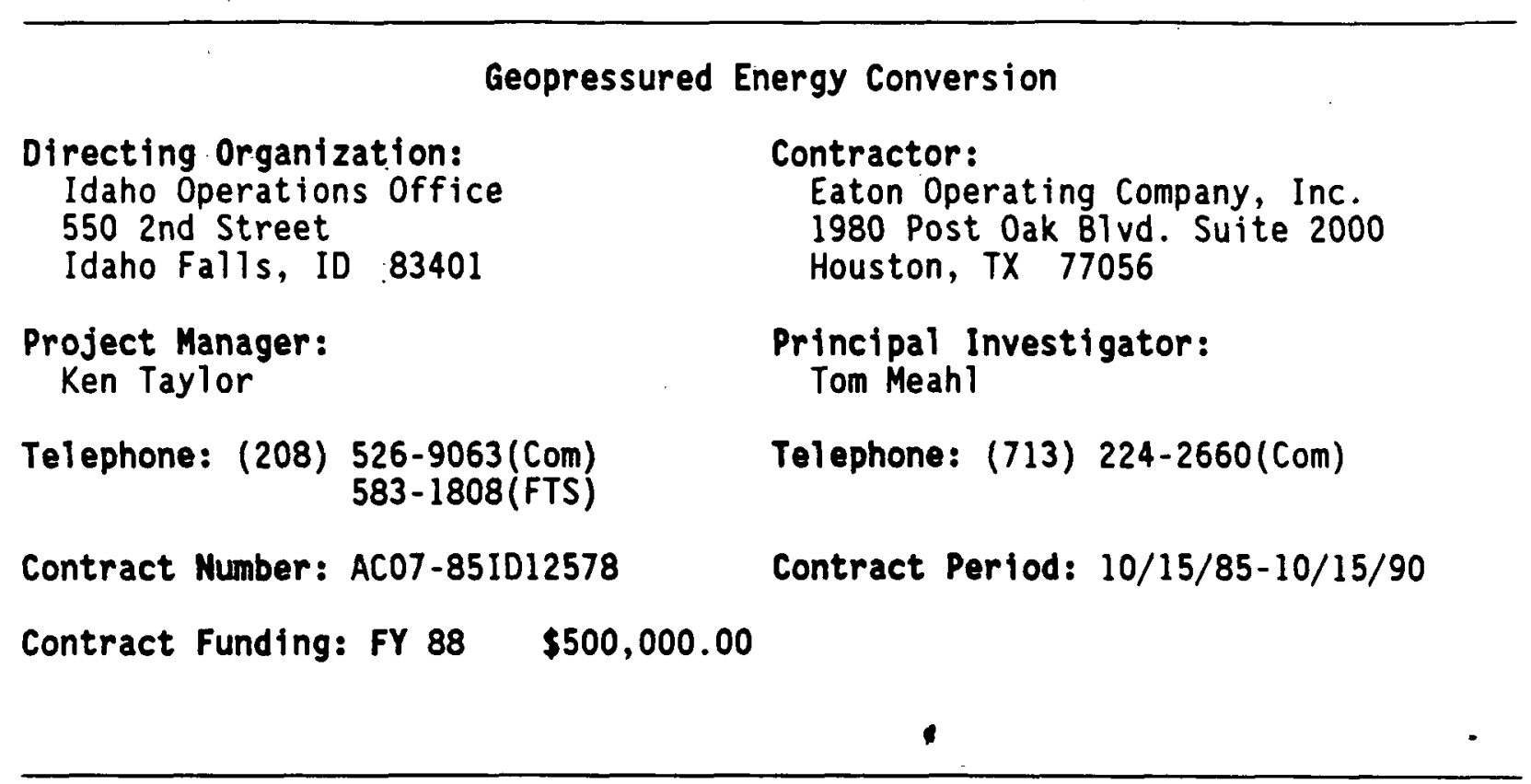

Description:

The objective of the geopressured energy conversion project is to establish the technical feasibility of generating electricity from the chemical, thermal, and hydraulic energy contained in geopressured brines.

Activities/FY88 Milestones:

Begin construction of the hybrid power system.

Complete construction of hybrid power system.

Begin operation of the hybrid power system.

Accompl ishments to Date:

Agreement with EPRI to construct and test the system in place.

Equipment on-site at Pleasant Bayou and system design completed.

Major Reports to Date:

None. 


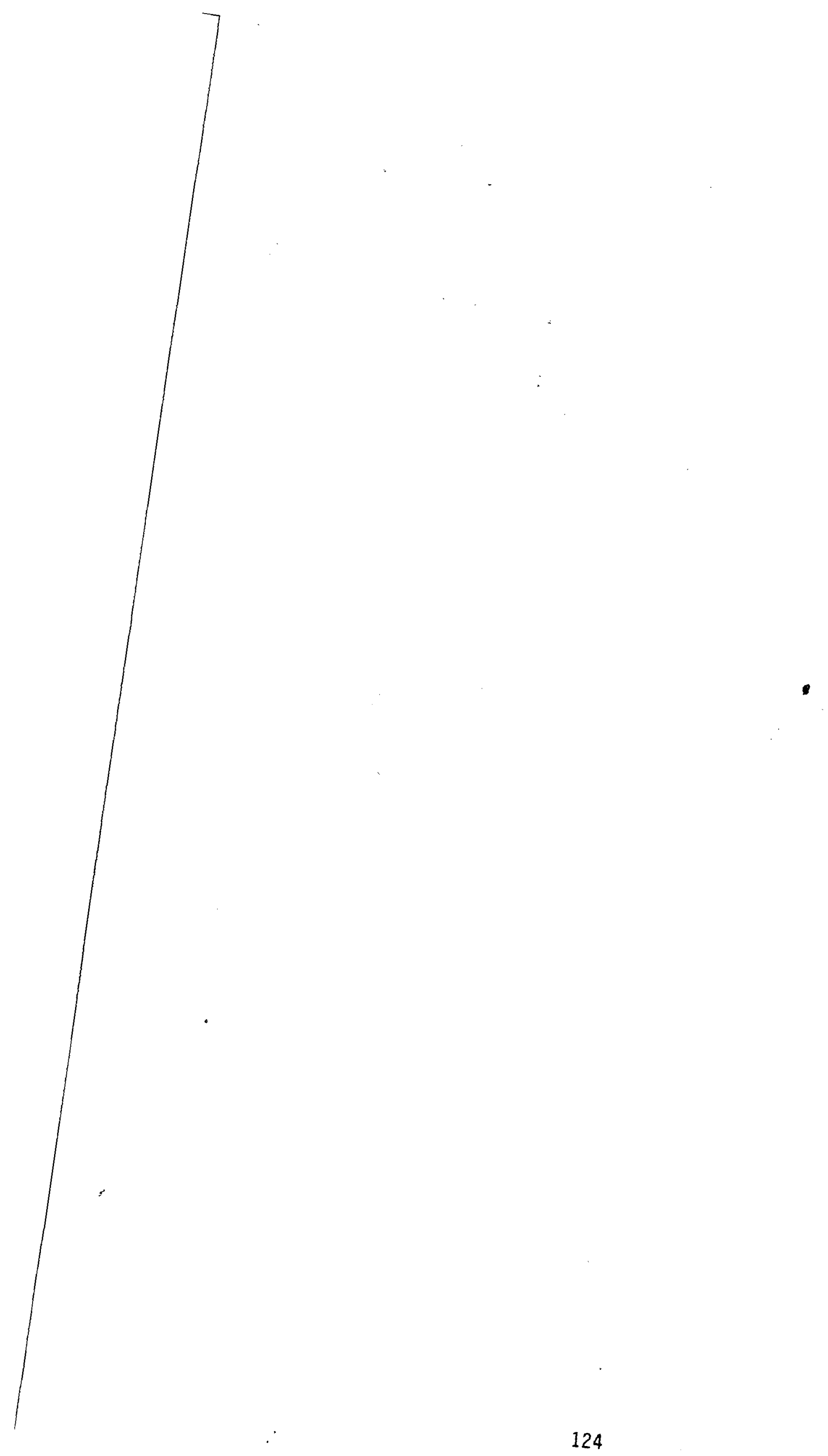




\section{SECTION 4.0 \\ HOT DRY ROCK RESEARCH}




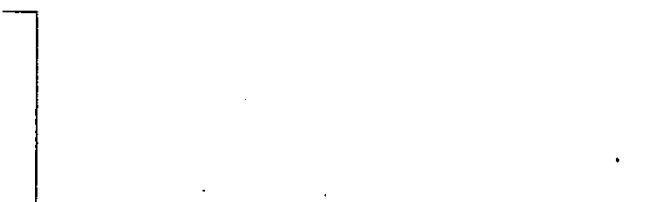

\section{.}

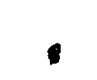

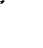

.

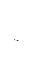




\subsection{Hot Dry Rock Research}

Status

Description
The Hot Dry Rock (HDR) resource is know to be very large, but the characteristics and limits of the resource reservoir need to be more clearly understood. More cost-effective technology for creating heat exchange fractures and completing and logging HDR wells is needed to develop more economical HDR systems.

Geothermal energy in the form of Hot Dry Rock is abundant and can be found in many states, not just a few geologically favored regions. At depths at which the formation temperatures are high enough to be commercially useful, the combination of temperature, pressure, and chemical processes usually has caused the hot dry rock to be nearly impermeable and very low in free water content. This condition is typical of hot dry rock. The HDR method for recovering heat from the earth's curst is to drill two wells and connect them through a series of cracks or fractures produced by pressurizing one of them. Water pumped down one well is heated as it circulates through the fractures and is brought to the surface through the other well under sufficient pressure to keep it from boiling. The useful heat is removed in heat exchangers, and the water is returned to recirculate and recover more heat. The removed heat can be used directIy, or converted to electricity using conventional technology.

Several years ago Los Alamos completed the world's first hot dry rock system at Fenton $\mathrm{Hill}$ in the mountains of northern New Mexico. The year-long operation brought hot water to the surface at a temperature of about $140^{\circ} \mathrm{C}\left(280^{\circ} \mathrm{F}\right)$, and at a rate such that it could have heated several hundred houses. Los Alamos has since undertaken development of a larger, deeper and hotter system. Two wells were drilled at Fenton $\mathrm{Hill}$ to depths of about $4.3 \mathrm{~km}(14,000 \mathrm{ft})$, and they were hydraulically connected by pressurizing one of them. In the largest experiment, nearly $22,000 \mathrm{~m}^{3}(6,000,000 \mathrm{gals})$ of water were pumped into the rock at a pressure of about $48 \mathrm{MPa}(7000$ lbs/in').

In May and June of 1986, Los Alamos conducted the 30-day-long Initial Closed Loop Flow 
Test in which cold water was pumped down one well through the hot fractured rock, and then returned to the surface via the other well. The goal of this initial reservoir test was to provide preliminary technical information so that a longer and final test of the system can be properly designed. This 30-day-long test met all its objectives. At the conclusion, hot water was brought to the surface at a temperature of $192^{\circ} \mathrm{C}$ $\left(375^{\circ} \mathrm{F}\right)$, and its temperature was still rising. At the end of the test, all parameters that govern successful, efficient energy extraction were improving favorably. The successful completion of this test resulted in international recognition. With this operating data in hand, Los Alamos is designing the equipment for the final, year-long Long Term Flow Test, to demonstrate the ultimate heat capability of the reservoir, and provide the design basis for commercial HDR development.

The Los Alamos HDR Program has pioneered in development of welf-logging, sampling, and downhole monitoring instruments resistant to the temperatures, pressures, and corrosive environments of geothermal wells, and in collecting and interpreting information form them. This has been essential to HDR development at Fenton Hill (and directly useful of measurements in steam, hot water, and hot 0 il and gas wells). However, much remains to be done in continued improvement of the instruments themselves, techniques for using them, transmitting the information to the surface, and analyzing and interpreting that information. An immediate need is improvement of downhole geophones, particularly with regard to their acoustic coupling to the borehole wall. Improvement of the hodogram technique for determining the source locations of those signals will be important. The hodogram method differs from conventional seismic methods of locating fractures in that only one well is needed. Conventional methods use multiple wells, which must be expensively drilled. There is an urgent need for development of a downhole stressmeasuring device, and for further improvement of the borehole televiewer.

A basic understanding of the thermal, hydraulic, and mechanical behavior of fractured HDR reservoirs will contribute greatly to successful development of geothermal energy systems in a wide variety of geologic environments. This will involve a combination of 
theoretical, laboratory, and field studies with improved computer modeling to analyze, correlate, and interpret their results. To improve the economics of HDR systems by reducing pumping costs and increasing energy production rates, further development is needed of techniques to reduce flow impedance through the fracture system by hydraulic or chemical stimulation. The ability to control the chemistry of the circulating geothermal fluid makes possible important experiments in rock-water interactions, chemical mining, scaling and plugging by mineral deposition, and the incidence, nature, and control of corrosion in geothermal systems. Particularly for energy storage, the huff-puff operating mode (a)ternate injection of cool water and production of hot water or steam) should be investigated in large-scale field experiments. 
Task: Fenton Hill Operations

GTD Manager: James E. Rannels

Project: Phase II Energy Extraction System

Energy Extraction System/Ancillary Activities/Site Support

Directing Organization:

Albuquerque Operations office

P.0. Box 5400

Albuquerque, NM 87115

Contractor:

Los Alamos National Laboratory (UC)

P.0. Box 1663

Los Alamos, NM 87545

Project Manager:

George P. Tennyson

Telephone: (505) $846-3219$ (com)

846-3219(FTS)

Principal Investigator:

Hugh Murphy

Telephone: (505) 667-7811(com)

$842-7811$ (FTS)

Contract Number:

Contract Period: 10/01/83-Open

Contract Funding: FY $88 \quad \$ 4,050,000.00$

Description:

The primary objective of the three projects under the Fenton $\mathrm{Hill}$

Operations Task is to create and control a multiple-fractured reservoir with extended longevity (20 years), and larger potential (20 to $35 \mathrm{MW}$ ).

\section{Activities/FY88 Milestones:}

Complete final repair of $\mathrm{EE}-2$ wellbore.

Side track well to interact with man-made reservoir.

Install 7-inch liner to the surface.

Begin procurement of surface equipment for the Long Term Flow Test.

\section{Accomplishments to Date:}

Completed the 30-day flow test in the reservoir.

Created a large man-made reservoir using hydraulic fracturing.

Created a large closed loop circulation system for power generation.

Major Reports to Date:

Fiscal Year 1985 Annual Report; Fiscal Year 1984 Annual Report; Fiscal Year 1983 Annual Report. 


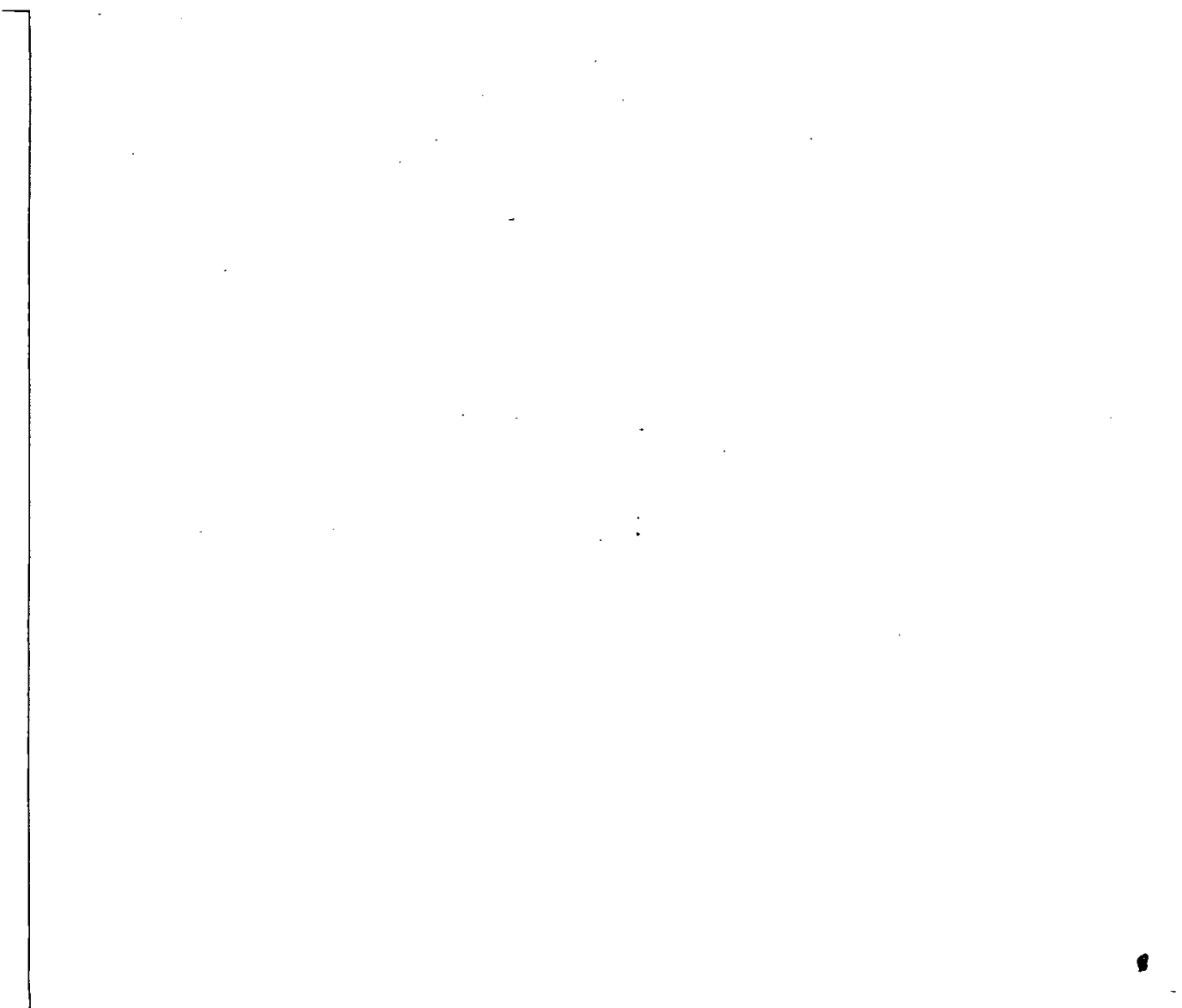


Task: Science \& Engineering Support GTD Manager: James E. Rannels Project: Instrumentation/Engineering/Applications

Tools \& Instrument./Reservoir Engin./Technology Applications

Directing Organization:

Alburquerque Operations Office

P.0. Box 5400

Alburquerque, NM : 87115

Project Manager:

George P. Tennyson

Telephone: (505) 846-3219(Com)

$846-3219$ (FTS)

Contract Number:

Contract Funding: FY $88 \$ 1,150,000.00$
Contractor:

Los Alamos National Laboratory (UC)

P.0. Box 1663

Los Alamos, NM 87545

Principal Investigator: Hugh Murphy

Telephone: (505) 667-7811(Com)

$843-7811$ (FTS)

Contract Period: 10/01/83-Open

Description:

The objectives of the project are as follows:

To provide both scheduled and unscheduled calibration and maintenance for the Fenton Hill Operations;

To develop chemical techniques for assessing the life of the reservoir, and evaluate the size of the reservoir.

Activities/FY88 Milestones:

Continue development of new techniques for microseismic analyses.

Develop chemical techniques for assessing the life of the reservoir during the Long Term Flow Test.

Accomplishments to Date:

Developed a set of high temperature-high pressure tools.

Developed microseismic techniques for estimating the size of newly created reservoirs.

Constructed a model for reservoir operations.

Major Reports to Date:

Fiscal Year 1985 Annual Report; Fiscal Year 1984 Annual Report; Fiscal Year 1983 Annual Report. 


\section{SECTION 5.0}

\section{MAGNA RESEARCH}




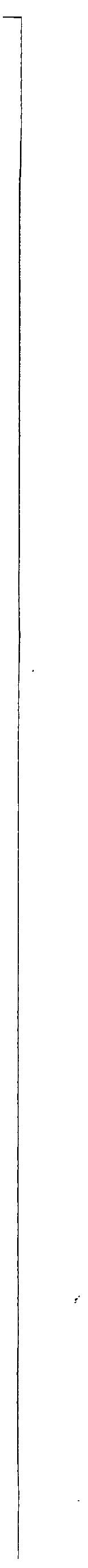

.
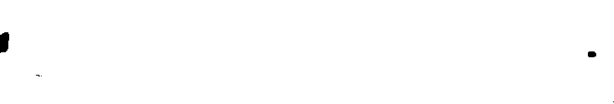

$-$ 


\subsection{Magma Research}

Status

Description
The scientific feasibility of extracting energy from molten rock has been proven by experiments at a shallow lava lake in Hawaii. The scientific and engineering technology to locate such chambers and to extract energy from them has yet to be developed and tested.

The thermal energy contained in magmatic systems represents a huge potential resource. The thrust of the magma energy extraction R\&D program is to determine the engineering feasibility of locating, accessing, and utilizing magma as a viable resource. This effort is a follow-on to the DOE/OBES-funded Magma Energy Research Project that determined the scientific feasibility of the magma energy concept.

The rate of energl extraction from magma has a direct influence on the economic viability of the concept. Therefore, ongoing research is directed at developing a fundamental understanding of the establishment and long-term operation of closed-loop and open-, direct-contact heat exchanges in a crustal magma body. An open heat exchanger, in which fluid is circulated through the interconnecting fissures and fractures in the solidified region around drilling tubing, offers the promise of very high rates of heat transfer. Studies show that an open heat exchanger can be formed by solidifying magma around a cooled borehole and that the resulting mass will be extensively fractured by thermally induced stresses. Numerical models indicate that highquality thermal energy can be delivered at the wellhead at nominal rates from 25 to 30 MWe. It is known that optimum well circulation rates can be found that depend on the heat transfer characteristics of the magma heat exchanger and the thermodynamic power conversion efficiencies of the surface plant.

Previous heat extraction experiments indicated that most magma configurations are practical for utilization at energy extraction rates that are comparable to or better than those in conventional geothermal fields. The high temperatures of the magma resource and the corresponding high temperatures of the working fluid lead directly to efficient, conventional 
techniques for generating electricity. Processes have also been considered for using this highquality energy to generate transportable fuels in addition to electricity.

A primary long-range target of this effort is to conduct an energy extraction experiment directly in a molten, crustal magma body. Critical to determining engineering feasibility are several key technology tasks: (1) to obtain detailed geophysical definition of potential magma targets; (2) to characterize the magma environment and select compatible engineering materials; (3) to develop drilling and completion techniques for entry into a magma body; and (4) to develop heat extraction technology. 
Task: Long Valley Operations

Project: Drilling and Engineering

GTD Manager: Gladys Hooper

Long Valley Well

Directing Organization:

Albuquerque Operations office

P.0. Box 5400

Albuquerque, NM 87115

Contractor:

Sandia National Laboratories

P.0. Box 5800

Albuquerque, NM 87185

Project Manager:

George P. Tennyson

Principal Investigator:

James C. Dunn

Telephone: (505) 846-3219(Com)

846-3219(FTS)

Telephone: (505) 844-4715(Com)

$844-4715$ (FTS)

Contract Number: AC04-760P00789

Contract Period: 10/20/83-0pen

Contract Funding: FY $88 \quad \$ 745,000.00$

\section{Description:}

Drill a multiphased deep observation well in the southern portion of the Long Valley Caldera to determine the nature of previously identified geophysical anomalies.

\section{Activities/FY88 Milestones:}

Establish an expert panel to:

- Assess the feasibility of drilling in the eastern moat of the Long Valley Caldera;

- Develop a scientific plan for the well

- Establish specific objectives for each drilling phase of the well.

Deliver letter of intent to the BLM and the Forest Service concerning the Long Valley Drilling project.

Select drilling engineer and drilling contractor for Long Valley Well.

Work with State and Federal agencies to obtain the necessary permits.

Spud the Long Valley Well and initiate the drilling of Phase I.

Accomplishments to Date:

Evaluated twenty-one potential magma sites in terms of suitablity for conducting a long-term energy extraction experiment. 
Selected two primary sites - Long Valley Caldera and Coso Hot Springs for more detailed evaluations and surveys.

Selected Long Valley Caldera as the best candidate site, primarly on the extensive geophysical and geological studies completed in the area.

Entered into an agreement with Santa Fe Geothermal to utilize its drill site in the southern portion of the Long Valley Caldera.

Major Reports to Date:

Hardee, H. C., "Shallow Magma Targets in the Western U.S.", Sandia National Laboratories Report SAND83-1361, Albuquerque, NM. 1984.

Carson, C. C., "Selection of Promising Sites for Magma Energy Experiments", Sandia National Laboratories Report SAND84-2171, Albuquerque, NM. 1985. 
Task: Long Valley Operations

Project: Supporting Science

GTD Manager: Gladys Hooper

\section{Geophysics}

Directing Organization:

Albuquerque Operations Office

P.0. Box 5400

Albuquerque, NM 87115

Project Manager:

George P. Tennyson

Telephone: (505) 846-3219(Com)

846-3219(FTS)

Contract Number: ACO4-76DP00789

Contractor:

Sandia National Laboratories

P.0. Box 5800

Albuquerque, NM 87185

Principal Investigator:

James C. Dunn

Telephone: (505) 844-4715(Com)

$844-4715$ (FTS)

Contract Period: 10/20/83-0pen

Contract Funding: FY $88 \quad \$ 75,000.00$

Description:

The objective of the Geophysics project is to ensure that sufficient and accurate geophysical and geoscience measurements are carried out in conjunction with the drilling of the observation well.

Activities/FY88 Milestones:

Develop a scientific plan for geoscience measurements in the Long Valley Well at each drilling stage in conjunction with universities, national laboratories, and industry.

Accomplishments to Date:

Establish a magma energy science comnttee to develop a detailed science plan for the various stages of the observation well.

Major Reports to Date:

Rundle, J. B., et al, "Seismic Imaging in Long Valley, California, by Surface and Borehole Techniques: An Investigation of Active Tectonics", EOS V. $66, n 18,1985$.

Rundle, J. B., Carrigan, Hardee, and Luth. "Deep Orilling to the Magmatic Environment in Long Valley Caldera", EOS, V. 67, n 21, 1986.

Elbring, G. J., and Rundle, J. B., "Analysis of Borehole Seismograms from Long Valley, California: Implications for Caldera Structure", J. of Geophys. Res., V. 91, n B12, 1986. 


\section{Geochemistry/Materials}

Directing Organization:

Albuquerque Operations office P.0. Box 5400

Albuquerque, NM 87115

Project Manager:

George P. Tennyson

Telephone: (505) 846-3219(Com)

$846-3219$ (FTS)

Contract Number: ACO4-760P00789

Contract Funding: FY $88 \quad \$ 200,000.00$
Contractor:

Sandia National Laboratories P.0. Box 5800

Albuquerque, NM 87185

Principal Investigator: James C. Dunn

Telephone: (505) 844-4715(Com) $844-4715$ (FTS)

Contract Period: 10/20/83-Open

Description:

The objective of the Geochemistry/Materials project is to conduct experiments aimed at characterizing magma at the primary site and defining its 'compatibility' with commercially available materials.

Activities/FY88 Milestones:

Experimentally determine importance of several mechanisms, (pH, solution composition, mineral defects), on Feldspar dissolution in aqueous solutions.

Measure quartz dissolution as a function of temperature, pressure, and orientation using rotating disc autoclaves.

\section{Accomplishments to Date:}

Evaluated 17 comercially available materials and determined that nickel, iron, and cobalt-based super alloys have very good chemical resistance and strengths in a rhyolitic magma environment.

Compositions of the Long Valley and Coso magma chambers were estimated from analyses of rhyolite giass at the surface.

Volatile concentrations were obtained by analyzing glass inclusions in rapidly quenched tephra.

An experimental procedure for testing magma/metal compatibility was developed. 
Major Reports to Date:

Westrich, H. R., Weirick, Cygan, Reece, Hlava, Stockman, and Gerlach. "FY1984 and FY1985 Geochemistry and Materials Studies in Support of the Magma Energy Extraction Program", Sandia National Laboratories Report SAND85-2843, Albuquerque, NM, 1986. 


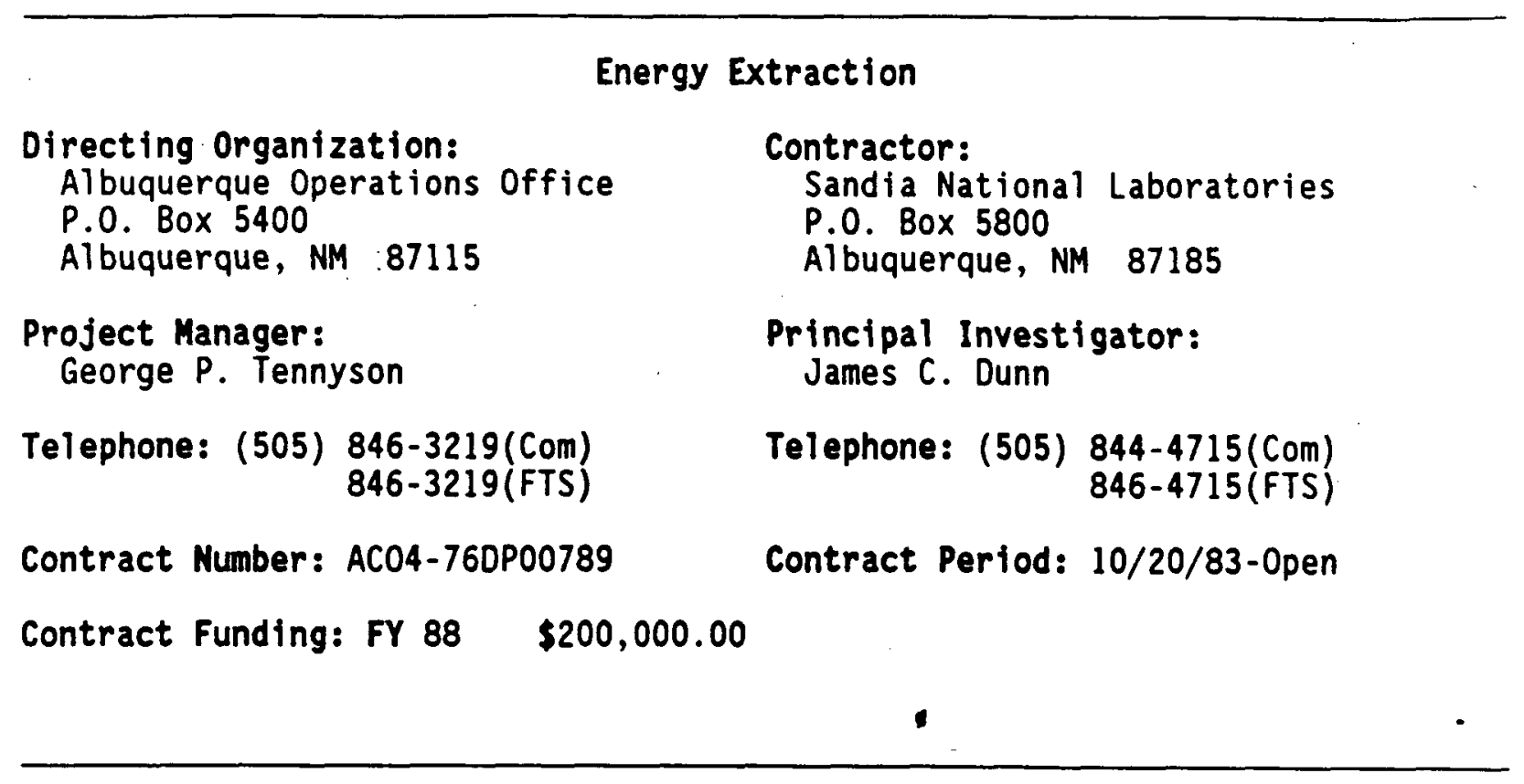

\section{Description:}

The objective of the Energy Extraction project is to formulate methodology for the efficient extraction of energy from magma by conducting system studies and experiments.

\section{Activities/FY88 Milestones:}

Measure nucleation rates for experimentally vesiculated glasses.

Report initial results of thermodynamic power cycle analysis.

Complete basic magma chamber convection experiment.

Report results of secondary fracturing experiments.

Complete direct contact heat exchanger experiments at Univ. of Utah.

\section{Accomplishments to Date:}

Conducted a series of system analyses to evaluate the economics of magma power generation.

Numerical simulation of an energy extraction process completed using a simplified mathematical model of open and closed extraction systems.

Fracturing experiments were initiated to provide qualitative fracturing behavior and thermal stress fracturing data for validation of analytical models; and for reproducing the conditions of cooling with phase change that occur in magma. 


\section{Major Reports to Date:}

Dunn, J. C., "Energy Extraction from Crustal Magma Bodies", ASME/JSME Thermal Engineering Joint Conference Proceedings, V. II. 


\section{APPENDIX A}

\section{GEOTHERMAL R\&D PROGRAM \\ PARTICIPANTS}





\section{DOE HEADQUARTERS}

\section{U.S. Department of Energy CE-324 Room 5F067

\section{Office of Renewable Energy}

Robert L. San Martin

9275

8084

Ronald R. Loose

Director, Geothermal Technology

John E. Mock

5340

Allan J. Jelacic

6054

David B. Lombard

4952

Raiph E. Burr

5335

Raymond Fortuna

1711

Gladys Hooper

1146

Raymond J. LaSala

4198

Lew W. Pratsch

1512

James E. Rannels

8070

Marshall Reed

8076

Deputy Assistant Secretary for Conservation and Renewable Energy

Director, Office of Renewable Energy Technologies Division

Team Leader, Geothermal Geosciences Research

Team Leader, Geotherma1 Conversion Research

Manager, Geothermal Loan Guaranty Program, Technology Transfer

Manager, Geopressured Resources

Manager, Advanced Brine Chemistry, Instrumentation, Magma Energy Extraction

Manager, Heat Cycle Research, Materials

Manager, Hard Rock Penetration Research

Manager, Hot Dry Rock

Manager, Hydrothermal Reservoir Research, Brine Injection Technology 


\section{DOE OPERATIONS OFFICES (WITH GEOTHERMAL PROGRAMS)}

$\begin{array}{lll}\text { George Tennyson } & \begin{array}{l}\text { U.S. Department of Energy } \\ \text { Aibuquerque Operations Office } \\ \text { P.O. Box } 5400\end{array} & \begin{array}{l}\text { Senior Program } \\ \text { Manager }\end{array} \\ \text { Aibuquerque, NM } 87115 & \\ \text { (505) } 846-3219 & \\ \text { Peggy Brookshier } & \text { U.S. Department of Energy } & \\ & \text { Idaho Operations Office } & \\ & 5502 \text { 2nd Street } & \text { Geothermal Project } \\ \text { Idaho Fal1s, ID } 83401 & \\ \text { (208) } 526-1403 & \end{array}$

\section{NATIONAL LABORATORIES (GEOTHERMAL RESEARCH)}

\begin{tabular}{|c|c|c|}
\hline Larry Kukacka & $\begin{array}{l}\text { Brookhaven National Laboratory } \\
\text { Upton, NY } 11973 \\
(516) 282-3065\end{array}$ & $\begin{array}{l}\text { Advanced Materials } \\
\text { Research }\end{array}$ \\
\hline Marcelo Lippman & $\begin{array}{l}\text { University of California } \\
\text { Lawrence Berkeley Laboratory } \\
\text { Berkeley, CA } 94720 \\
\text { (415) } 486-5035\end{array}$ & Reservoir Research \\
\hline John Whetten & $\begin{array}{l}\text { University of Cal ifornia } \\
\text { Los Alamos National Laboratory } \\
\text { P.0. Box } 1663 \\
\text { Los Alamos, NM } 87545 \\
(505) 667-6722\end{array}$ & $\begin{array}{l}\text { Hot Dry Rock } \\
\text { Research }\end{array}$ \\
\hline James Dunn & $\begin{array}{l}\text { Sandia National Laboratories } \\
\text { P.0. Box } 5800 \\
\text { Aibuquerque, NM } 87185 \\
(505) 844-4715\end{array}$ & $\begin{array}{l}\text { Geothermal Drilling } \\
\text { Organization, Hard } \\
\text { Rock Penetration, } \\
\text { Permeability En- } \\
\text { hancement, Magma } \\
\text { Resources }\end{array}$ \\
\hline Susan Steiger & $\begin{array}{l}\text { Idaho National Engineering } \\
\text { Laboratory } \\
\text { P.O. Box } 1625 \\
\text { Idaho Falls, ID } 83415\end{array}$ & $\begin{array}{l}\text { Geopressured } \\
\text { Resources }\end{array}$ \\
\hline Jud Whitbeck & (208) 528-1879 & Energy Conversion \\
\hline
\end{tabular}




\section{SUBCONTRACTORS}

\section{Universities}

Stanford University

Massachusetts Institute of Technology (MIT)

Louisiana State University (LSU)

University of Southwestern Louisiana (USL)

University of Texas at Austin (UTA)

Pennsylvania State University

North Carolina Agricultural and Technical State University (NCA\&T) San Diego State University (SDSU)

\section{Private Contractors}

- Meridian Corporation

- Oregon Institue of Technology (OIT) 


\section{APPENDIX B}

\section{PROJECTS BY TASK NAMES}




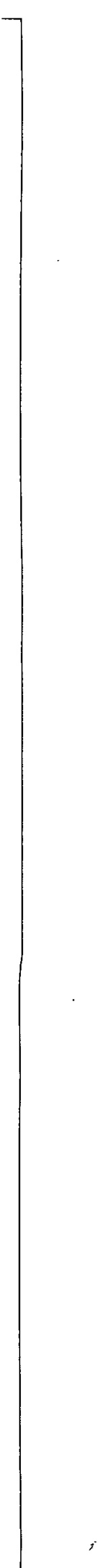

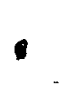$$
\text { B-2 }
$$

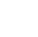

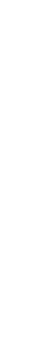


PROJECTS BY TASK NAMES

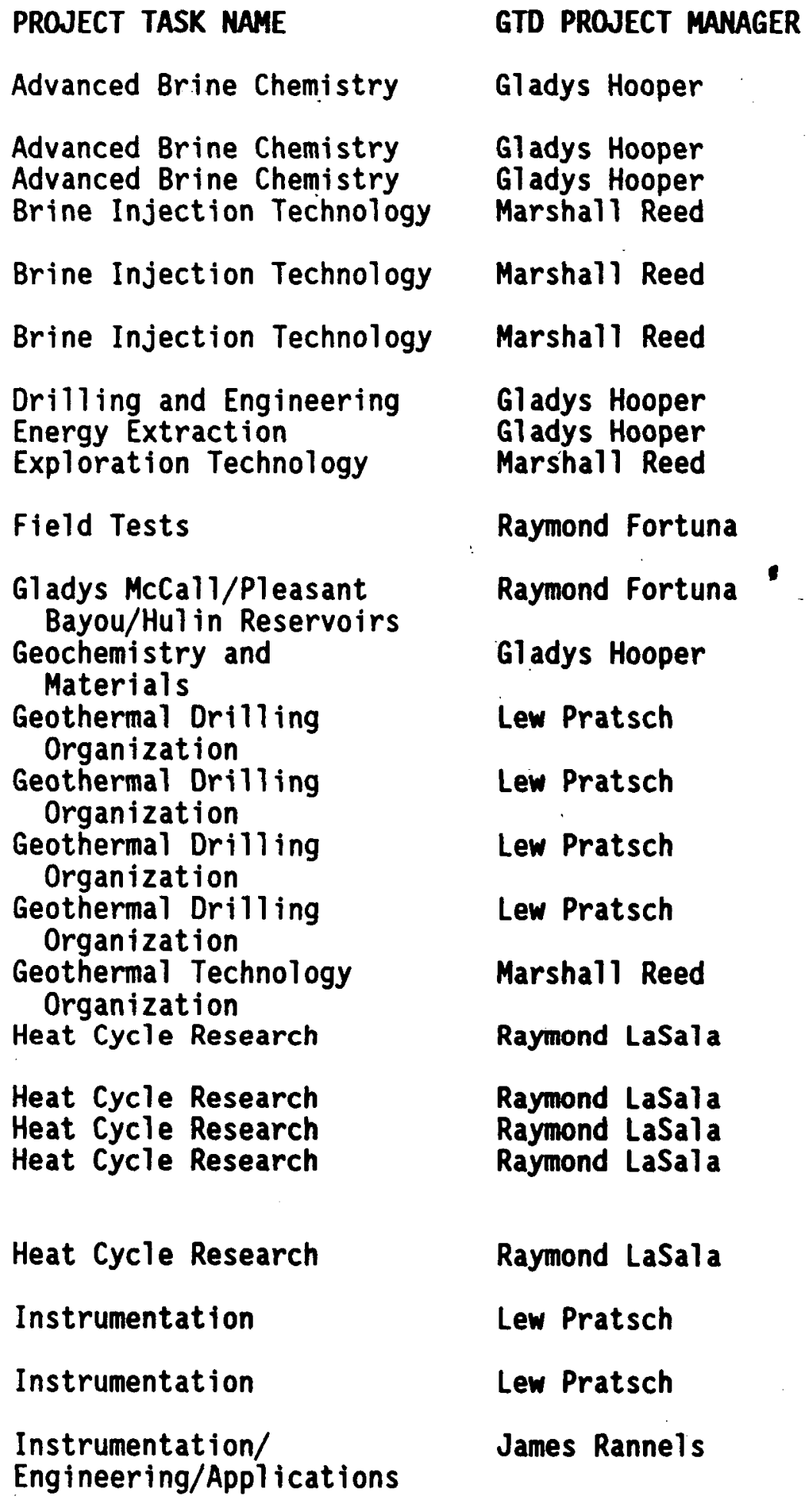

\section{PROJECT TITLE}

Advanced Monitoring Instruments

Biochemical Processes

Encapsulation Processes

Tracer Development and Interpretation

Geophysical Methods for Injection Monitoring

Modeling Injected Fluid Migration

Long Valley Well

Energy Extraction

Geophysical Methods to Locate Reservoirs

Field Testing of Geopressured Wells Well Production Testing

Geochemistry/Materials

Borehole Televiewer

Foam Lost Circulation Tool

Downhole Air Turbine

High Temperature Elastomer Development

Cooperative Research

Heat Cycle Research Facility Testing System Analysis

Condenser Attitude Tests

Metastable

Supersaturated Expansion

Advanced Heat

Rejection System

Radar Fracture Mapping Tool

Acoustical Data

Telemetry

Tools \& Instrumentation/ Reservoir Engineering/ Technology Applications 


\begin{tabular}{ll} 
PROJECT TASK NAME & GTD PROJECT MANAGER \\
Lost Circulation Control & Lew Pratsch \\
Lost Circulation Control & Lew Pratsch \\
Materials Research & Raymond LaSala \\
Materials Research : & Raymond LaSala \\
Materials Research & Raymond LaSala \\
& \\
Materials Research & Raymond LaSala \\
Phase II Energy Extraction & James Rannels \\
System & \\
Pleasant Bayou Hybrid & \\
Power System & Raymond Fortuna \\
Reservoir Analysis & Marshall Reed \\
Reservoir Analysis & Marshall Reed \\
Reservoir Analysis & Marshall Reed \\
Rock Penetration Mechanics & Lew Pratsch \\
Rock Penetration Mechanics & Lew Pratsch \\
Rock Penetration Mechanics & Lew Pratsch \\
Rock Penetration Mechanics & Lew Pratsch \\
Supporting Science & Gladys Hooper \\
\hline &
\end{tabular}

PROJECT TITLE

Lost Circulation Analysis

Lost Circulation Testing

Advanced High Temperature Cements

Non-Metall ic Heat Exchanger Tubing

Chemical Systems for Lost-Circulation Control

Very High Temperature Well Completion Materials

Energy Extraction System/Ancillary Activities/Site Support

Geopressured Energy . Conversion

Fracture Detection and Mapping

Identification of Reservoir Processes

Predictive Modeling of Reservoir Behavior

PDC Bit Development

High Temperature Drilling

Analysis of Drill String Dynamics

Coring Technology Development

Geophysics 